HÉLIO JUNJI SHIMOZAKO

\title{
Otimização da técnica de captura-recaptura fotográfica para estimação da população canina livre em vias públicas
}

Dissertação apresentada à Faculdade de Medicina da Universidade de São Paulo para obtenção do título de Mestre em Ciências.

Área de concentração: Fisiopatologia Experimental Orientador: Prof. Dr. Eduardo Massad 
"O mais nobre prazer é a alegria de compreender" Leonardo da Vinci

"A imaginação é mais importante do que o conhecimento" Albert Einstein

"A coisa mais bela que podemos experimentar é o mistério. Essa é a fonte de toda a arte e ciências verdadeiras"

Albert Einstein 
Dedico este trabalho à minha mãe, Satiko Shimozako. 


\section{Agradecimentos}

Em primeiro lugar, quero deixar registrada a minha gratidão pela minha mãe, Satiko Shimosako, por estar sempre ao meu lado, seja nos momentos de felicidade e de tristeza, e ao Prof. Dr. Eduardo Massad, por toda a atenção, paciência e orientação dada a mim, mas principalmente pela amizade adquirida.

Também sou grato:

- à todos os voluntários que se dispuseram a contribuir para com esta pesquisa.

- ao Dr. Euro de Barros Couto Júnior e ao Prof. Dr. Paulo Sérgio Panse Silveira, por toda a ajuda prestada, sem o qual este trabalho não seria possível.

- à Li Men Zhao e à minha família, por todo o apoio recebido durante e período de execução deste trabalho.

- a todos os meus companheiros da Disciplina de Informática Medida (em especial: Vilma Aparecida Duarte Sanchez, Jorge Fausto, Iracene Aparecidda Boccia, Sandra Fabiana de Almeida, Paulo César Costa dos Santos, Edna Pinto Pereira de Souza, Lêuda Oliver, Marcelo Rossi, Márcia Perez Resende Oliveros, Harki Tanaka) pela troca de experiências e pela amizade.

- aos docentes da Disciplina de Informática Médica, em especial ao Prof. Dr. Luiz Fernandes Lopez e Profa. Dra. Neli Regina Siqueira Ortega.

- também ao Prof. Dr. Marcos Amaku e ao Prof. Dr. Sérgio Rosso, pelas sugestões e críticas importantes a este trabalho.

- aos meus amigos Fábio Moraes Francisco, Patrícia Miyuki Ohara; Márcio Mustafá Araújo, Marcia Lozano e José Ribamar dos Santos Ferreira Júnior.

- à Prefeitura do Município de São Paulo (em especial ao Centro de Controle de Zoonoses) e à Prefeitura da Estância Turística de Ibiúna (em especial ao Centro de Vigilância Sanitária e Zoonoses), pela supervisão dada a este trabalho.

- à Fundação Faculdade de Medicina.

À todos que participaram direta e indiretamente no desenvolvimento e na conclusão desta pesquisa. 


\section{Normalização adotada}

Esta dissertação está de acordo com:

- Referências: adaptado de Internacional Committeee of Medical Journals Editors (Vancouver).

- Universidade de São Paulo. Faculdade de Medicina. Serviço de Biblioteca e Documentação. Guia de apresentação de dissertações teses e monografias. Elaborado por Anneliese Carneiro da Cunha, Maria Julia de A. L. Freddi, Maria F. Crestana, Marinalva de Souza Aragão, Suely Campos Cardoso, Valéria Vilhena. São Paulo: Serviço de Biblioteca e Documentação; 2005.

- Abreviatura dos títulos dos periódicos de acordo com List of Journals Indexed in Index Medicus. 


\section{Sumário}

Lista de siglas

Lista de figuras

Lista de quadros

Lista de tabelas

Resumo

Summary

1 INTRODUÇÃO

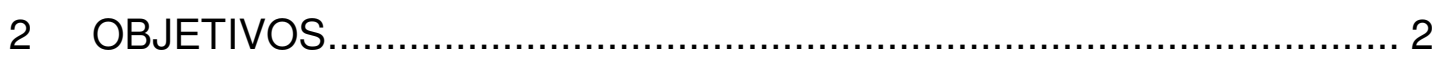

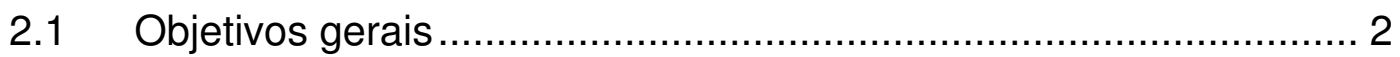

2.2 Objetivos específicos............................................................ 2

3 REVISÃO DE LITERATURA...................................................... 3

3.1 Seres humanos e cães: o processo de domesticação …………..... 3

3.2 Seres humanos como proprietários dos cães............................... 5

3.3 Os problemas causados pela população canina livre nas vias

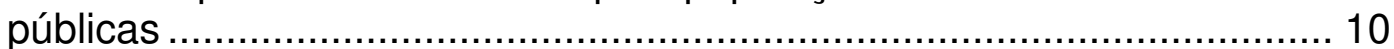

3.4 A dinâmica da população de cães nas vias públicas..................... 16

3.5 Importância de dados epidemiológicos......................................... 21

3.6 A saúde pública veterinária …………………....................... 25

3.7 O Bem-estar Animal .......................................................... 28

3.8 O método de captura-recaptura ............................................... 29

3.9 Métodos de controle populacional .............................................. 37

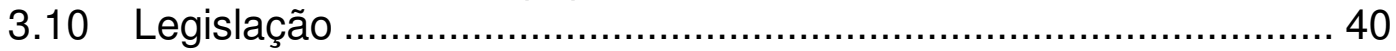

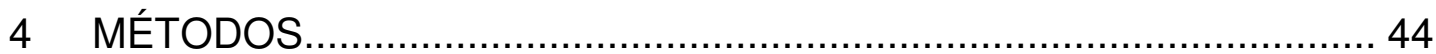

4.1 Criação dos catálogos fotográficos experimentais ....................... 44

4.2 Levantamento dos dados a campo no município de lbiúna: criação dos catálogos fotográficos obtidos em campo....................................... 50 4.3 Participação de voluntários para a identificação dos cães por meio da observação dos catálogos.......................................................... 58

4.3.1 Observação dos catálogos de fotografias dos cães do CCZ.. 59

4.3.2 Observação do catálogo de fotografias dos cães fotografados

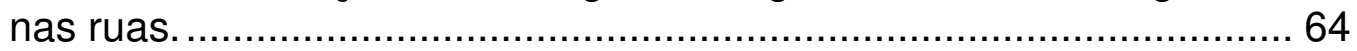

4.3.3 Disponibilização do questionário e convite aos voluntários para

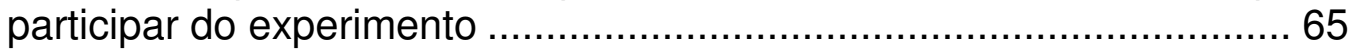

4.3.4 Erros grosseiros e filtragem de voluntários .......................... 69

4.4 Análise e interpretação dos dados obtidos a partir dos resultados do

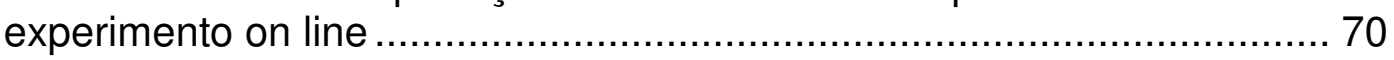

4.4.1 Observação das fotografias de cães do CCZ ......................... 70

4.4.2 Avaliação da probabilidade de identificação utilizando fotografias obtidas nas ruas. 
4.5 Estimativa da população do bairro de Santa Lúcia seguindo o método clássico: estimador de Pettersen, estimador de Chapman e Método de Beck

4.5.1 Considerando cada período como amostras independentes:

ótica do pesquisador.

4.5.2 Considerando cada dia como amostras independentes: ótica do pesquisador

5 RESULTADOS

5.1 Resultados do experimento "on line" ................................... 81

5.1.1 Observação das fotografias de cães do CCZ ...................... 81

5.1.2 Observação das fotografias de cães obtidas nas ruas ........... 83

5.2 Estimação da população canina livre nas ruas do bairro de Santa Lúcia 84

5.2.1 Considerando cada período como amostras individuais: ótica do pesquisador

5.2.2 Considerando os dias como amostras individuais: ótica do pesquisador

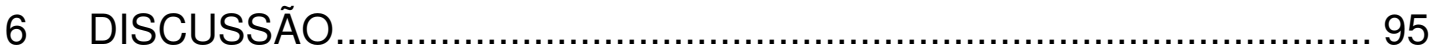

6.1 Observação das fotografias de cães do CCZ .............................. 95

6.2 Observação das fotografias de cães obtidas a campo ................ 101

6.3 Utilização do método de captura-recaptura fotográfica no bairro de

Santa Lúcia (Ibiúna / SP)................................................................. 105

6.4 Estimativas populacionais para a população canina diante de diversas configurações.

6.5 Sobre o método de avaliação e otimização apresentado neste trabalho

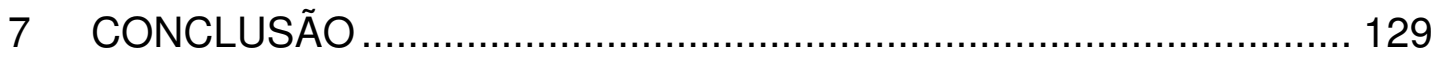

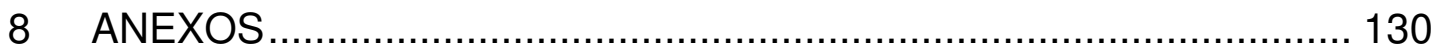

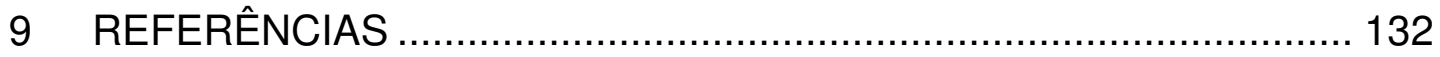

Apêndice 


\section{Lista de siglas}

$\mathrm{CCZ}$

Centro de Controle de Zoonoses

IBGE.

Instituto Brasileiro de Geografia e Estatística

SERLA.

Serviço de Regularização de Loteamento e Arruamento da Prefeitura da Estância Turística de lbiúna

WHO

World Health Organization

(Organização Mundial da Saúde)

WSPA.

World Society for the Protection of Animals

(Sociedade Mundial pela Proteção dos Animais) 


\section{Lista de figuras}

Figura 1: Diagrama de Venn e tabela de contingência relativos a um processo de captura-recaptura envolvendo duas fontes (Fonte:

Coeli et al., 2000).

Figura 2: Exemplo de um conjunto de fotos do catálogo A................... 47

Figura 3: Exemplo de um conjunto de fotos do catálogo B..................... 47

Figura 4: Exemplo de um conjunto de fotos do catálogo C................... 48

Figura 5: Exemplo de um conjunto de fotos do catálogo D.................... 49

Figura 6: Bairro Conjunto Habitacional Santa Lúcia (Ibiúna/SP)............. 51

Figura 7: Fotos ilustrativas do bairro Conjunto Habitacional Santa Lúcia (Ibiúna/SP).

Figura 8: Apresentação esquemática da sistemática de apresentação de pares e de não pares de conjunto de fotos aos voluntários

Figura 9: "Layout" do questionário "on line" utilizado neste trabalho. Nesse exemplo, foram apresentados dois conjuntos de fotos de cães internados no CCZ

Figura 10: "Layout" do questionário "on line" utilizado neste trabalho.

Nesse exemplo, foram apresentados dois conjuntos de fotos obtidos em trabalho de campo de um mesmo

encontro

Figura 11: Representação do número de animais novos e os previamente capturados (com e sem correções) por período, além da referida linha de tendência para os seis pontos (períodos amostrados).

Figura 12: Representação do número de animais novos e os previamente capturados (com e sem correções) por dia, além da referida linha de tendência para os três pontos (dias amostrados)

Figura 13: Flagrante de cão solto nas ruas entrando em residências durante o levantamento de dados no bairro de Santa Lúcia. Este cão conseguiu escalar o portão da residência para ter acesso às ruas.

Figura 14: Flagrante de cão solto nas ruas entrando em residências durante o levantamento de dados no bairro de Santa Lúcia. Este cão teve acesso às ruas por meio de um vão entre o chão e o portão da residência. 


\section{Listas de quadros}

Quadro 1: Efeitos benéficos dos animais de estimação (Bahr; Morais, 2001)

Quadro 2: Apresentação esquemática da organização das fotos obtidas experimentalmente a partir dos cães do CCZ.

Quadro 3: Apresentação esquemática da organização das fotos obtidas da amostragem realizada a campo.

Quadro 4: Diagrama gerado a partir dos resultados da avaliação dos voluntários para a observação de conjunto de pares e de não pares de conjunto de fotos do CCZ.

Quadro 5: Diagrama de resultados esperados gerado a partir dos resultados marginais da avaliação dos voluntários para a observação de conjunto de pares e de não pares de conjunto de fotos do CCZ.

Quadro 6: Diagrama representando a relação entre a estimativa de pares e de não pares assinalados pelo pesquisador e seus valores corrigidos.

Quadro 7: Codificação e identificação dos períodos amostrados. 


\section{Lista de tabelas}

Tabela 1: Razões cão:homem para diversas localidades

Tabela 2: Posição geográfica aproximada dos limites norte, sul, leste e oeste do Bairro Conjunto Habitacional Santa Lúcia (Ibiúna/SP)

Tabela 3: Exemplo de configuração de histórico de buscas para 3 momentos de amostragem.

Tabela 4: Diagrama dos resultados gerais da avaliação dos pares de conjunto de fotos dos cães do CCZ pelos voluntários. Diagramas de resultados observados e esperados representando os resultados antes da exclusão de 12 voluntários.

Tabela 5: Diagrama dos resultados gerais da avaliação dos pares de conjunto de fotos dos cães do CCZ pelos voluntários. Diagramas de resultados observados e esperados representando os resultados após a exclusão de 12 voluntários.

Tabela 6: Diagrama dos resultados gerais da avaliação dos pares de conjunto de fotos dos cães do CCZ pelos voluntários. Valores dos parâmetros calculados a partir das duas situações antes e após exclusão de 12 voluntários (Tabelas 4 e 5).

Tabela 7: Número de cães que apresentaram determinado histórico de encontro durante os seis períodos de amostragem.

Tabela 8: Estimativa da população para cada uma das 15 combinações de períodos, considerando a ótica do pesquisador

Tabela 9: Estimativa da população de cães livres nas vias públicas com base no estimador descrito pelo Método de Beck (WHO e WSPA, 1990)

Tabela 10: Número de animais novos e previamente amostrados por período amostrado.

Tabela 11: Valores de p para o teste para variâncias iguais (teste F) e a Prova U de Mann Whithney.....

Tabela 12: Número de animais distintos encontrados por dia após a unificação dos dois períodos de amostragem realizadas em cada dia.

Tabela 13: Número de cães que apresentaram determinado histórico de encontro durante os três dias de amostragem. 
Tabela 14: Estimativa da população de cães livres nas vias públicas com base no estimador de Pettersen (Nc) e de Chapman (Nc) (White et al., 1982; Amstrup et al., 2005)

Tabela 15: Estimativa da população de cães livres nas vias públicas com base no estimador descrito pelo Método de Beck (WHO e WSPA, 1990)

Tabela 16: Número de animais novos e previamente amostrados por dia amostrado

Tabela 17: Tamanho da população de cães soltos no bairro de Santa Lucia segundo os estimadores utilizados e o respectivo intervalo de confiança $95 \%$. 


\section{Resumo}

Shimozako HJ. Otimização da técnica de captura-recaptura fotográfica para estimação da população canina livre em vias públicas [dissertação]. São Paulo: Faculdade de Medicina, Universidade de São Paulo; 2008.

Embora os cães sejam um dos animais de convívio mais estreito e harmonioso com o ser humano, quando esta referida população se encontra fora do controle, ela pode gerar agravos, tanto com relação à saúde humana e de outros animais quanto ao meio ambiente. Assim, estudos relacionados à estimativa de seu tamanho populacional e aos métodos de controle são importantes para o desenvolvimento de estratégias cada vez mais eficazes. Este estudo teve como objetivos principais avaliar a técnica de fotoidentificação para a espécie canina e apresentar uma proposta para aprimorar o método de captura-recaptura fotográfica. Para tanto, foram obtidas fotografias de cães a partir de duas fontes distintas, sendo uma a partir de cães internados no canil de adoção do Centro de Controle de Zoonoses (CCZ) - grupo controle, padrão ouro - e a outra de cães soltos nas ruas de Ibiúna/SP. Os cães do CCZ foram fotografados seguindo 4 tipos diferentes de protocolo, o que gerou 4 diferentes padrões de catálogos fotográficos. Esses 4 catálogos se diferenciaram entre si em termos de visualização do cão e de número de fotografias necessárias para apresentar cada animal (dependendo do catálogo, este poderia ser representado por uma a quatro fotografias). Em um segundo momento, foi realizado uma busca de cães livres nas ruas do bairro de Santa Lúcia (lbiúna/SP) por três dias. Cada animal encontrado foi fotografado e estas foram classificadas conforme o padrão dos catálogos determinados para as fotografias dos cães do CCZ. Por fim, 103 voluntários observaram pares de conjunto de fotografias dos cães (tanto as do CCZ quanto as do bairro) por meio da Internet e apontaram quais deles correspondiam aos mesmos cães, na opinião deles. Além disso, seguindo o método clássico de captura-recaptura, foi estimado a população de cães nas ruas do bairro sob a ótica do pesquisador (isto é, de uma única pessoa). Entre os principais resultados, tomando as fotos obtidas do CCZ como padrão ouro, as probabilidades de se identificar e de se distinguir corretamente os cães por meio da fotografia (para o voluntário) foi de $95,0 \%$ e 99,8\%, respectivamente, e o índice Kappa calculado para a concordância entre os resultados dos voluntários e do padrão ouro foi de 0,963 . Com base no uso das probabilidades calculadas do padrão ouro, a estimativa da população canina livre passou por um ajuste e foi estimada em torno de 65 animais (I.C. 95\% 64 a 67 animais). A estimativa das probabilidades de identificação foi interessante no sentido de ajustar o $\mathrm{N}$ calculado, tornando esta estimativa mais precisa.

Descritores: Fotografia; Técnicas de estimativa; Estimativas de população; Cães. 


\section{Summary}

Shimozako HJ. Optimization of photographic capture-recapture technique for estimation of free canine population in public roads [dissertation]. Faculty of Medicine, University of Sao Paulo, SP (Brazil); 2008.

The dog is one of the most popular pet in the world. However, if this population is out of control, injuries against human beings, other animals and environment can occur. Therefore, studies related to dog population are important in order to optimize methods and strategies of control. The main objectives of this research are evaluating the photo-identification technique for dogs and presenting a suggestion to improve the photographic capturerecapture method. For this, pictures of dogs were acquired from two different sources. One of them was the Zoonosis Control Center (ZCC) - gold standard - and the other one were the free dogs from Ibiúna City streets. The dogs from ZCC were photographed following four protocols. Therefore, I obtained four photographic catalogs. The difference between these catalogs was the visualization of dog's physical characterestics and the necessary number of pictures (one to four) to present each animal. Second, a survey of free dogs in the Ibiúna City had been carried out during three days. Each dog found in the streets was photographed and, after that, the pictures were classified according to the model of catalogs acquired from ZCC dog's pictures. Finally, 103 volunteers observed set of pairs of pictures (both ZCC and streets) by means of Internet and pointed which of them were from the same dogs. In addition, the dog population was estimated by following the classical capture-recapture method. Considering the results from the ZCC pictures observation, the correctly identifying and distinguishing dogs probabilities by means of pictures (for the volunteer) was $95,0 \%$ and $99,8 \%$, respectively. In this case, the kappa value between these volunteers' results and the gold standard was 0,963 . Using the calculated probabilities from the gold standard, the estimated population $(\mathrm{N})$ was adjusted to about 65 animals (C.I. 95\% 64 to 67 animals). The estimation of the probabilities from the gold standard was interesting for adjusting the calculated $(\mathrm{N})$ and improving the precision.

Descriptors: Photography; Estimation Techniques; Population estimates; Dog. 


\section{INTRODUÇÃO}

O controle de população de cães é uma atividade de grande importância dentro da saúde pública (humana e veterinária).

São vários os agravos que essa população, quando fora do controle, pode gerar: difusão de zoonoses, agressões físicas, acidentes de trânsito e desequilíbrio ecológico ao predar diferentes espécies silvestres (predatismo) são os principais tipos.

Estudos relacionados à estimativa de seu tamanho populacional e aos métodos de controle são importantes para o desenvolvimento de estratégias cada vez mais eficazes. Entretanto, tais pesquisas não costumam ser simples, pois se trata de uma espécie animal marcada pelo convívio com seres humanos. Isto explica, em parte que a dinâmica populacional canina não depende apenas dela, mas recebe influência externa (representada pela interferência humana, tais como oferecimento de água, abrigo, alimento e acesso às vias públicas).

O presente trabalho apresentará uma sugestão para otimização e a avaliação da técnica de captura-recaptura fotográfica como ferramenta para a estimativa de tamanho populacional canino livre em vias públicas. Esperase que esta técnica seja útil para as estratégias de controle populacional canino no futuro. 


\section{OBJETIVOS}

\subsection{Objetivos gerais}

Avaliar a técnica de foto-identificação para a espécie canina e apresentar uma proposta para aprimorar o método de captura-recaptura fotográfica, assim como discutir sobre sua eficácia e limitação.

\subsection{Objetivos específicos}

1. Estimar a probabilidade de identificação dos cães por meio de fotografias;

2. Estimar a população canina livre nas vias públicas do bairro de santa Lúcia no município de Ibiúna/SP;

3. Estimar o grau de concordância entre os observadores em relação ao padrão ouro $(C C Z)$. 


\section{REVISÃo DE LITERATURA}

\subsection{Seres humanos e cães: o processo de domesticação}

O convívio entre seres humanos e cães (Canis lupus familiaris) provém de longa data, sendo que pesquisas sobre DNA sugerem que o processo de domesticação ${ }^{1}$ desta espécie se iniciou a 100.000 anos, muito antes da origem da agropecuária (Davis; Valla, 1978). O início desse processo ocorreu a partir do contato entre os homens e os lobos (que estão entre os primeiros animais domesticados) (WHO; WSPA, 1990; Reichmann et al., 2000b; Beck, 2002). Nessa época, em decorrência da transformação sofrida pelo ecossistema natural em favor da instalação do ambiente antrópico $^{2}$, houve a eliminação de diversas espécies, reduzindo-se a diversidade. Em contrapartida, houve a criação de novos nichos, devido à própria ação humana, dando oportunidade para a sobrevivência e a adaptação a algumas delas neste novo meio (Forratini, 1992; Gomes et al., 2004; Gioberchio, 2005).

Assim, os cães tiveram rapidamente seus valores reconhecidos, conforme as circunstâncias culturais e econômicas dos povos, e eles passaram a ser utilizados para benefício humano (tornando-se, por exemplo,

\footnotetext{
${ }^{1}$ Domesticação pode ser conceituada como o processo pelo qual o homem adaptou plantas e animais que ele procurou propiciar-se para utilizá-las do ponto de vista econômico e hedonístico. Esse processo se baseou na modificação do patrimônio genético desses seres por meio da seleção artificialmente induzida. Tais modificações gênicas tornaram esses seres domesticados mais aptos a viverem sob condições antrópicas do que sob condições naturais. Como resultado, a evolução desse processo criou uma biota capacitada a viver exclusivamente no ambiente humano (Forratini, 1992).

2 Por ambiente antrópico entende-se como aquele gerado a partir da ação do ser humano (Forratini, 1992).
} 
animais de guarda e caçadores). A partir de então, os homens se tornaram componentes ecológicos na evolução e sobrevivência desses animais (Feldmann, 1974; Beck, 1975; Larrieu et al., 1992; Wanderler et al., 1993; Reichmann et al., 2000b; Thrusfield, 2004; Gioberchio, 2005). Em 1993, Wandeler et al. descrevem que a população canina estava estimada em torno de 500 milhões de indivíduos no mundo, sendo que em algumas localidades havia mais cães do que seres humanos.

A domesticação desenvolve-se até os dias atuais, em um processo de mútua adaptação, em que tanto o domesticado quanto o domesticador interagem mutuamente. Tais interações não apenas modificam os seres domesticados, mas promovem alterações ecológicas e sociais nas populações humanas (Forratini, 1992). A companhia e a convivência com animais de estimação trazem benefícios de nível fisiológico, social e psicológico para as pessoas (Feldmann, 1974; WHO; WSPA, 1990; Bahr; Morais, 2001; Gioberchio, 2005). Os principais efeitos benéficos estão resumidos no Quadro 1. 
Quadro 1: Efeitos benéficos dos animais de estimação (Bahr; Morais, 2001).

\begin{tabular}{|c|c|c|}
\hline Efeitos psicológicos & Efeitos fisiológicos & Efeitos sociais \\
\hline $\begin{array}{l}\text { Melhora no aprendizado de } \\
\text { crianças }\end{array}$ & $\begin{array}{l}\text { Diminuição da ativação } \\
\text { neuroendócrina do estresse }\end{array}$ & $\begin{array}{l}\text { Auxílio na socialização de } \\
\text { criminosos, idosos e } \\
\text { deficientes físicos e } \\
\text { mentais }\end{array}$ \\
\hline $\begin{array}{l}\text { Auxílio no desenvolvimento } \\
\text { emocional de crianças }\end{array}$ & Diminuição da pressão arterial & $\begin{array}{l}\text { Auxílio no desenvolvimento } \\
\text { social de crianças }\end{array}$ \\
\hline Diminuição da ansiedade & $\begin{array}{l}\text { Diminuição da freqüência } \\
\text { cardíaca }\end{array}$ & $\begin{array}{l}\text { Auxílio em programas de } \\
\text { reabilitação }\end{array}$ \\
\hline Diminuição do estresse & $\begin{array}{l}\text { Aumento da expectativa de } \\
\text { vida }\end{array}$ & $\begin{array}{l}\text { Aumento da interação } \\
\text { interpessoal }\end{array}$ \\
\hline Diminuição da depressão & $\begin{array}{l}\text { Estímulo a atividades } \\
\text { saudáveis }\end{array}$ & \\
\hline Melhora qualidade de vida & & \\
\hline Diminuição da solidão & & \\
\hline Melhora do humor & & \\
\hline
\end{tabular}

Como resultado do processo de domesticação, os cães podem ser caracterizados por notável variação em relação ao porte, à longevidade, à idade da maturidade, aos aspectos comportamentais e aos padrões de reprodução entre as raças (Hafez, 1982).

\subsection{Seres humanos como proprietários dos cães}

Simultaneamente ao processo de domesticação, ano após ano, a história nos mostra que a tendência é de o meio urbano crescer cada vez mais. Conseqüentemente, a população humana tende a se aglomerar gradativamente, não se enquadrando em limites ecológicos, tornando o 
ecossistema artificial. Além disso, a aceleração extremamente exagerada deste processo gera problemas no desenvolvimento dela (Forratini, 1992).

Com a expansão das cidades, o desenvolvimento dos processos de urbanização (considerada um dos principais meios de pressão sobre o meio ambiente) levou às modificações na estrutura dinâmica da população canina (Beck, 1975; Larrieu et al., 1990). Segundo Thursfield (2004), o número de donos de animais domésticos têm aumentado. Os cães (além de outras espécies), por conviverem no mesmo ambiente que os humanos e pela posição de animais domesticados, sofrem alterações e adaptações em função do ambiente antrópico e da realidade social na qual vivem (Reichmann et al., 2000b; Campos, 2004). O uso deles por questão de caça, de segurança, de gosto e companhia, de práticas esportivas e de trabalho são alguns exemplos de utilização desses animais atualmente (WHO; WSPA, 1990).

Entretanto, assim como qualquer outro animal doméstico, os cães necessitam de cuidados mínimos que visam tanto preservar a saúde deles quanto de outros seres vivos que convivem com eles (Reichamann et al., 2000b). Além disso, a criação desses animais implica que os seus respectivos proprietários sejam responsáveis por eles (posse responsável ${ }^{3}$ ) (WHO; WSPA, 1990). Contudo, esse pressuposto não é seguido à regra em várias localidades (Gomes et al., 2004). O fato de serem sujos, de morderem e de causarem doenças são alguns exemplos de situações que podem levar à rejeição do animal (WHO; WSPA, 1990). Magnabosco (2006) comenta que

\footnotetext{
${ }^{3}$ Por "posse responsável" entende-se: exercício consciente e edificante da cidadania, a educação e os hábitos culturais diferenciados de uma sociedade (Reichmann et al., 2000b).
} 
a mudança de domicílio e constantes reclamações de vizinhos são situações que motivam o descarte de animais sadios. Reichmann et al. (2000b) referem que hábitos inadequados, procriação descontrolada, deterioração da qualidade de vida em certas comunidades humanas também levam ao excesso populacional de animais domésticos. A título de exemplo, Lima Júnior (1999) cita em seu trabalho que no município de Recife/PE há elevadas densidades caninas, com baixos níveis de restrição, o que se explica pelo elevado adensamento populacional em áreas limitadas, com muitas famílias de baixa renda, habitando residências cujo tipo favorece a não restrição dos cães.

No caso de filhotes, quando estes vão adquirindo autonomia das mães, passam a causar alguns contratempos que se intensificam à medida que crescem. Assim, muitos são abandonados ou eliminados de forma cruel (Reichmann et al., 2000b).

Campos (2004) relata que vários cães e gatos errantes são encontrados no campus Luiz de Queiroz, em Piraciaba/SP, provavelmente originados de casos de abandono. Feldmann (1974) descreve que o mais sério problema canino urbano está relacionado aos cães cujos donos não os desejam mais e os cães irrestritos ou parcialmente restritos que têm livre acesso às ruas.

Para Wanderler et al. (1993), os cães são individualmente diferentes, sendo que sofrem diferenças no status de posse, nos graus de restrição de movimento, nas interações sociais e reprodutivas e na dependência ao cuidado humano. Além disso, são animais altamente prolíferos (WHO; 
WSPA, 1990). Há relato de estudos de população canina em que os cães têm acesso às ruas para que possam ter suas necessidades (seja fisiológica ou alimentar) complementadas ou realizadas, ou para aliviar a falta de espaço das residências (Nunes et al., 1997; Lima Júnior, 1999; Soto, 2003; Sallum, 2005) ou mesmo por negligência dos proprietários.

Childs et al. (1998) descrevem que nas Filipinas, em um estudo sobre estimação de densidade populacional canina, todos os cães com proprietários amostrados tinham livre acesso às ruas, tanto durante o dia quanto a noite. Beran e Frith (1988) relatam em seu trabalho realizado em Guayaquil (Equador) que há proprietários que permitem que os cães se movimentem livremente ou parcialmente pelas ruas da cidade (manhã e noite ou somente durante o dia), dependendo da classe social ao qual pertenciam. Feldmann (1974) relata que o tamanho da população livre nas ruas depende parcialmente da dimensão da população domiciliada e das atitudes que os proprietários tomam em relação ao confinamento e à procriação dos seus animais.

Considerando que um cão encontrado em uma via pública pode tanto ter proprietário ou não, a seguinte classificação foi elaborada para caracterizar os cães com relação ao seu nível de restrição e a relação de responsabilidade de posse de seus proprietários (WHO; WSPA, 1990):

a) Cão supervisionado ou controlado: são cães totalmente restritos, que possuem proprietários e obtêm alimento, abrigo e cuidados gerais dele. São conhecidos como animais domiciliados; 
b) Cão de família: são cães com proprietários, mas parcialmente restritos, e obtêm abrigo e alimento deles (embora os cuidados gerais sejam menos rigorosos, saindo às ruas sem acompanhamento e restrições). Conhecidos como semidomiciliados;

c) Cão comunitário ou de vigilância: são cães sem proprietários definidos, parcialmente restritos ou irrestritos. Permanecem próximos a residências ou a estabelecimentos comerciais, sem a identificação de um único proprietário;

d) Cão selvagem: são cães sem proprietários.

Em termos ecológicos e epidemiológicos, os cães de família e o comunitário são os de maior risco, tanto por terem acesso às vias públicas (expondo-se ao risco de entrar em contato com agentes etiológicos - seja por meio do contato com outros animais ou com o próprio meio ambiente - e assim disseminá-los) quanto pela manutenção da sobrevivência oferecida pelos seus proprietários, seja ela parcial ou total (Feldmann, 1974; WHO; WSPA, 1990; Reichmann et al., 2000b; Sallum, 2005).

Como exemplo, Lima Júnior (1999) estima que cerca de $40 \%$ dos cães são considerados parcialmente restritos ou irrestritos em Recife/PE e eles se concentram mais nas áreas pobres da cidade, onde as ruas são mais estreitas e os domicílios mais próximos, criando um ambiente familiarizado e estendendo o ambiente extradomiciliar ao da residência original. Campos (2004) apresenta em seu trabalho que cães são mais abundantes em ambiente suburbano que rural. 


\subsection{Os problemas causados pela população canina livre nas vias públicas}

Neste trabalho, será estudada a população canina livre nas vias públicas ${ }^{4}$, ou seja, os cães de família, de vigilância e os selvagens. Entre os principais agravos ligados a esta população de animais estão a difusão de zoonoses, os acidentes de trânsito, as agressões físicas por mordedura, o desequilíbrio ecológico e a poluição ambiental (Feldmann, 1974; WHO; WSPA, 1990).

Thrusfield (2004) observa que a população canina pode ser considerada como contígua ${ }^{5}$, uma vez que os cães se movem livremente dentro das cidades e contactam com indivíduos de outras populações animais (gatos, roedores, artrópodes, bovinos, ovelhas, outros animais da fauna silvestre), incluindo o próprio ser humano (Acha; Szyfres, 1999; Savani et al., 1999; Savani et al., 2003; Campos, 2004; Maciel et al., 2004; Thrusfield, 2004; Macpherson, 2005; Vasconcellos et al., 2006) e, devido a tal fato, estão entre os principais agentes difusores e reservatórios de zoonoses (Larrieu et al, 1990; WHO; WSPA, 1990; Larrieu et al, 1992; Palatnik-de-Sousa et al., 2001; Slater, 2001; Maciel et al., 2004). Este fato, somado à expansão dos processos de urbanização, contribui para a

\footnotetext{
${ }^{4}$ Segundo a WHO e a WSPA (1990), o nível de supervisão e de negligência dos proprietários sobre os cães é bastante variável de uma localidade a outra. Portanto, não será atribuído neste trabalho nenhuma outra nomenclatura mais específica a respeito dos cães livres nas ruas, uma vez que esses animais podem tanto ser considerados como perdidos, abandonados ou meramente andarilhos.

${ }^{5}$ A população contígua é uma na qual há muito contato entre os animais de uma população e membros de outras populações (Thursfield, 2004).
} 
elevação das interações entre cães, homens e as outras espécies de animais (Nieto et al., 2004).

Portanto, o alto contingente populacional canino mantido sem controle, sem cuidados de prevenção de doenças e em más condições de vida eleva o risco de transmissão de zoonoses (Feldmann, 1974; Reichmann et al., 2000b; Gomes et al., 2004). O controle dessa classe de doenças é a preocupação mais importante para autoridades de saúde pública na área veterinária (Nieto et al., 2004; Thursfield, 2004).

Do ponto de vista sanitário, o aumento dessas interações trouxe conseqüências negativas, já que certas zoonoses e injúrias relacionadas ao contato com animais (que originalmente tinham caráter ocupacional) começaram a ser relacionadas a toda população humana (Beck, 1975). Segundo Thrusfield (2004), mais de $80 \%$ dos agentes infecciosos para os quais o homem é suscetível são compartilhados por outras espécies animais. É a partir desse relacionamento do ser humano com outras espécies (no caso, o cão doméstico) em que se baseia grande interesse da epidemiologia na compreensão da dinâmica de transmissão de doenças infecciosas. Logo, a dinâmica das comunidades assim estabelecidas no meio antrópico reflete os aspectos epidemiológicos próprios das doenças que delas resultam (Forratini, 1992). Logo, Nieto et al. (2004) descrevem em seu trabalho que os novos hábitos e estilos de vida de uma sociedade eminentemente urbana implicam na necessidade de avaliar e valorizar o papel que os animais de companhia representam em sua casuística assim como os padrões epidemiológicos das enfermidades transmitidas por eles. 
Segundo a WHO e a WSPA (1990), o cão está relacionado à transmissão de mais de 100 zoonoses, entre elas a raiva, o complexo equinococose-hidatidose, febre maculosa, doença de Chagas, leishmaniose visceral, diphyllobothriasis, trichnosis, dirofilariose, strongyloidiasis e larva migrans (Toxocara canis e Ancilostoma brasiliensis).

Nos Estados Unidos, Beck (1975) destaca que a alta mortalidade dos cães, devido aos métodos de eliminação e aos acidentes de trânsito, somado ao alto crescimento populacional tem tornado a população mais jovem, sendo a pirâmide etária a característica de um triângulo com a base larga. A população se tornando mais jovem, uma proporção de animais não imunes tende a crescer dentro dela. Animais jovens são mais tendenciosos a morder e são mais susceptíveis às doenças e infestações por vermes. Os vermes são um grande problema veterinário e o Ascaris lumbricoides e o Toxocara canis estão entre os principais agentes.

Além do fato de serem potenciais transmissores de zoonoses, os cães são também agentes causadores de acidentes, sendo que as mordeduras estão entre os principais agravos (embora seja um problema pouco reconhecido como de saúde pública), principalmente entre os países em desenvolvimento (Feldmann, 1974; Wandeler et al., 1993; Larrieu et al., 1992; Yue-Fang et al., 1997; Patrick; O’Rourke, 1998; Reichmann et al., 2000b; Slater, 2001). Vale ressaltar a importância dos custos com o tratamento para este tipo de agravo e das seqüelas psicológicas que igualmente afetam o acidentado, sendo que Yue-Fang et al. (1997) destacam que em 1992 os Estados Unidos chegou a gastar cerca de 82,9 
milhões de dólares por ano com o tratamento desse tipo de agravo. A WHO e WSPA (1990) citam que o Reino Unido chegou a gastar anualmente cerca de 70 milhões de libras por ano com o tratamento de diversos tipos de agravos envolvendo cães, incluindo acidentes por mordedura.

Nos trabalhos sobre acidentes por mordedura descritos por Beck (1975), Patrick e O’Rourke (1998) e Ciampo et al. (2000), em muitos casos os cães agressores eram conhecidos dos acidentados. Entretanto, supondo que esses animais tenham acesso às vias públicas, há a possibilidade de entrar em contato com outros cães (Paranhos, 2002; Soto, 2003; Thrusfield, 2004, Sallum; 2005). No trabalho desenvolvido por Paranhos (2002), 11,58\% dos cães não foram vacinados contra a raiva. Magnabosco (2006), registrou em seu estudo um percentual de $9,87 \%$ de cães não vacinados nos últimos 12 meses a partir da data do estudo. Patrick e O'Rourke (1998) citam em seu estudo que na maioria dos acidentes os cães não eram vacinados, o que potencializa o risco de transmissão da raiva.

Lima Júnior (1999) relata em seu trabalho em Recife/PE que a maior parte dos cães raivosos registrados tinham acesso ao ambiente extradomiciliar e que apenas $14,5 \%$ dos cães capturados foram considerados imunologicamente protegidos contra a raiva (ou seja, título de anticorpos $\geq 0,5 \mathrm{UI} / \mathrm{ml}$ de soro). Sallum et al. (2000), em seu estudo sobre a soroprevalência de raiva nos cães de rua do município de São Paulo, descrevem a prevalência de $16,5 \%$ de cães protegidos contra a raiva dentro dessa população. 
É importante ressaltar que, no controle de zoonoses e da população canina, aspectos culturais da população humana podem influenciar no resultado dessas atividades (Beck, 1975; Larrieu et al., 1990; WHO; WSPA, 1990; Larrieu et al., 1992, Childs et al. 1998; Lima Júnior, 1999; Kitala et al., 2001; Slater, 2001; Matos et al., 2002; Soto, 2003; Flores-Ibarra; EstrellaValenzuela, 2004; Macpherson, 2005; Sallum, 2005). Assim, por exemplo, em 1993, Wanderler et al. relatam que no Siri Lanka havia influência de aspectos culturais que impediam que o tratamento pós-exposição fosse executado. Nesse país, além da falta de conhecimento sobre a doença, crenças religiosas e sobrenaturais eram responsáveis pelo pouco sucesso alcançado no controle da raiva, além das próprias falhas médicas.

Assim, fica caracterizada a necessidade de programas educativos envolvendo toda a população objetivando a vivência harmoniosa entre cães e seres humanos e a profilaxia contra esses agravos (Yue-Fang et al., 1997; Patrick; O’Rourke, 1998; Ciampo et al., 2000; Magnabosco, 2006).

Do ponto de vista ambiental, a coexistência entre cães e seres humanos têm causado contaminação fecal do meio ambiente, o que sugere, por conseqüência, que sejam aplicadas atividades de controle de população canina para tal finalidade (Feldmann, 1974; Beck, 1975; Larrieu et al., 1992; Nunes et al., 2000; Reichmann et al., 2000b; Gomes et al., 2004). Já para Côrtes et al. (1988), é necessário que haja medidas de controle de poluição em lugares públicos (praias, "campings", tanques de areia, praças) por fezes de cães e de gatos, principalmente em países desenvolvidos. Devem ser considerados também que os cães podem ser causadores de barulhos, 
odores e outros incômodos. Além disso, direta ou indiretamente, as carcaças dos cães originadas da eutanásia também contribuem para a poluição ambiental, caso não haja um método de controle eficaz sobre a destinação deste material (WHO; WSPA, 1990).

Beck (1975) comenta em seu estudo que nos Estados Unidos fora observado um aumento no número de cães de grande porte, enquanto que os de pequeno porte tinham se mantido constante. Esse fato condizia com a motivação das pessoas em se proteger da criminalidade, tendo assim um meio de se conseguir segurança e proteção. Todavia, o aumento da biomassa populacional levou ao aumento da produção fecal, sendo em média 340g/dia/cão de grande porte. Assim, nessa época, no caso de Nova York, isso significou que as ruas e o sistema de esgoto recebera cerca de 187 toneladas de fezes diariamente, segundo a estimativa de meio milhão de cães de grande porte na cidade.

Pelo fato de os cães serem a espécie animal mais difundida pelo mundo, a competição com animais silvestres onívoros tem crescido. Além disso, não só houve aumento deste tipo de relação ecológica, mas também têm sido relatados casos de predação de certas espécies silvestres pelos cães (WHO; WSPA, 1990, Reichmann et al., 2000b, Campos, 2004).

Campos (2004), ao analisar amostras de fezes de cães em seu estudo no Campus de Piracicaba da Universidade de São Paulo, descreve que esses animais predaram algumas espécies silvestres e sinantrópicas, tais como Nasua nasua, Myocastor coypus, Galictis cuja, Didephis albiventris, Coendou prehensilis e Mus musculus (além de outros indivíduos 
não identificados das famílias Muridae e Leoporidae). Ainda, apresentou como consumo de mamíferos por cão estimado entre 16,76 e 25,42 kg/indivíduo/ano, ou seja, a estimativa da pressão de predação da fauna silvestre nessa região. Segundo o autor, embora alguns acreditem que os cães causem impacto negativo sobre a fauna silvestre, há aqueles que acreditem que esse fato pode ser amenizado se outras fontes de alimentos estiverem disponíveis (normalmente os oferecidos pelos humanos).

\subsection{A dinâmica da população de cães nas vias públicas}

Vários aspectos interferem na dinâmica e na estrutura da população canina, tais como o sexo, a idade, a natalidade, a sobrevivência e a mortalidade. Quando esta população se encontra em uma situação ótima, ela inicialmente cresce exponencialmente, o que significa que a taxa de natalidade supera a taxa de mortalidade. Entretanto, logo em seguida ao crescimento exponencial, as taxas de natalidade e de mortalidade tendem a decrescer e a crescer, respectivamente, até que ambas as taxas se tornem iguais e a população permaneça em equilíbrio. Este patamar máximo onde se estabeleceu o equilíbrio é conhecido por capacidade de suporte do meio e ele é influenciado pela disponibilidade, qualidade e distribuição de fatores de sobrevivência da espécie em estudo, tais como água, abrigo e alimento. A densidade populacional dos vertebrados é geralmente próxima da capacidade de suporte do meio. Logo, qualquer redução da densidade populacional é rapidamente compensada pela reprodução da espécie e 
aumento da sobrevivência. No caso dos cães, quando indivíduos da população são removidos, a expectativa de vida dos remanescentes aumenta, pois estes conseguem melhor acesso aos recursos e há menor competição por eles (WHO; WSPA 1990; Reichmann et al., 2000b).

A revisão de literatura elaborada por Wanderler et al. (1993) cita o caso da campanha de controle da raiva em Colombo (entre 1970 e 1980), em que a estratégia foi de remover a população de cães sem supervisão e vacinar os animais domiciliados. Contudo, esta meta não foi alcançada, pois a quantidade dos animais removidos foi compensada pela reprodução deles. Lima Júnior (1999) e Gomes et al. (2004) estimam para Recife/PE e uma área do Distrito Administrativo da Brasilândia (São Paulo/SP), respectivamente, altas taxas de natalidade e de mortalidade (principalmente entre filhotes e jovens), o que explica o alto e rápido ciclo de recrutamento e a expectativa de vida reduzida, o que implica na manutenção de um seguimento populacional suscetível à doenças infecciosas.

A sobrevivência dos cães está condicionada às características do meio em que vivem e é um fator importante para o estudo da ecologia dessa espécie. Entre as principais características de um ecossistema humano pode se destacar (Forratini, 1992):

1) As funções são controladas basicamente por fatores sociais, econômicos e políticos, em detrimento dos fatores naturais;

2) Dependência contínua e constante da entrada de recursos para a geração de energia (em ecossistemas naturais, isso ocorre 
por agentes como o vento, as chuvas, as migrações de animais

e são em menor escala se comparado com o humano);

3) As mudanças no equilíbrio deste ecossistema dependem fundamentalmente de fatores sociais.

Por conseqüência, considera-se que o meio ambiente interfere nas condições de sobrevivência de cães livres em vias públicas por ofertar abrigo, água e alimentos por meio de mecanismos não só naturais, mas também artificiais. Os abrigos de áreas urbanas podem estar disponíveis na forma de construções abandonadas, terrenos baldios, depósitos de lixo, espaços abertos em áreas cultivadas, ruas, becos, pátios de estacionamento, áreas abandonadas, como quintais, garagens e outros. A água, em fontes naturais ou artificiais. O alimento, em recipientes de lixos domiciliares, hospitalares ou de restaurantes e bares, em más condições de acondicionamento, depósitos de lixo domiciliar, aterros a céu aberto, lixo abandonado nas ruas ou em recipientes colocados nas entradas das residências para cães que por ali circulem (Daniels, 1987; Beran; Frith, 1988; WHO; WSPA, 1990; Wandeler et al., 1993; Lima Júnior, 1999; Reichmann et al., 2000b; Kitala et al., 2001; Campos, 2004; Gomes et al., 2004). Assim, para Wanderler et al. (1993), o fato de cães de família e de vizinhança serem freqüentemente cuidados por seres humanos faz com que a competição interespecífica por recursos acabe sendo eliminada e a intraespecífica, diminuída. Além disso, os cães podem ser considerados seres oportunistas, dada a variedade e a flexibilidade de itens alimentares que podem fazer parte do hábito alimentar destes animais (Campos, 2004). Magnabosco 
(2006) refere em seu trabalho que possuir animal de estimação estimula a cuidar de animais comunitários.

Campos (2004) relata que em seu trabalho que a maior abundância de cães foi notada nas áreas de maior fluxo de pessoas, indicando um estreito relacionamento que os humanos tem com eles. Nessas áreas, as pessoas geram grande quantidade de lixo, tornando uma grande fonte de alimento para cães e gatos errantes. Daniels (1987) relata que, em situações extremamente negativas aos cães (por exemplo, stress nutricional), podem chegar a ponto de cometer canibalismo. Shimozako et al. (2006), em seu trabalho relacionado ao mapeamento de casos de solicitação e de atendimento de apreensão de cães no município de São Paulo, descrevem que espacialmente houve uma relação entre os casos de apreensão, o tamanho da população canina domiciliada estimada local e os índices sociais e que, direta ou indiretamente, podem estar ligadas à capacidade de suporte desses locais, favorecendo a permanência dessa população de cães nas ruas.

A presença da população canina livre pode também estar condicionada à taxa reprodutiva desses animais e aos fatores de risco envolvidos com o acesso de cães domiciliados às vias públicas, e ambas estão sujeitas às influências do meio urbano. Esses animais geralmente pertencem a uma ou mais residências, mas são pouco supervisionados. Assim, eles reproduzem livremente e o sucesso na procriação tende a ser alto, pois há abrigo e proteção oferecidos pela comunidade local. Além disso, eles se alimentam de sobras presentes no lixo, o que pode 
potencializar a difusão de zoonoses. Tal situação é diferente da que ocorre com os cães supervisionados, em que a taxa reprodutiva é relativamente menor, há indivíduos castrados e os recursos para a sobrevivência dos cães são intencionalmente oferecidos pelo homem. Como conseqüência disso, a média de idade deste seguimento populacional se torna mais alta (WHO; WSPA, 1990). Gomes et al. (2004), em seu trabalho realizado em uma área do Distrito Administrativo da Brasilândia (São Paulo/SP), considerada de nível sócio-enonômico precária, apenas 6,69\% dos cães possuíam mais de 8 anos de vida.

Os descendentes desse seguimento de cães livres ou passam a pertencer aos cães de vizinhança irrestritos ou os errantes. Embora eles sejam tolerados pela comunidade, se alimentam irregularmente. Tendem a procurar por abrigo em construções inabitadas ou estruturas naturais. $\mathrm{O}$ sucesso da procriação destes cães é relativamente baixo, principalmente devido à falta de proteção adequada aos filhotes (WHO; WSPA, 1990; Wanderler et al., 1998 ${ }^{6}$, apud Magnabosco, 2006).

Em linhas gerais, a taxa reprodutiva está condicionada aos fatores de sobrevivência da espécie e estes fatores, por sua vez, são oferecidos pela própria comunidade e pela estrutura do ambiente urbano (Wanderler et al, 1993). Assim, isto parece estar relacionado ao nível sócio-econômicocultural de cada região, pois ela reflete a atitude das pessoas em relação aos cães (Lima Júnior, 1999). Larrieu et al. (1992) descrevem em seu trabalho, realizado em General Pico (Argentina), que o elevado número de

\footnotetext{
${ }^{6}$ Wanderler Al, Budde A, Kappeler A. Dog Ecology and dog rabies control. Reviews of Infectious Diseases. 1998; 10 (4): 684-8.
} 
cães estimado nessa região em relação à população humana local pode ser resultado de razões culturais.

Os cães são capazes de se movimentar com relativa flexibilidade pelas ruas (Shimozako et al., 2006). Esses animais, nas vias públicas, apresentam uma característica de marcação territorial conhecida por extensão domiciliar, que pode determinar os padrões de transmissão de doenças infecciosas. Assim, animais infectados tendem transmitir doença dentro de sua extensão domiciliar, mas não além dela (Thrusfield, 2004).

A estrutura social e o comportamento da população canina também são características que influenciam a ecologia desta espécie. Em média, os cães quando observados nas ruas encontram-se em $50 \%$ dos casos em grupos e $50 \%$ sozinhos. E, considerando a possibilidade de os cães viverem em grupos, o fato destes animais serem habituados a caçarem ou perseguirem presas, morderem pessoas, latirem e revirarem lixo em busca de alimento faz com que isto se torne mais um problema de saúde pública, conforme já salientado anteriormente. Além disso, o lixo que se encontra revirado, desorganizado e exposto a céu aberto pelos cães oferece meios para a proliferação de pragas e encarece o serviço de limpeza urbana (Beck, 1975).

\subsection{Importância de dados epidemiológicos}

Para efeito de planejamento e elaboração de estratégia de controle de zoonoses e de população animal (e seus conseqüentes agravos), a coleta 
de dados epidemiológicos é de suma importância. Pelo fato da população canina ser heterogênea, é necessário avaliá-los separadamente por seguimento (por exemplo, domiciliados e errantes, restritos e irrestritos). Além disso, o estudo da população de cães ajuda no planejamento e implementação das atividades de controle e para monitoramento da efetividade e da melhora do sistema (Magnabosco, 2006). O custo-benefício de um esquema de controle não pode ser avaliado sem as características da população canina, dos proprietários e do meio ambiente (WHO; WSPA, 1990; Reichmann et al.; 2000b).

O controle das doenças e da população animal depende da ecologia do cão, da biologia da população e do contexto sócio-cultural humano. 0 mais importante é o tamanho total da população de cães, que é indispensável para o planejamento de avaliação das medidas de manejo e para a avaliação do impacto causado por eles na saúde coletiva. As melhores ações a serem tomadas vão depender dos resultados das observações feitas e dos dados obtidos (WHO; WSPA, 1990; Reichmann et al., 2000b; Sallum, 2005).

A título de exemplo, a estimativa da população canina domiciliada oferece subsídios técnicos e argumentos para a otimização do planejamento das campanhas de vacinação contra a raiva, cuja estratégia e planejamento se baseiam na razão cão/homem estimada para determinada região (WHO; WSPA, 1990; Nunes et al., 1997; Reichmann et al., 1999; Kitala et al., 2001; Dias et al., 2004). Porém, no caso da população de cães sem dono, segundo Sallum et al. (2000) não há, sob algum grau de precisão, o tamanho dessa 
população no que se refere ao município de São Paulo. Para Dias (2001), seria conveniente que estudos futuros permitissem a incorporação das populações não domiciliadas em suas respectivas localidades de referência.

Conforme concluído por Nunes et al. (1997) e Dias et al. (2004), o uso de uma razão única para a América Latina (como recomendado pela OMS) torna-se impraticável, devido à heterogeneidade das razões nas diversas localidades. A Tabela 1 apresenta algumas localidades e seus respectivos valores da razão cão/homem estimada. Ainda, informações escassas referentes à dinâmica das populações caninas se traduzem em linhas de ação empiricamente fundamentadas e sem mostrar, habitualmente, correlação entre os recursos econômicos e os êxitos obtidos em relação ao objetivo alcançado (Larrieu et al., 1990; Larrieu et al., 1992; Slater, 2001). 
Tabela 1: Razões cão:homem para diversas localidades.

\begin{tabular}{ccc}
\hline Local & Autor (ano) & Cão:Homem \\
\hline Estados Unidos & Beck (1975) & $1: 5,9$ \\
General Pico (Argentina) & Larrieu et al. (1990) & $1: 5,7$ \\
General Pico (Argentina) & Larrieu et al. (1992) & $1: 4,51$ \\
Lalitpur (Nepal) & Wanderler et al. (1993) & $1: 9.42$ \\
Araçatuba (SP) & Nunes et al. (1997) & $2,8: 10$ \\
Recife (PE) & Lima Júnior (1999) & $1: 9,1$ \\
Mirigama (Sri Lanka) & Matter et al. (2000) & $1: 5,74$ \\
Guarulhos (SP) & Dias (2001) & $1: 5,52$ \\
Machakos (Kenya) & Kitala et al. (2001) & $1: 7,7$ \\
São Paulo (SP) & Paranhos (2002) & $1: 7$ \\
Serra Azul (SP) & Mattos et al. (2002) & $1: 5$ \\
Ibiúna (SP) & Soto (2003) & $1: 3,77$ \\
Taboão da Serra (SP) & Dias et al. (2004) & $1: 5,14$ \\
Mexicali (México) & Flores-lbarra e Estrella-Valenzuela & $1: 4,3$ \\
(2004) & $1: 9$ \\
Jardim Paraná (São Paulo/SP) & Gomes et al. (2004) & $1: 11$ \\
Jardim Fortaleza (Guarulhos/SP) & Sallum (2005) & $1: 7,28$ \\
\hline São Paulo (SP) & Magnabosco (2006) &
\end{tabular}

Portanto, é importante que a coleta e a análise de dados epidemiológicos da população animal sejam periodicamente executadas para fins de vigilância e controle (WHO; WSPA, 1990; Nunes et al., 1997; Childs et al., 1998; Savani et al., 1999; Kitala et al., 2001; Paranhos, 2002; Savani et al., 2003; Flores-Ibarra; Estrella-Valenzuela, 2004). De maneira geral, um programa estratégico de controle populacional bem elaborado (considerando os dados epidemiológicos, a biologia dos cães e os aspectos 
culturais da população humana) pode ser capaz de trazer benefícios para a vida animal e humana (Beck, 1975; Wanderler et al., 1993; Slater, 2001).

\subsection{A saúde pública veterinária}

Meditsch (2006) descreve em sua revisão de literatura que, historicamente, a medicina veterinária tem estado presente na saúde pública desde a antiguidade, quando o ser humano começava a dar os primeiros passos sobre como conservar os produtos, caçar e domesticar animais. Neste caso, deu-se início as primeiras idéias de como amenizar a contaminação dos seus alimentos e o contágio de doenças. Desde então, várias evidências da evolução da medicina veterinária preventiva têm sido encontradas ao longo da história, como por exemplo:

- O Papiro Egípcio de 1900 a.C. (considerado o primeiro tratado de medicina veterinária);

- Os avanços dos estudos da bacteriologia em 1880 (especificamente, sobre a microbiologia e imunologia), que, juntamente com Pasteur, determinaram diversas descobertas epidemiológicas;

- Os avanços na indústria da carne durante o século XIX e da epidemiologia durante a Segunda Guerra Mundial;

- O início do reconhecimento da WHO na contratação de médicos veterinários consultores em 1944 e da criação da Secção de Saúde Veterinária em 1946. 
Assim, o médico veterinário passou ter maior participação em áreas técnico-administrativas e assim deu-se a sua inclusão normativa na saúde brasileira em 1991 (Meditsch, 2006).

O estudo e o controle da dinâmica das zoonoses fazem parte da área de atuação da saúde pública veterinária, que, segundo a WHO (2007), é definida como a soma de todas as contribuições para o bem-estar físico, mental e social dos seres humanos através da compreensão e aplicação da ciência veterinária. Segundo a Organização Pan-Americana de Saúde (Acha; Szyfres, 2001), zoonoses são definidas como infecções e/ou doenças naturalmente transmissíveis dos animais vertebrados aos homens ou que são comuns entre eles. Diversos tipos de agentes podem estar envolvidos: vírus, bactérias, fungos, parasitas e outros agentes não convencionais.

Dentro dessas contribuições que auxiliam as atividades relacionadas à saúde pública veterinária, há aquelas de competência da vigilância epidemiológica, cujo conceito legal é definido pela Lei Federal $n \cong 8080$ de

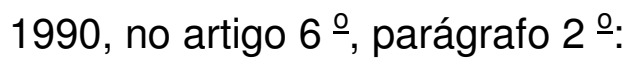

Entende-se por vigilância epidemiológica um conjunto de ações que proporcionam o conhecimento, a detecção ou prevenção de qualquer mudança nos fatores determinantes e condicionantes de saúde individual ou coletiva, com a finalidade de recomendar e adotar as medidas de prevenção e controle das doenças ou agravos. 
Em todo o mundo, as ações relacionadas à vigilância epidemiológica (no âmbito da saúde pública veterinária) são organizadas e executadas por instituições internacionais, federais, estaduais e municipais. $\mathrm{O}$ envolvimento de tantas repartições (além da crescente abordagem multidisciplinar dos estudos epidemiológicos (Slater, 2001)) reflete a importância dada às zoonoses e o grande desafio que representa o seu controle (Côrtes et al., 1988; Nieto et al., 2004). Dentro do contexto da população canina, tais ações objetivam auxiliar no controle do tamanho populacional e da difusão e da prevenção das enfermidades transmitidas (direta e indiretamente) por esta espécie e de outros possíveis tipos de agravos. Segundo Thrusfield (2004), a prevenção é uma parte cada vez mais importante no controle da doença, sendo melhor que a cura no campo humanitário e econômico.

Atualmente sabe-se que várias zoonoses (particularmente a raiva (Reichmann et al., 2000b; Slater, 2001)), são extremamente importantes devido ao risco de impacto na saúde pública. O Centro de Controle de Zoonoses (CCZ) é o órgão público responsável pelo controle desta classe de enfermidades (ou pelo menos exerce algum nível de influência sobre esse controle) e também é o responsável pelo controle populacional dos animais, de acordo com a legislação vigente no país (Reichmann et al., 2000a; Palatnik-de-Sousa et al., 2001; Gomes et al., 2004).

O médico veterinário tem uma função social importante dentro do contexto de saúde pública. Este profissional é uma das peças-chave nas atividades de controle de zoonoses e é influenciador direto sobre a promoção da saúde animal e do seu bem-estar. Suas funções se baseiam 
na proteção, prevenção e promoção à saúde humana e animal, além de atuar como agente multiplicador, orientando seus clientes nas clínicas veterinárias e notificando zoonoses aos órgãos públicos de vigilância e controle (Bahr; Morais, 2001; Thrusfield, 2004; Meditsch, 2006).

\subsection{O Bem-estar Animal}

Por bem-estar animal, entende-se como o estado de perfeita satisfação física ou moral (Dicionário Aurélio Eletrônico, 1999). Pela junção das definições de Ewbank (1986) ${ }^{7}$ e da WHO $(1983)^{8}$ (apud Thrusfield, 2004), pode-se definir bem-estar como "um estado de completo equilíbrio físico, mental e social, e não somente ausência de doença". Embora as questões pertinentes ao bem-estar animal estejam mais relacionadas aos animais de aspecto agropecuário, os seus princípios podem ser igualmente aplicados aos animais de companhia.

No contexto do presente trabalho, há exemplos de fatores que interferem negativamente sobre esse aspecto da população canina, tais como a posse irresponsável e a dinâmica do ambiente urbano (somado ao potencial demográfico das populações). Em ambas as situações, as possíveis conseqüências são (WHO; WSPA, 1990; Wanderler et al., 1993; Reichmann et al., 2000b; Paranhos, 2002; Grimaldi, 2004; Gomes et al., 2004):

\footnotetext{
${ }^{7}$ Ewbank R. Animal welfare - Is an epidemiological approach possible? In: Thrusfield MV. Society for Veterinary Epidemiology and Preventive Medicine. Edinburgh: 1986. p. 92-6.

${ }^{8}$ World Health Organization. Basic Documents. $35^{\text {th }}$ ed. Geneva: World Health Organization; 1983.
} 
- Risco de infecção por agentes patogênicos, zoonóticos ou não (infecciosos ou parasitários), e conseqüente difusão de agravos à saúde humana e a outras espécies animais;

- Casos de maus-tratos (em que pode ser caracterizado por casos de abandono e violência contra os animais);

- Diminuição da qualidade de vida dos cães.

Segundo a lei federal 9.605, de 12 de fevereiro de 1998, em seu artigo 32, é considerado crime contra a fauna a prática de abuso, maustratos, ferir ou mutilar animais silvestres, domésticos ou domesticados, nativos ou exóticos.

Sendo a situação de estresse oposta ao do bem-estar, Thrusfield (2004) refere que ela está envolvida como determinante secundário de várias doenças, o que pode contribuir ainda mais para a disseminação de zoonoses.

\subsection{O método de captura-recaptura}

A população alvo em estudo neste trabalho é a população de cães soltos nas vias públicas. No caso dos animais errantes (semi-domiciliados e os selvagens) eles são particularmente difíceis de obter informações, visto que se trata de um grupo pouco detectável, o que pode levantar censos com resultados distorcidos. Por conseqüência, tem-se então um dos maiores empecilhos para a se determinar o tamanho deste segmento populacional (Matter et al., 2000; Matos et al., 2002; Thrusfield, 2004). O estudo desta parcela populacional complementa aqueles relacionados ao 
dimensionamento de população domiciliada, já que mensura a quantidade de animais que podem causar problemas de saúde na comunidade ou que estão expostos ao risco de atropelamento ou de agressões (Sallum, 2005).

Um dos métodos para se estimar o tamanho desses indivíduos dessa classe é o da captura-recaptura (White et al. 1982; WHO; WSPA, 1990; Amstrup et al., 2005). No caso de estudos de população canina, há alguns estudos baseados no referido método (Wanderler et al., 1993; Childs et al., 1998; Matter et al., 2000; Sallum, 2005). O método de captura-recaptura para dimensionamento de populações caninas é um método recomendado pela WHO; WSPA (1990), sendo que, quando utilizada a técnica fotográfica de marcação, é denominado de Método de Beck.

Entretanto, tem sido no campo da ecologia onde o método de captura-recaptura passa por grande desenvolvimento (principalmente a partir das décadas de 30 e 40), tendo em vista o interesse em estimativas de populações de animais selvagens (White et al., 1982; Coeli et al., 2000; Amstrup et al., 2005).

Considerando a aplicação clássica da metodologia de capturarecaptura, o levantamento dos dados parte do princípio de que na amostra inicial, os animais encontrados na busca são capturados, marcados e liberados. Em seguida, uma nova amostra de indivíduos é capturada. Realizam-se, então, a contagem do número de animais marcados na amostra anterior e que apareceram na segunda amostra, dos que só apareceram na primeira amostra e dos que só apareceram na segunda. $O$ resultado deste processo pode ser representado por meio do Diagrama de 
Venn e da tabela de contingência apresentada na Figura 1 (Coeli et al., 2000).

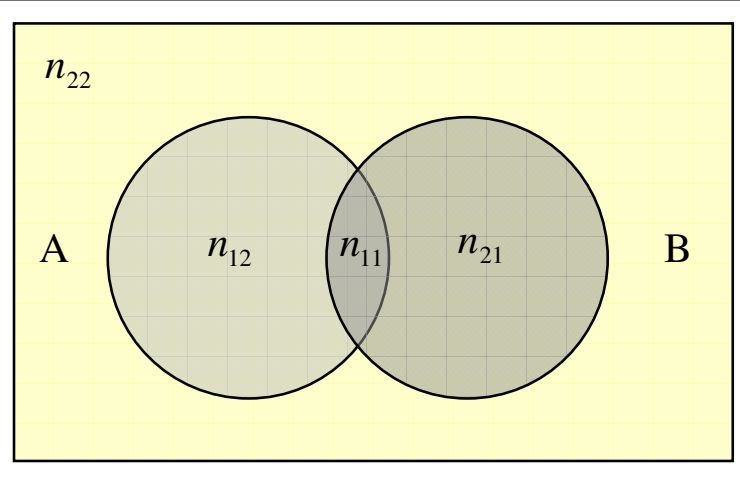

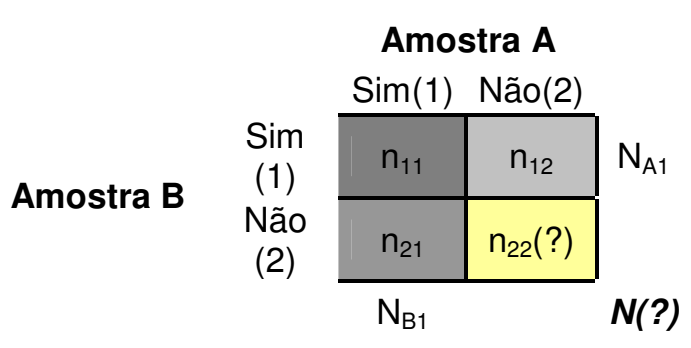

Onde,

$N=n_{11}+n_{12}+n_{21}+n_{22}=$ tamanho da população.

$N_{A 1}=n_{11}+n_{12}=$ total de indivíduos capturados na primeira amostra (amostra A).

$N_{B 1}=n_{11}+n_{21}=$ total de indivíduos capturados na segunda amostra (amostra B).

$n_{11}=$ número de indivíduos capturados na primeira e segunda amostra.

$n_{12}=$ número de indivíduos capturados somente na primeira amostra.

$n_{21}=$ número de indivíduos capturados somente na segunda amostra.

$n_{22}=$ número de indivíduos não capturados em nenhuma amostra.

Figura 1: Diagrama de Venn e tabela de contingência relativos a um processo de capturarecaptura envolvendo duas fontes (Fonte: Coeli et al., 2000). São realizadas duas amostragens em uma população de tamanho $N$. A primeira e a segunda amostras são representadas por $N_{A}$ e $N_{B}$, respectivamente. Os indivíduos de $N_{A}$ são marcados e são devolvidos ao restante da população. Em seguida, a partir de $N_{B}$ calcula-se o número de animais presentes em ambos os dias $\left(n_{l 1}\right)$ e aqueles que apareceram somente em $A$ ou em $B, n_{12}$ e $n_{21}$, respectivamente. O restante da população que não é amostrada está representada por $n_{22}$.

Para que as estimativas obtidas por meio do método de capturarecaptura sejam válidas, algumas premissas básicas devem ser assumidas 
(White et al., 1982; Seber, 1982 ${ }^{9}$, apud Barão-Acuña, 2002; Matos et al., 2002; Coeli, et al., 2000; Southwood, $1978^{10}$, apud Thrusfield, 2004; Amstrup et al., 2005):

a) Todos os elementos desta população devem ser homogêneos em relação aos atributos que determinam a probabilidade de seleção, ou seja, todos devem apresentar a mesma probabilidade de captura;

b) Os animais marcados na primeira amostra, ao serem liberados, se homogeinizam entre o restante da população;

c) Considerando que este tipo de estimativa é obtida em um curto período de tempo, a população em estudo é fechada, ou seja, não se observa nascimentos, mortes ou migrações durante o período de estudo;

d) Os animais agem independentemente;

e) Os animais não perdem as suas marcas.

Assim, a proporção de animais marcados-recapturados em uma segunda amostra se torna equivalente à proporção de animais marcados na população total (White et al., 1982; WHO; WSPA, 1990; Amstrup et al., 2005).

Modelos mais avançados assumem situações mais generalizadas a respeito das capturas (White et al., 1982; Amstrup et al., 2005), devido ao fato das hipóteses acima nem sempre corresponderem à realidade biológica.

\footnotetext{
${ }^{9}$ Saber GAF. The estimation of animal abundance and related parameters. $2^{\mathrm{a}}$ ed. London: Charles Griffin; 1982.

${ }_{10}$ Southwood TRE. Ecological Methods with Particular Reference to the Study of Insect Populations. 2a ed. London: Chapman and Hall; 1978.
} 
Partindo do esquema representado pela Figura 1, é possível estimar o total de indivíduos por meio de um índice simples, que parte do princípio da proporção entre indivíduos marcados e não marcados na primeira amostra:

$$
\frac{n_{11}}{N_{B 1}}=\frac{N_{A 1}}{N} \Rightarrow \hat{N}=\frac{N_{A 1} \cdot N_{B 1}}{n_{11}}
$$

sendo que o estimador $\hat{N}=\frac{N_{A 1} \cdot N_{B 1}}{n_{11}}$ é conhecido como estimador de Pettersen (White et al., 1982; Coeli et al., 2000; Barão-Acuña, 2002; Lincon, 1930 ${ }^{11}$, apud Thrusfield, 2004; Amstrup et al., 2005).

Uma abordagem diferente pode ser determinada para se evitar viés sobre o estimador de Pettersen, principalmente quando $n_{11}$ é muito pequeno, em especial se for zero. Para evitar essa situação, um animal extra é adicionado à freqüência de animais capturados em ambas ocasiões de tal forma que $n_{11}$ seja no mínimo igual à um. Conseqüentemente, $N_{A 1}, N_{B 1}$ e o tamanho total da população são acrescidos de uma unidade. Logo, este estimador, conhecido por estimador de Chapman, segue que (White et al. 1982; Amstrup et al., 2005):

$$
\hat{N}=\frac{\left(N_{A 1}+1\right)\left(N_{B 1}+1\right)}{\left(n_{11}+1\right)}-1
$$

Ambos os estimadores apresentam a mesma fórmula de variância, dada por (Amstrup et al., 2005):

$$
\operatorname{Var}(\hat{N})=\frac{\left(N_{A 1}+1\right)\left(N_{B 1}+1\right)\left(N_{A 1}-n_{11}\right)\left(N_{B 1}-n_{11}\right)}{\left(n_{11}+1\right)^{2}\left(n_{11}+2\right)}
$$

\footnotetext{
${ }^{11}$ Lincoln FC. Calculating waterfowl abundance on the basis of banding returns. USDA Circular. 1930; 118: 1-4.
} 
A WHO e WSPA (1990) apresentam um estimador alternativo cujo método é denominado Método de Beck:

$$
\hat{N}=\frac{\sum M n}{\sum m}
$$

onde:

- $\quad M=\mathrm{O}$ número de cães fotografados e considerados marcado (observado) em cada ocasião;

- $n=$ O número total de cães previamente observado, ou seja, total de cães distintos encontrados até a ocasião anterior;

- $m=$ Número de cães reconhecidos como sendo previamente fotografados (reobservados);

- $\hat{N}=$ Estimativa da população total.

A idéia de marcação neste método pode ser interessante do ponto de vista da vigilância epidemiológica, visto que ela pode fornecer informações sobre o movimento, a área domiciliar e territórios de animais selvagens e domésticos, o que pode ser muito relevante na transmissão de doenças (Thursfield, 2004).

O método de captura-recaptura tem sido aplicado em estudos diferentes daquele em que originalmente foi criado. Para exemplificar, há estudos sobre a sua aplicação na área médica (por exemplo, em estudos de recorrência de tumores, infecções e outras doenças) e na área industrial (visando análise de falhas e reparos de sistemas) (Yue Fang et al., 1997; 
Coeli et al., 2000; Amstrup et al., 2005; Cadwell et al., 2005; Luan et al., 2005).

Como formas de marcação, existem diferentes alternativas descritas na literatura. Amstrup et al. (2005) apresentam vários exemplos de marcação para as mais variadas espécies animais, como, por exemplo, uso de etiquetas em trutas, de brincos para ursos negros, de pulseiras nas patas de gansos canadenses e de rádio colares em ursos polares. Miller et al. (2005) apresentaram um trabalho onde é estudado o uso de material biológico para que o animal seja marcado geneticamente.

Uma técnica de marcação bastante referida é a foto-identificação, que tem sido observada em estudos desenvolvidos em diversos tipos de populações animais (Srbek-Araujo e Chiarello, 2005), entre as quais encontram-se os de espécies marinhas, como botos, baleias e leões marinhos (McConkey, 1999; Barão-Acuña, 2002; Zeh et al., 2002), de chimpanzés no Gombe (Goodall, 1986), de primatas de diversas espécies no monte Kowloon em Hong Kong (Wong; Ni, 2000), de lobos (Trolle et al., 2007) e de certas espécies de felinos silvestres (Karanth, 1995; Carbone et al., 2001; Silver et al., 2004; Maffei et al., 2005). A idéia do uso da fotografia é de não correr o risco de se esquecer das características do animal observado (WHO; WSPA, 1990).

No caso do cão, há relatos sobre o uso de coleiras (WHO; WSPA, 1990; Wanderler et al., 1993; Childs et al., 1998; Matter et al., 2000; Reichmann et al., 2000b; Matos et al., 2002), de brincos (Trusfield, 2004), de tatuagens (WHO; WSPA, 1990; Childs et al., 1998; Thrusfield, 2004), de 
microchips (WHO; WSPA, 1990) e de técnicas fotográficas, no qual a marcação se baseia no registro do fenótipo do indivíduo (Beran; Frith, 1988; WHO; WSPA, 1990; Pal et al., 1998b; Reichmann et al., 2000b; Beck, 2002; Sallum, 2005). Daniels e Bekoff (1989) relatam em seu estudo a caracterização dos cães por meio de registro de seu fenótipo, comportamento e vocalização.

Os indivíduos da espécie em estudo (cães) apresentam uma variabilidade fenotípica relativamente importante, de tal forma que é possível distinguí-los por meio da observação de suas características físicas (WHO; WSPA, 1990; Pal et al., 1998a, Pal et al., 1998b). Fato semelhante ocorre com outras espécies animais, como algumas espécies de mamíferos marinhos, nas quais a caracterização dos indivíduos se baseia na observação das nadadeiras, que por sua vez apresentam cicatrizes e molduras diferentes em cada animal (Barão-Acuña, 2002; Zeh et al., 2002), e de felinos silvestres, em que cada indivíduo é distinguido pela diferenciação dos desenhos das listras ou de manchas (Karanth, 1995; Carbone et al., 2001; Silver et al., 2004). Com relação ao cão, há estudos em que a simples observação dos animais foi utilizada como critério para distinguir os indivíduos entre si (Childs et al., 1998; Pal et al., 1998a; Pal et al., 1998b; Campos, 2004).

No geral, a técnica de captura-recaptura é considerada exeqüível, não exige mão-de-obra especializada e pode ser utilizada em diversas realidades (WHO; WSPA, 1990; Matos et al, 2002; Sallum, 2005). 


\subsection{Métodos de controle populacional}

As medidas de controle da população canina dependerão da ecologia e da biologia dos animais e das condições socioculturais e econômicas da comunidade (Reichmann et al., 2000b). Em especial, as estratégias devem ser baseadas na remoção de cães soltos nas vias públicas, no controle da movimentação e da reprodução de cães domiciliados e no controle do ambiente dos irrestritos (Beran; Frith, 1988; WHO; WSPA, 1990).

Entre os meios pelos quais essas atividades são executadas tem-se a criação de leis, a divulgação de informações e a educação em posse responsáel (WHO; WSPA, 1990). Logo, as estratégias para o controle da população canina se baseiam em uma ação conjunta entre a comunidade, as instituições governamentais responsáveis e a aplicação de leis (Feldmann, 1974; Reichmann et al., 2000b; Sallum, 2005).

A eliminação do excedente é realizada por meio da eutanásia. A título de exemplo, os cães recolhidos das vias públicas pelos serviços governamentais competentes e, por vezes, os animais entregues pelos proprietários aos CCZs usualmente são os animais alvo (Reichmann et al., 2000b). Embora a eutanásia seja um método de efeito imediato sobre o tamanho da população (Beran; Frith, 1988), se outros fatores que interferem na modulação da dinâmica populacional não forem controlados (oferta de alimento e abrigo, acesso dos cães às ruas, geração de crias indesejadas), o efeito da eutanásia será curto (pois haverá reposição da população por 
outros animais, seja por reprodução ou por imigração) e mais esforço ${ }^{12}$ deverá ser realizado para manter a população a níveis aceitáveis (WHO; WSPA, 1990; Reichmann et al., 2000b). Além disso, dependendo da zoonose a ser controlada, a eliminação de cães surtirá pequeno efeito (Palatinik-de-Sousa et al., 2004). Portanto, a remoção não é um método efetivo de controle populacional, mas é um auxílio para educação sobre a posse responsável (WHO; WSPA, 1990; Reichmann et al., 2000b). Além disso, a eliminação de cães pela eutanásia mostra ser um método aceitável em alguns locais e não em outros, segundo pesquisas de opinião pública (Beran; Frith, 1988; Gomes et al., 2004; Thursfield, 2004).

O controle reprodutivo mais eficaz é a castração cirúrgica dos animais (WHO; WSPA, 1990; Sallum, 2005).

Atualmente, algumas entidades governamentais e ONGs têm oferecido o serviço de castração a custos reduzidos para a população de baixa renda. Apesar de a castração ser de efeito mais duradouro, inicialmente pode não ser sentido o efeito da redução populacional, pois o número de indivíduos permanece inalterado (Feldmann, 1974). Ou seja, uma parcela dessa população submete-se à castração e em seguida é reintegrada. Contudo, considerando que o problema da superpopulação canina não está nela em si (mas na negligência dos proprietários) (Soto, 2003), os programas de castração a baixo custo serão irrelevantes para solucionar o problema (Feldmann, 1974). Além disso, tendo em vista o controle da população de cães, a castração em cadelas é mais interessante

\footnotetext{
12 Por esforço, neste caso, entende-se pelo uso de recursos humanos (mão-de-obra) e econômicos, de infra-restrutura, de tempo, além de outros itens que poderiam ser inclusos para a execução dessa tarefa.
} 
do quem em cães, já que as fêmeas são as que geram o(s) novo(s) indivíduo(s). Neculqueo Cáceres (2004) comenta em seu trabalho que para sistemas de acasalamento do tipo poligâmico, como no caso da espécie canina, o efeito da esterilização de machos é mínimo. Por fim, ainda há em algumas culturas informações equivocadas sobre os efeitos adversos da castração (como por exemplo, alterações sobre a masculinidade dos machos), o que dificulta a adesão dos proprietários (WHO; WSPA, 1990).

O controle da mobilidade é importante tanto para castrados quanto para não castrados, pois se evita a formação de bandos que se expõe a uma ampla gama de doenças (Reichmann et al., 2000b). Embora as atividades educativas sejam recomendadas e aplicadas em muitas atividades de controle desta população, ela nem sempre se torna praticável, principalmente nas classes sociais mais baixas (Beran; Frith, 1988).

Cães habitam vários tipos de habitats. As análises desses habitats revelam a abundância, distribuição e a predileção de recursos. Uma vez que esses recursos que determinam a capacidade de suporte do meio são conhecidos, torna-se possível controlar a abundância de cães manejando o habitat por meio da remoção da fonte de alimento (WHO; WSPA, 1990; Reichmann et al., 2000b). Beran e Frith (1988) relatam que a disponibilidade de alimentos é o principal fator limitante para a densidade populacional.

Contudo, para que o método de controle populacional seja bem executado e apresente resultados satisfatórios, é necessário que os métodos de controle acima comentados sejam mesclados e que a comunidade participe ativamente, principalmente em termos de 
responsabilidade sobre posse dos animais (por exemplo, restringindo a movimentação deles, castrando-os, planejando a disponibilidade do proprietário - em termos financeiro, de tempo, de infra-estrutura - em criar os animais). Além disso, leis que regulamentem a criação e posse de cães são necessárias e devem ser respeitadas (Reichmann et al., 2000b).

\subsection{Legislação}

Em todo o mundo, milhares de seres humanos criam cães em suas casas, geralmente como animais de estimação. Este convívio provém de longa data, desde os primórdios da antigüidade. São assim considerados animais domésticos, aqueles de convívio do ser humano, dele dependentes, e que não repelem o jugo humano (São Paulo, 2005). Ainda, sendo definidos como animais, a Declaração Universal dos Direitos dos Animais proclama que todos os animais nascem iguais diante da vida e têm o direito à existência, ao respeito, à consideração, à cura e à proteção do homem e que os seus direitos devem ser definidos por leis (UNESCO, 1978). Seguindo esta mesma linha de argumento, a lei federal 9.605, de 12 de fevereiro de 1998, em seu artigo 32, considera crime contra a fauna a prática de abuso, maus-tratos, ferir ou mutilar animais silvestres, domésticos ou domesticados, nativos ou exóticos.

De acordo com a Constituição Federal de 1988:

Art. 196. A saúde é direito de todos e dever do Estado, garantindo mediante políticas sociais e econômicas que visem a 
redução do risco de doença e de outros agravos e ao acesso universal e igualitário às ações e serviços para a promoção, proteção e recuperação.

Assim, conforme já foi introduzido anteriormente, o descontrole populacional canino tem potencial para gerar agravos sobre a saúde dos seres humanos e, considerando essa situação, o poder público tem o dever de interferir por meio de políticas públicas adequadas para a redução desse risco.

Considerando que os cães são animais que acessam livremente as vias públicas e que são ativos poluidores ambientais, torna-se necessário o exercício de atividades de controle populacional por meio de forças legislativas e sociais (Beck, 1975; Ciampo et al., 2000).

No Brasil, e em vários países no mundo, existem leis que regem a criação desses tipos de animais, com a finalidade de se obter um convívio mais harmonioso e agradável (Wanderler et al., 1993). Tais leis descrevem sobre a regulamentação da posse responsável e da proteção contra abusos e maus tratos. Dentro deste contexto, há legislações de âmbito federal, estadual e municipal.

Tomando como exemplo o Estado de São Paulo, pode-se observar que este tem lidado para com a questão do controle populacional canino pela elaboração da Lei Estadual no 11.977 de 25 de agosto de 2005. Segundo esta lei, os Municípios do Estado devem manter programas permanentes de controle de zoonoses, através de vacinação e controle de 
reprodução de cães e gatos, ambos acompanhados de ações educativas para propriedade ou guarda responsável.

Seguindo esta linha de conduta e utilizando-se de meios legais, vários municípios têm elaborado leis com o propósito de regulamentar a posse responsável de cães e de gatos e de outras providências.

A título de exemplo, em Ibiúna-SP, desde o ano de 2004, tem sido regulamentado o sistema de Registro Geral Animal de caráter compulsório; a campanha de vacinação anti-rábica para cães e gatos; as orientações técnicas sobre condução de cães em vias e logradouros públicos (uso de coleira e de guia, além do recolhimento dos dejetos lançados pelos animais nas vias públicas); as condições mínimas para a manutenção da saúde e do bem-estar animal; a política de recolhimento de animais irrestritos e a de proteção animal contra maus tratos de diversas naturezas; e o programa de castração de cães e de gatos (Ibiúna, 2004, 2005).

No Município de São Paulo, por sua vez, a lei municipal 13.131/2001 foi elaborada com a finalidade de reforçar por meios legais a disciplina sobre a criação, propriedade, posse, guarda, uso e transporte de cães e gatos. Assim, semelhante ao que ocorre em lbiúna/SP, essa lei determina que um animal é de responsabilidade do dono; que é obrigatório manter o animal domiciliado, alimentado, higienizado, vacinado contra raiva; que é obrigatório recolher os dejetos de animais de estimação em área pública; que é proibido abandonar animais; que é proibido maltratar os animais; e que é de responsabilidade do dono qualquer agressão em pessoa ou animal provocada por animal de sua propriedade. 
O Centro de Controle de Zoonoses do Município de São Paulo tem desenvolvido desde 2002 o programa de educação continuada "Para Viver de Bem com os Bichos" (que já contabilizou a participação de 1146 Unidades Educacionais da rede municipal, estadual e particular de ensino até 0 ano de 2005), em que professores das escolas participantes são capacitados a trabalharem as informações colhidas em curso específico promovido pelo programa com os seus alunos por meio de atividades pedagógicas. Entre os objetivos esperados, além do incentivo à posse responsável desses animais, estão a educação ambiental e humanitária (São Paulo, 2006).

O incentivo à posse e propriedade responsável de animais tende a auxiliar também nos casos de acidentes por agressão por cães e gatos. No caso de agravos a terceiros, segundo o Código Civil (Brasil, 2002), Art. 936, "o dono, ou detentor, do animal ressarcirá o dano por este causado, se não provar culpa da vítima ou força maior". 


\section{MÉTOdOS}

\subsection{Criação dos catálogos fotográficos experimentais}

A foto-identificação foi a técnica de marcação eleita para este trabalho e justifica-se por ser prática, quando utilizada em campo, e não invasiva em relação aos animais (Sallum, 2005; WHO; WSPA, 1990). Além disso, esta é a técnica recomendada pela WHO e WSPA (1990) para dimensionamento de população canina nas ruas (a WHO e a WSPA, em 1990, apresentam o método de captura-recaptura fotográfica por Método de Beck). No caso deste trabalho, o uso da foto-identificação também se justifica por oferecer menor risco de injúrias aos pesquisadores (com relação ao manejo de animais amostrados) e por diminuir o contato com cães de procedência desconhecida.

A priori, as fotos obtidas dos cães do setor de adoção do CCZ tiveram como objetivos estimar as probabilidades de identificação e de individualização dos cães por meio da observação de registros fotográficos, além de analisar o grau de concordância dos resultados entre os observadores e o padrão ouro ("gold standard"). Como houve total controle das fotos obtidas nesta etapa, logo foi possível de se estabelecer o "gabarito" dos conjuntos de fotos a serem apresentadas aos voluntários, no que se refere entre ter sido ou não o mesmo animal nas fotografias.

Há trabalhos relacionados à eficiência de armadilhas fotográficas para animais silvestres (Carbone et al., 2001; Srberk-Araujo; Chiarello, 2005), 
onde foram estudados quais são as posições ideais para fixá-la, visando obter a otimização da coleta de dados (fotografias) da população alvo. Neste caso, obteve-se a maximização da obtenção de fotografias em função da alocação das câmeras. Paralelamente, há trabalhos em que é relatada obtenção de fotografias de baixa qualidade e discutido o uso delas (BarãoAcuña, 2002; Maffei et al., 2005).

A criação do catálogo fotográfico padrão ${ }^{13}$ (utilizado para calibrar a técnica de foto-identificação e avaliar as probabilidades de identificação de cães) envolveu os seguintes materiais e recursos:

- Câmera fotográfica digital (Sony FD Mavica, modelo MVCFD97);

- 30 Cães (sem padrões de raça definidos) para serem fotografados como modelos (esses se encontravam internados no canil de adoção do CCZ);

- Um cambão para contenção dos cães (cedido pelo próprio CCZ);

- Uma corrente prateada, leve, resistente e de grande extensão (cerca de 05 a 10 metros de comprimento), que não apresentasse riscos de lesão aos animais;

- Voluntários para identificação dos cães pelas fotografias.

O processo de obtenção das fotografias seguiu quatro diferentes protocolos, que, por conseqüência, originaram quatro tipos diferentes de

\footnotetext{
${ }^{13}$ Tal catálogo fotográfico padrão, ao longo do texto, poderá ser referido como catálogo experimental, por utilizar fotografias de cães em uma situação experimental (simulada).
} 
catálogos ${ }^{14}$ fotográficos. Cada um dos 30 animais fotografados teve dois conjuntos $^{15}$ de fotografias obtidas, sendo que cada conjunto foi composto por uma ou no máximo quatro fotografias, dependendo do protocolo seguido. Portanto, cada protocolo foi composto por 60 conjuntos de fotografias.

O cão doméstico é uma espécie animal com características fenotípicas bastante variadas (Hafez, 1982; Beck, 2002). Assim, com a finalidade de se aproveitar desse fato, os quatro protocolos foram elaborados com o propósito de tornar este fator favorável para a identificação e para a detecção de diferenças entre os critérios de criação dos catálogos seguidos. Os critérios para a criação dos catálogos foram os seguintes:

- Catálogo A: o animal foi fotografado sem seguir nenhum tipo de padrão ou referência. A posição do animal, o distanciamento em relação ao fotógrafo e o ângulo de obtenção da fotografia foram os mais variados possíveis. Cada conjunto de fotografias foi composto por uma foto (Figura 2).

\footnotetext{
${ }^{14}$ Por catálogo, neste caso, entende-se por um grupo de conjunto de fotos que foram obtidas a partir de um mesmo protocolo.

${ }_{15}$ Por conjunto, neste caso, entende-se por um grupo de fotos, obtidas em um mesmo momento, de um mesmo animal.
} 


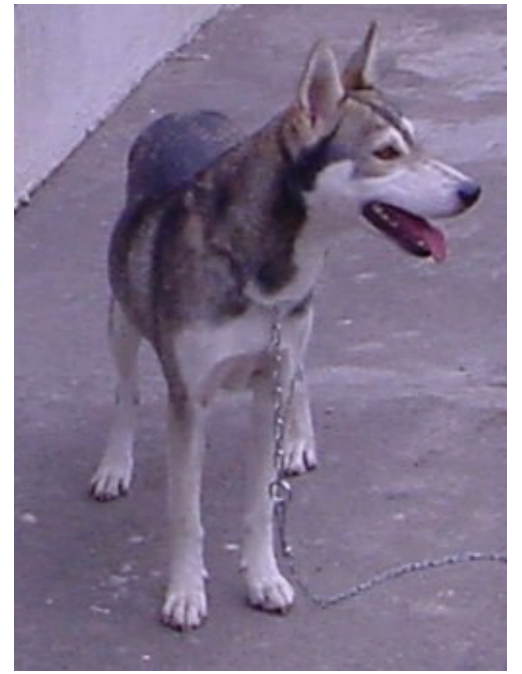

Figura 2: Exemplo de um conjunto de fotos do catálogo A.

- Catálogo B: o animal foi enquadrado na fotografia sob a visualização crânio-lateral. Cada conjunto de fotografias foi composto por uma foto (Figura 3).

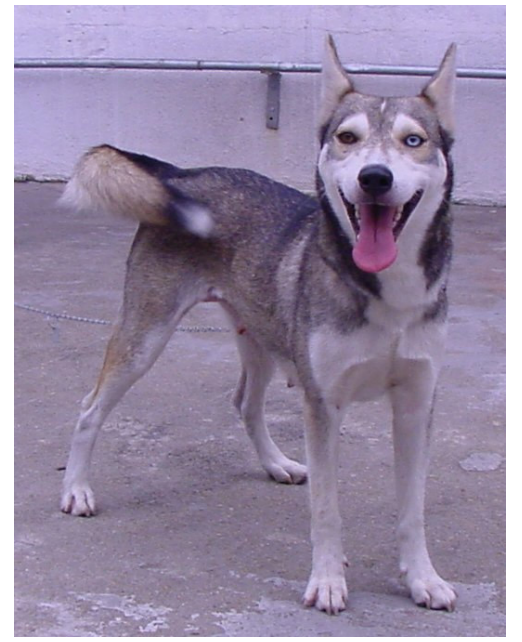

Figura 3: Exemplo de um conjunto de fotos do catálogo B.

- Catálogo C: o animal foi fotografado por três ângulos diferentes (crânio-lateral direito e esquerdo e dorso-caudal), gerando um 
conjunto de três fotos. Durante a execução do experimento (cujo procedimento será apresentado no próximo item), cada conjunto de fotos referente a este catálogo teve suas três fotografias simultaneamente apresentadas, com a finalidade de informar ao voluntário que as três fotos correspondiam ao mesmo animal e, assim, possibilitar uma observação quase completa do físico do cão (Figura 4).
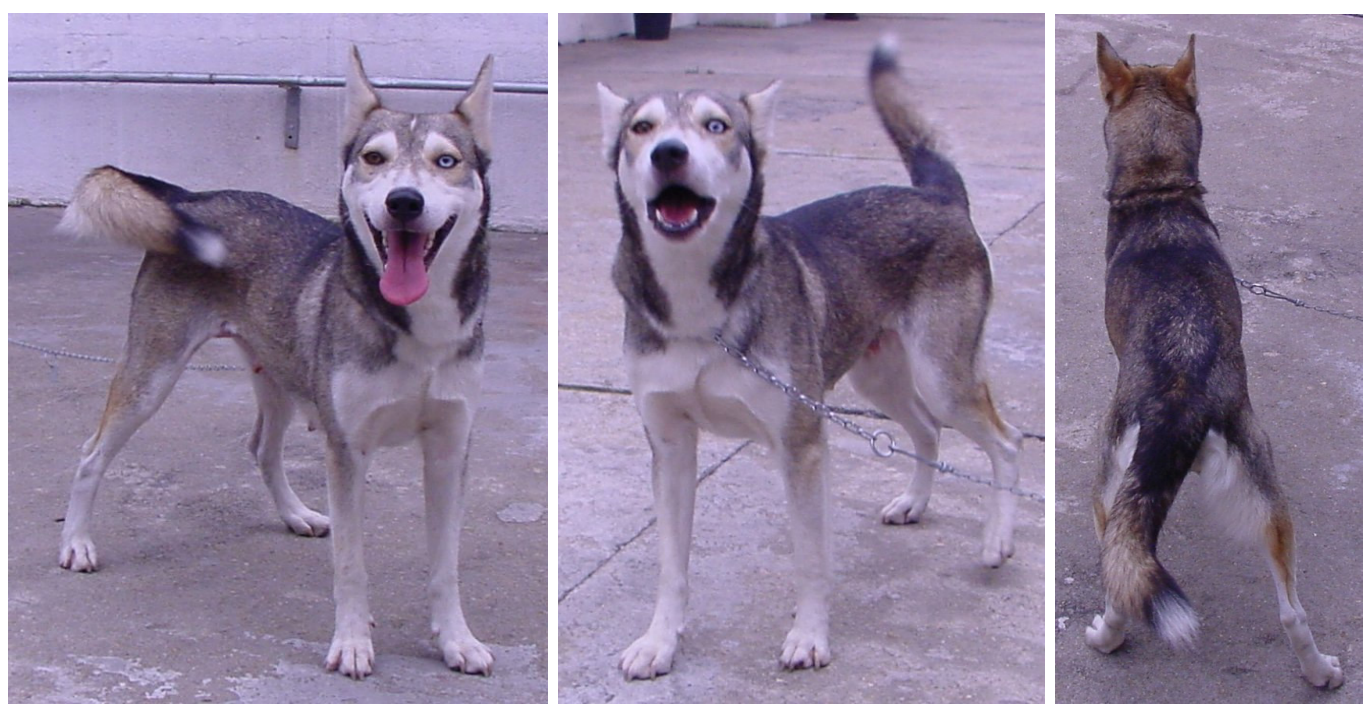

Figura 4: Exemplo de um conjunto de fotos do catálogo C.

- Catálogo D: o animal foi fotografado por quatro ângulos diferentes referentes aos seus quatro perfis (cranial, lateral direito e esquerdo, caudal). A idéia das quatro fotos foi a mesma do protocolo de três fotos, ou seja, observação quase total do animal. Cada conjunto de fotografias foi composto por quatro fotos (Figura 5). 

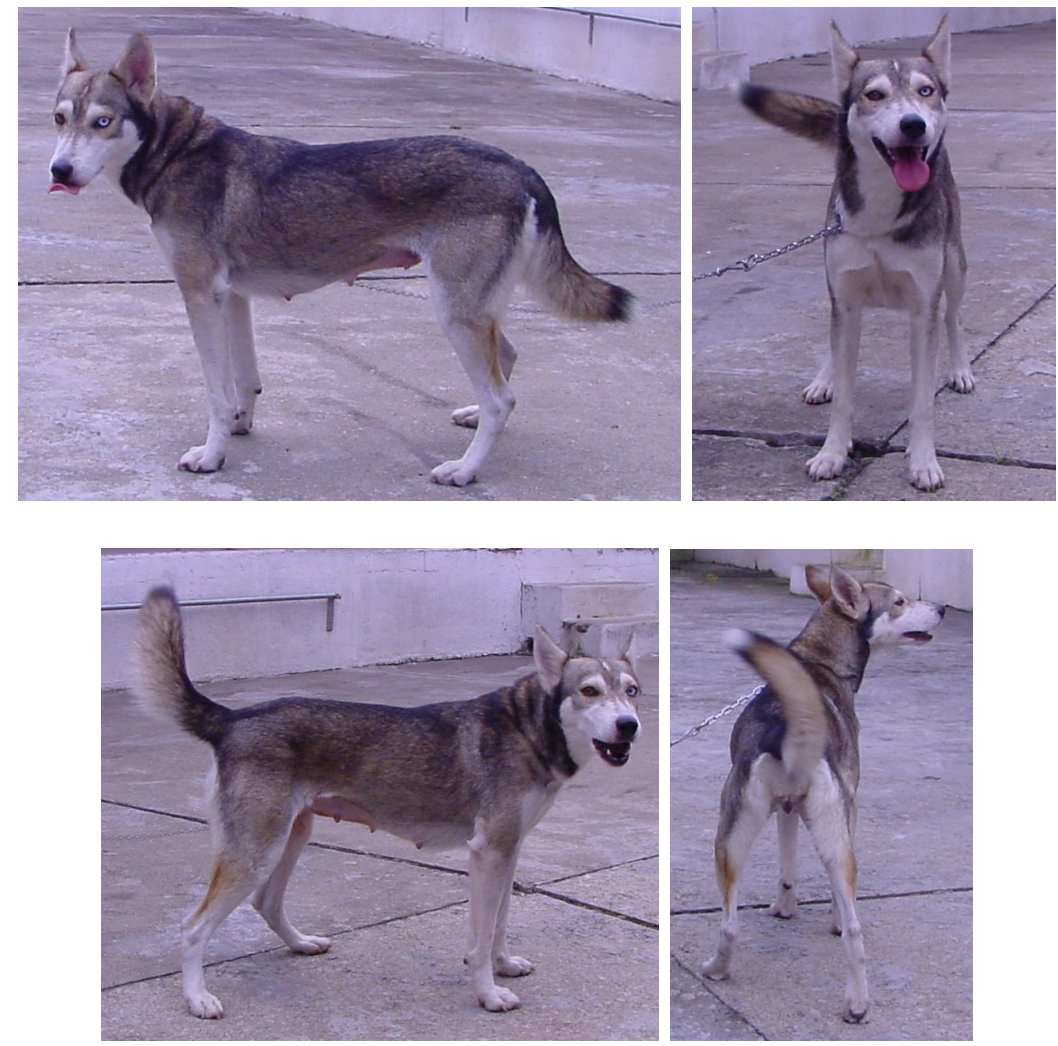

Figura 5: Exemplo de um conjunto de fotos do catálogo D.

Por meio de um editor de imagem (Jasc Paint Shop Pro ${ }^{\mathrm{TM}}$ Version 6.01) o tamanho das fotografias obtidas foram redimensionadas e centralizadas ao máximo sobre a imagem do cão.

A idéia de se obter mais de uma foto de um mesmo animal foi baseada em relatos de trabalhos onde mais de uma armadilha fotográfica foi disposta tal forma que se obtivesse registros fotográficos de ambos os lados do corpo dos animais em estudo (Silver et al., 2004).

As fotografias dos animais foram organizadas conforme o esquema representado pelo Quadro 2. 
Quadro 2: Apresentação esquemática da organização das fotos obtidas experimentalmente a partir dos cães do CCZ. Cada cão utilizado como modelo foi identificado por um número (n) para fins de controle e organização.

\begin{tabular}{|c|c|c|c|}
\hline \multirow{8}{*}{ Cão (n) } & \multirow{2}{*}{ Catálogo A } & Conjunto 1 & fotocão01 \\
\hline & & Conjunto 2 & fotocao02 \\
\hline & \multirow{2}{*}{ Catálogo B } & Conjunto 3 & fotocao03 \\
\hline & & Conjunto 4 & fotocao04 \\
\hline & \multirow{2}{*}{ Catálogo C } & Conjunto 5 & $\begin{array}{l}\text { fotocao0 } 05 \\
\text { fotocao06 } \\
\text { fotocao07 }\end{array}$ \\
\hline & & Conjunto 6 & $\begin{array}{l}\text { fotocao } 08 \\
\text { fotocao09 } \\
\text { fotocao } 10\end{array}$ \\
\hline & \multirow{2}{*}{ Catálogo D } & Conjunto 7 & $\begin{array}{l}\text { fotocao11 } \\
\text { fotocao12 } \\
\text { fotocao13 } \\
\text { fotocao14 }\end{array}$ \\
\hline & & Conjunto 8 & $\begin{array}{l}\text { fotocao } 15 \\
\text { fotocao16 } \\
\text { fotocao } 17 \\
\text { fotocao18 }\end{array}$ \\
\hline
\end{tabular}

\subsection{Levantamento dos dados a campo no município de lbiúna: criação dos catálogos fotográficos obtidos em campo}

Além da obtenção de catálogos experimentais (cães do CCZ), foram obtidas fotografias em estudo realizado a campo. Para o estudo de campo, o local escolhido foi o bairro de Santa Lúcia - Ibiúna/SP.

O município de Ibiúna situa-se a $71 \mathrm{~km}$ da capital paulista, apresentando $1.060 \mathrm{~km}^{2}$ e população estimada em $1^{0}$ de julho de 2005 de 73.905 habitantes. Ainda, há aproximadamente 16.637 domicílios e de 18.477 cães domiciliados (Soto, 2003; IBGE, 2007).

O bairro de Santa Lúcia (popularmente conhecido pelos ibiunenses por C.D.H.U. - Conjunto Habitacional Santa Lúcia) apresenta área total 
aproximada de $88.942 \mathrm{~m}^{2}, 190$ domicílios e aproximadamente 845 habitantes segundo o Serviço de Regularização de Loteamentos e Arruamentos da Prefeitura da Estância Turística de Ibiúna (SERLA) e IBGE (2007). Os limites geográficos aproximados se encontram na Tabela 2. Este local foi escolhido devido ao fácil acesso, ao percurso relativamente simples do bairro e por ser de pequena extensão territorial (Figuras 6 e 7).

Tabela 2: Posição geográfica aproximada dos limites norte, sul, leste e oeste do Bairro Conjunto Habitacional Santa Lúcia (Ibiúna/SP).

\begin{tabular}{ccccc}
\cline { 2 - 4 } & \multicolumn{4}{c}{ Limites } \\
\cline { 2 - 5 } & Norte & Sul & Oeste & Leste \\
\hline Altitude & $851 \mathrm{~m}$ & $863 \mathrm{~m}$ & $857 \mathrm{~m}$ & $860 \mathrm{~m}$ \\
Latitude & $23^{\circ} 39^{\prime} 48.70^{\prime \prime S}$ & $23^{\circ} 40^{\prime} 0.15^{\prime \prime S}$ & $23^{\circ} 39^{\prime} 54.27^{\prime \prime} \mathrm{S}$ & $23^{\circ} 39^{\prime} 54.27^{\prime \prime S}$ \\
Longitude & $47^{\circ} 13^{\prime} 47.30^{\prime \prime} \mathrm{W}$ & $47^{\circ} 13^{\prime} 47.30^{\prime \prime} \mathrm{W}$ & $47^{\circ} 13^{\prime} 59.20^{\prime \prime} \mathrm{W}$ & $47^{\circ} 13^{\prime} 37.02^{\prime \prime} \mathrm{W}$ \\
\hline Fonte: Google Earth & & &
\end{tabular}

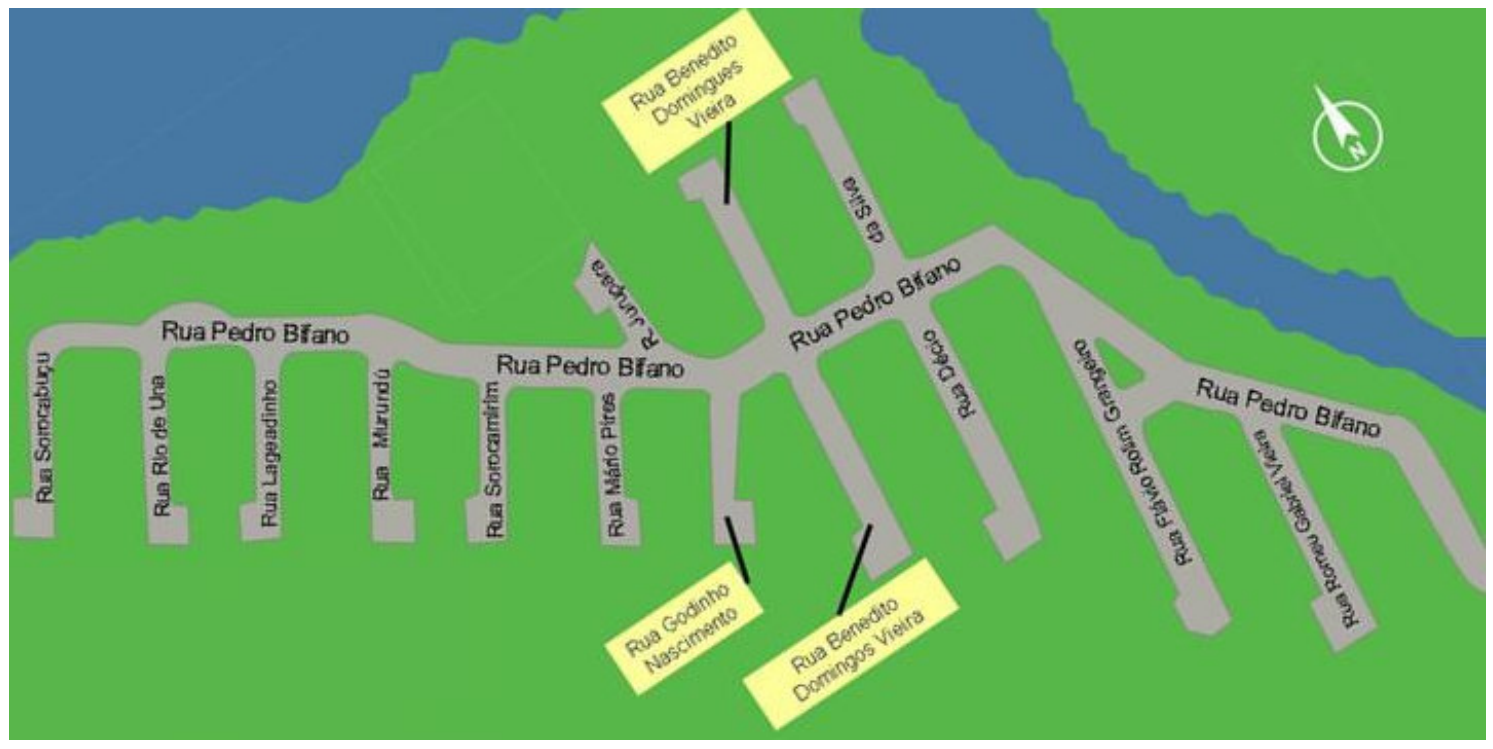

Figura 6: Bairro Conjunto Habitacional Santa Lúcia (Ibiúna/SP). Imagem meramente ilustrativa e esquemática (Fonte: SERLA). O levantamento de dados foi realizado apenas sobre as ruas do bairro (delimitados pela cor cinza). 

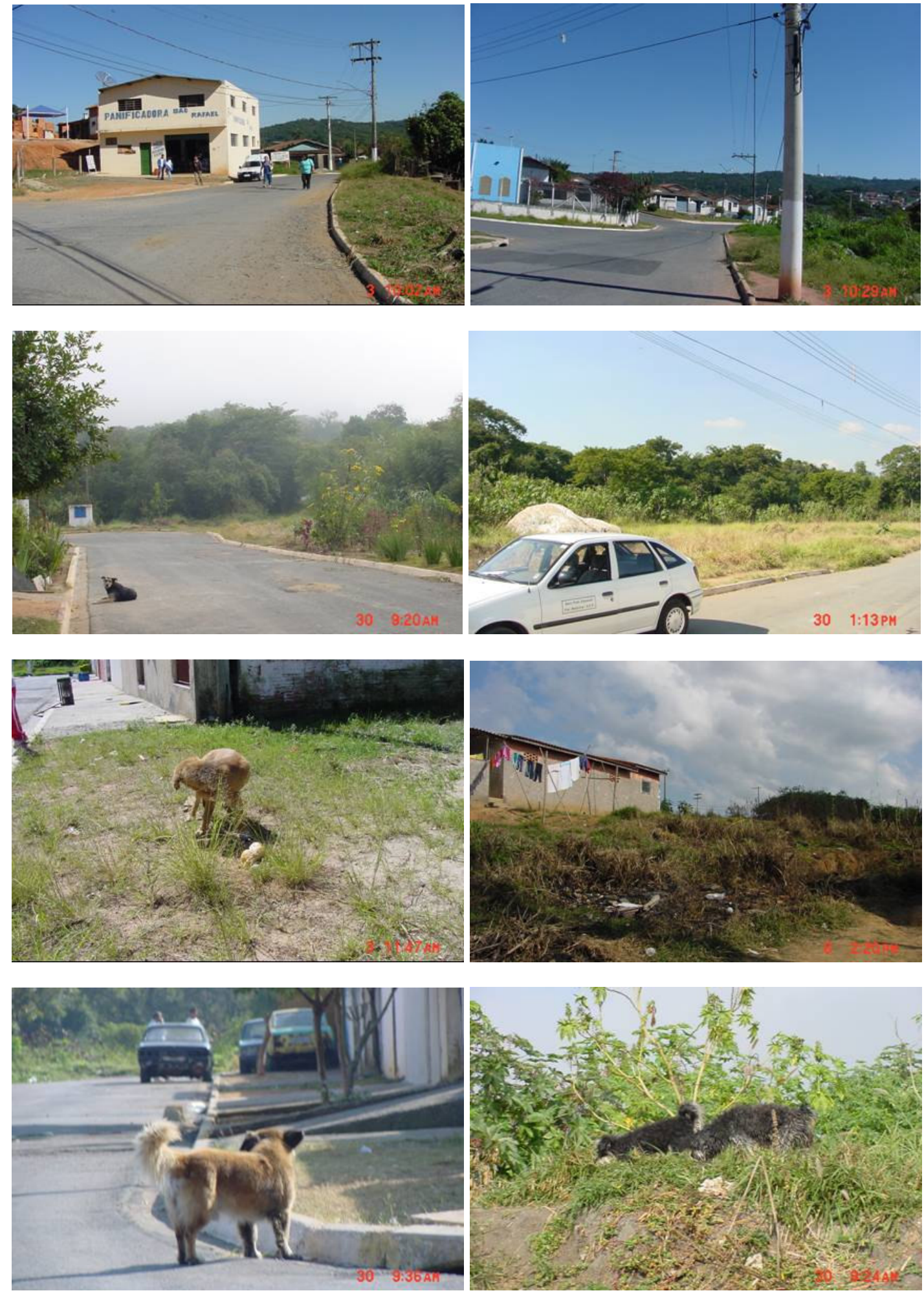

Figura 7: Fotos ilustrativas do bairro Conjunto Habitacional Santa Lúcia (Ibiúna/SP). 
Nesta etapa, em que foi aplicado o método de captura-recaptura fotográfica, os materiais e recursos necessários foram:

- Câmera fotográfica digital (Sony FD Mavica, modelo MVCFD97);

- Um veículo;

- Um cambão para contenção dos animais (visando possíveis situações de risco);

- Bloco de notas para anotações que fossem pertinentes e formulários específicos para levantamento de dados complementares (Anexos A e B).

O veículo e o motorista foram cedidos pela própria Faculdade de Medicina da Universidade de São Paulo.

O protocolo de execução desta etapa da pesquisa foi próximo ao descrito e pela WHO e WSPA (1990) e por Sallum (2005). Enquanto este utilizou a técnica clássica (White et al., 1982; Amstrup et al., 2005), no presente trabalho foi realizado três amostragens em três visitas ao bairro (considerando uma visita por semana), sendo que em cada visita o bairro foi percorrido duas vezes.

Considerando o fato desse bairro escolhido ter sido um local nunca antes visitado e, também, havendo a possibilidade de existir alguma (mesmo que ligeira) diferença nas coletas de dados entre as primeiras visitas em relação às seguintes, foi efetuado um reconhecimento prévio do local, a fim de permitir que o pesquisador estivesse em condições justas em relação ao bairro. Esta visita piloto foi realizada no período de um dia, em que se 
estimou o tempo médio gasto para percorrer o percurso, a quilometragem média percorrida e as condições do local. Todos estes parâmetros previamente calculados foram importantes para o planejamento e a programação das visitas a esse bairro, no sentido de se estimar a duração da coleta de dados, o horário para saída da Faculdade de Medicina, entre outros fatores.

Nos dias agendados, as saídas da Faculdade de Medicina foram marcadas para as 07:00 h, com chegada ao bairro Santa Lúcia (Ibiúna/SP) por volta das 08:30 h. No primeiro dia de buscas, com a finalidade de familiarizar o motorista com o percurso, inicialmente foi solicitado que este o percorresse em velocidade média de $20 \mathrm{~km} / \mathrm{h}$.

Foi solicitado ao motorista que entrasse em cada rua até o seu final, fizesse a baliza com o veículo e voltasse por ela mesma. Esta orientação foi executada no sentido "ida", em todas as ruas, assim como no sentido "volta". Dessa forma, cada rua foi percorrida duas vezes (uma na "ida" e uma na "volta", totalizando quatro vezes) em cada percurso. Em média, cada percurso teve duração de duas horas, percorrendo-se cerca de $05 \mathrm{~km}$ de trajetória (somando a "ida" e a "volta").

Por visita agendada, foram realizados dois percursos, sendo um no período da manhã $(08: 30 \mathrm{~h}$ às $10: 30 \mathrm{~h})$ e outro, no da tarde $(12: 00 \mathrm{~h}$ às 14:00 h). 
Durante a execução do percurso, foi observada atentamente a presença de $\operatorname{cães}^{16}$ no local. Ao encontrá-los livres nas vias públicas, foi solicitado ao motorista que parasse por um momento para que fossem fotografados. Procurou-se ao máximo obter o registro fotográfico tal que permitisse a observação mais completa possível do aspecto físico, a fim de se obter o melhor registro fenotípico deles. Cada oportunidade em que o animal foi encontrado na via pública (não importando o fato de ter obtido a sua fotografia ou não) é mencionado neste trabalho simplesmente por encontro.

Neste estudo, não houve tentativa de diferenciar os cães sem dono daqueles com donos. O objetivo foi o de estimar quantos cães livres estiveram presentes nas ruas do bairro.

Independente da circunstância do encontro (isto é, da dificuldade de se obter a fotografia ou mesmo do fato de ele ter sido ou não fotografado), informações adicionais foram coletadas em formulário específico, semelhante à idéia posta em prática por Daniels e Bekoff (1989) (Anexos A e B). A finalidade destas informações foi a de resgatar informações que possam ser interessantes para auxiliar na identificação dos cães pelas fotografias (processo de foto-identificação). A título de exemplo, sabe-se que os cães apresentam características referentes ao seu hábito territorial (Daniels; Bekoff, 1989) e, portanto, o registro do endereço onde foi

\footnotetext{
${ }^{16}$ Foram fotografados os cães que estivessem soltos nas ruas, sem a apresentação de proprietários que os conduzissem por meio de coleira e guia. Beck (2002) em seu estudo define os cães livres nas ruas como qualquer cão sem supervisão humana imediata, tanto nas propriedades públicas quanto privadas, e/ou que tenham acesso livre e irrestrito da propriedade privada para a pública.
} 
encontrado ou mesmo de algum ponto de referência podem auxiliar na sua identificação.

Por meio de um editor de imagem (Jasc Paint Shop Pro ${ }^{\mathrm{TM}}$ Version 6.01) o tamanho das fotografias obtidas foram redimensionadas e centralizadas ao máximo sobre a imagem do cão.

Terminados os três dias de levantamento de dados, as fotografias obtidas foram armazenadas e organizadas em formato digital. As fotografias obtidas de cada encontro foram organizadas em conjuntos, conforme a sua semelhança com os catálogos A, B, C e D apresentados na etapa experimental.

Por vezes, o mesmo encontro possibilitou a elaboração de diversos catálogos, dependendo da quantidade e da qualidade das fotografias obtidas. As informações registradas nos formulários também auxiliaram na organização e na manipulação delas. Os grupos de encontros, por sua vez, foram organizados de acordo com o período em que foi amostrado (manhã ou tarde) e o dia (primeiro, segundo ou terceiro dia).

Esquematicamente, a sistemática de organização descrita para as fotografias obtidas nas ruas do bairro de Santa Lúcia está representado no Quadro 3. 
Quadro 3: Apresentação esquemática da organização das fotos obtidas da amostragem realizada a campo.

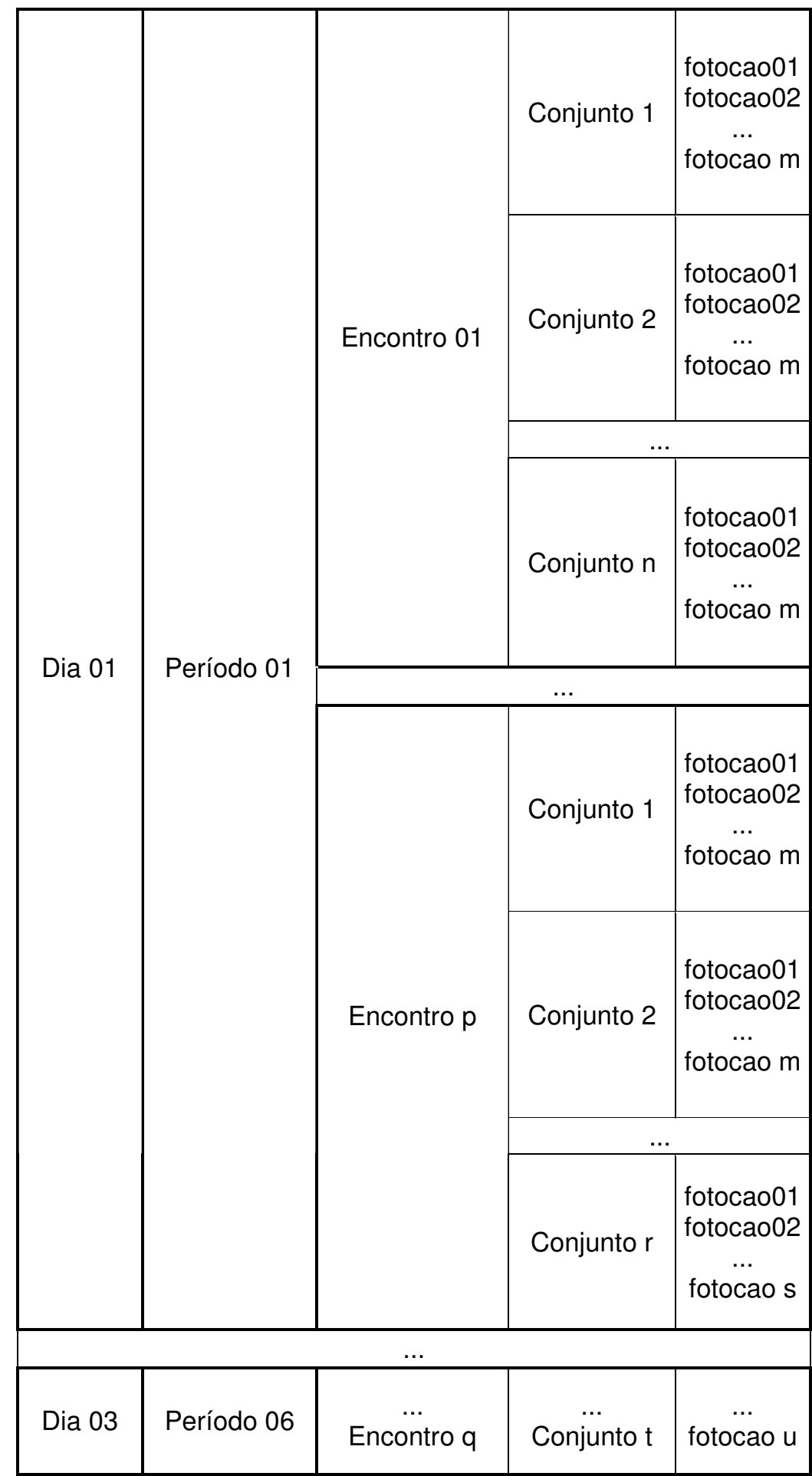




\subsection{Participação de voluntários para a identificação dos cães por meio da observação dos catálogos}

A experiência prática demonstra que o registro fotográfico do cão envolve algumas dificuldades operacionais. Entre elas, podem ser lembradas: a posição do animal, a distância em relação ao fotógrafo, a movimentação de ambos e o ângulo de visão. Estes fatores são importantes para a determinação da qualidade da fotografia e da apresentação do animal nela.

Considerando o argumento acima, se um mesmo animal for fotografado em mais que uma oportunidade, há a probabilidade de essas fotografias não seguirem o mesmo padrão. Ao contrário, elas poderão seguir padrões diferentes.

O estudo da observação das fotografias de cães envolveu tanto o uso das fotos obtidas dos animais do $\mathrm{CCZ}$, quanto àquelas obtidas do levantamento de dados a campo.

Esta etapa contou com a participação de 103 voluntários, que foram orientados a observar os pares de conjunto de fotografias de cães apresentados e indicar se, na opinião deles, correspondiam ou não ao mesmo animal. A participação dos voluntários neste experimento foi aberta a todas as pessoas, sem restrição de perfil, tais como idade, formação, sexo, ou qualquer outro tipo de condição que fosse considerada pré-requisito. 


\subsubsection{Observação dos catálogos de fotografias dos cães do CCZ}

A fim de avaliar a técnica fotográfica diante de quatro combinações de padrões fotográficos, foi realizada uma avaliação das probabilidades de identificação de cães a partir das fotografias obtidas de cães internados no CCZ de São Paulo/SP. Dessa forma, criou-se uma situação experimental contendo o padrão ouro para a técnica, uma vez que, nesta situação, há o controle de quais foram as fotografias que correspondiam ao mesmo animal.

A fim de tornar a compreensão do trabalho mais objetiva e simplificada, foram adotados os seguintes termos:

- $P_{(\text {parlpar efetivo })}$ : para a probabilidade de indicar corretamente que um par de conjuntos de fotos se trata de um mesmo animal, dado que era efetivamente o mesmo animal;

- $P_{(\text {não parlnão par efetivo) }}$ : para a probabilidade de indicar corretamente que um par de conjuntos de fotos não se trata de um mesmo animal, dado que efetivamente não era o mesmo animal;

- $\quad P_{(\text {parl par para o voluntário })}$ : para a probabilidade de indicar corretamente que um par de conjuntos de fotos se trata de um mesmo animal, dado que, sob a ótica do observador, era o mesmo animal;

- $P_{(n \tilde{a} o \text { parlnão par para ovoluntário) }}$ : para a probabilidade de indicar corretamente que um par de conjuntos de fotos não se trata de um mesmo animal, dado que, sob a ótica do observador, não era o mesmo animal. 
Para a avaliação destes quatro parâmetros foram utilizados tanto os pares quanto os não-pares de conjuntos de fotos.

A proporção entre pares e não pares efetivos a serem apresentados para cada voluntário foi a questão a ser solucionada. Teoricamente, poderíamos apresentar todos os pares possíveis para cada voluntário, entretanto, isso se tornaria extremamente cansativo e haveria uma grande possibilidade de recusas. Sendo assim, a idéia foi que cada voluntário avaliasse uma parcela dessa quantidade total, de tal forma que houvesse a tendência de que todos os pares e não pares fossem avaliados. Portanto, foi necessário que o número de pares apresentados para cada voluntário fosse otimizado.

Além disso, é de se imaginar que dificilmente as fotografias de cães obtidas a campo sigam um único padrão. Portanto, a idéia foi que os voluntários não avaliassem apenas pares de conjunto de fotos de único catálogo, mas também da combinação entre eles. Partindo da idéia de que cada um desses catálogos experimentais elaborado apresentou 30 animais distintos e que, portanto, há 60 conjuntos de fotos, a combinação entre os catálogos foi baseada na disposição de metade desses conjuntos (30, de tal forma que cada um deles correspondeu a um animal distinto) com a respectiva metade de outro catálogo (novamente 30 , sendo que cada conjunto representou um animal).

Sendo que cada uma das possíveis combinações entre os catálogos apresentou 60 conjuntos, foi determinado o universo de possibilidades de pareamento entre eles por meio de análise combinatória. Dessa forma, 
foram calculados 900 pares de conjuntos de fotografias dentro do universo de possibilidades de pareamento para cada combinação de catálogos (ou seja, $30^{2}$ ), sendo que 30 pares corresponderam aos 30 animais e 870 , às combinações de pares de conjuntos de fotografias diferentes entre esses 30 animais. Contudo, se considerarmos que a ordem entre os não-pares efetivos não importa, teríamos 465 pares possíveis no total $(30+870 / 2=$ 465). Novamente, pressupõe-se que a avaliação de todas essas possibilidades por uma única pessoa seria exaustiva, o que poderia até mesmo forçar a influência de vieses e incertezas de resultado muito elevado.

Pelo fato de o número de possibilidades de não-pares de conjunto de fotos ter sido maior que o de pares (435 e 30, respectivamente), considerouse que o número de pares como fator limitante para a determinação da proporção de pares e de não-pares de conjunto de fotos a serem apresentados aos voluntários. Além disso, houve uma maior flexibilidade de dispor os não-pares em relação aos pares.

Em primeiro lugar, foi necessário determinar quantos voluntários seriam necessários para avaliar os 30 pares efetivos ao menos uma vez e quantos pares (entre pares e não-pares) deveriam ser apresentados para cada um deles. Em termos esquemáticos, pode-se imaginar um diagrama em que as linhas correspondessem à seqüência de pares apresentados para cada voluntário (indicaremos essa linha por R) e a coluna, a seqüência de voluntários (adotaremos por S). Sabendo-se que os 30 pares estariam distribuídos nesse diagrama, logo, as suas dimensões ( $R$ e S) se ajustariam ao máximo oferecido por esse valor (30). 
Guidorizzi (2001) apresenta exemplos de aplicações do conceito de máximo e mínimo de funções. Um desses exemplos se refere à construção de um quadrilátero com o máximo de área possível dado certo limite de valores para os seus dois lados paralelos. Extrapolando a idéia desse exemplo para o problema em questão, suponhamos que a soma de dois lados perpendiculares seja $30(R+S=30)$ e que estamos em busca da área máxima possível desse quadrilátero (Área máxima = R.S). A área máxima obtida dentro dessas condições é 225 , correspondente ao par ordenado $(15,15)$. Qualquer outro par ordenado que satisfaça a relação $(R+S=30)$ proporciona um valor de área inferior.

Assim, para que todos os pares efetivos (dada uma certa combinação de catálogos) fossem avaliados ao menos uma vez, foram necessários 15 voluntários. Além disso, cada voluntário observou 15 pares de fotos. Sendo que há 30 pares efetivos e 15 voluntários para observá-los, ficou estipulado que cada voluntário avaliaria dois pares efetivos. Tomando por regra que foram avaliados tanto os pares quanto os não-pares e que cada voluntário avaliou uma parcela desses dois totais, os 13 pares restantes (do total de 15) foram completados por não pares efetivos escolhidos aleatoriamente.

A Figura 8 apresenta esquematicamente a descrição do método sugerido para esta etapa. 


\begin{tabular}{|c|c|c|}
\hline \multicolumn{3}{|l|}{ a) } \\
\hline Lado R & Lado S & R.S \\
\hline 0 & 30 & 0 \\
\hline 1 & 29 & 29 \\
\hline 2 & 28 & 56 \\
\hline 3 & 27 & 81 \\
\hline 4 & 26 & 104 \\
\hline 5 & 25 & 125 \\
\hline 6 & 24 & 144 \\
\hline 7 & 23 & 161 \\
\hline 8 & 22 & 176 \\
\hline 9 & 21 & 189 \\
\hline 10 & 20 & 200 \\
\hline 11 & 19 & 209 \\
\hline 12 & 18 & 216 \\
\hline 13 & 17 & 221 \\
\hline 14 & 16 & 224 \\
\hline 15 & 15 & 225 \\
\hline 16 & 14 & 224 \\
\hline 17 & 13 & 221 \\
\hline 18 & 12 & 216 \\
\hline 19 & 11 & 209 \\
\hline 20 & 10 & 200 \\
\hline 21 & 9 & 189 \\
\hline 22 & 8 & 176 \\
\hline 23 & 7 & 161 \\
\hline 24 & 6 & 144 \\
\hline 25 & 5 & 125 \\
\hline 26 & 4 & 104 \\
\hline 27 & 3 & 81 \\
\hline 28 & 2 & 56 \\
\hline 29 & 1 & 29 \\
\hline 30 & 0 & 0 \\
\hline
\end{tabular}

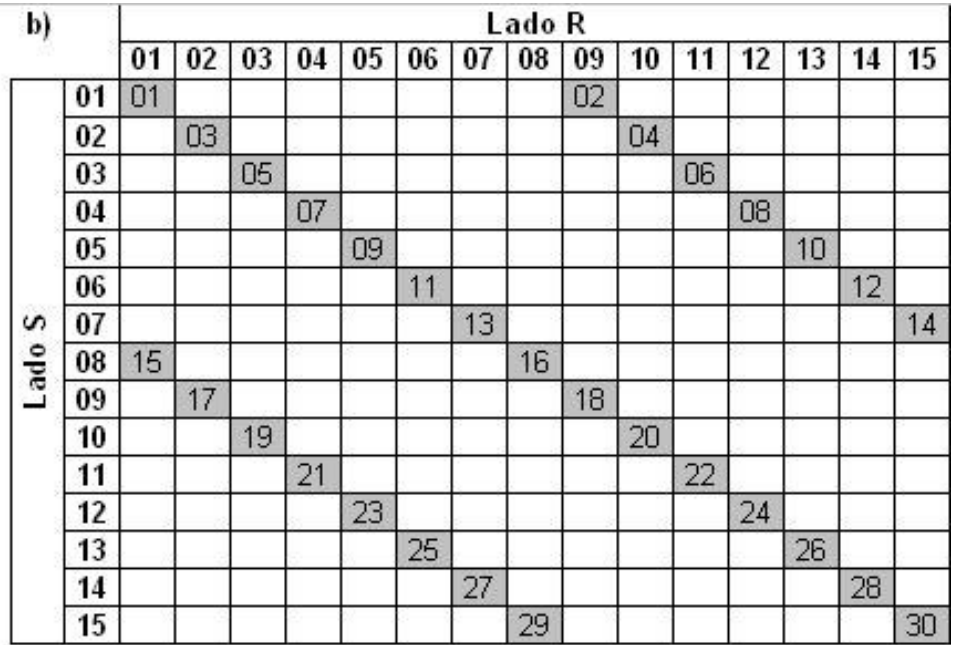

c)

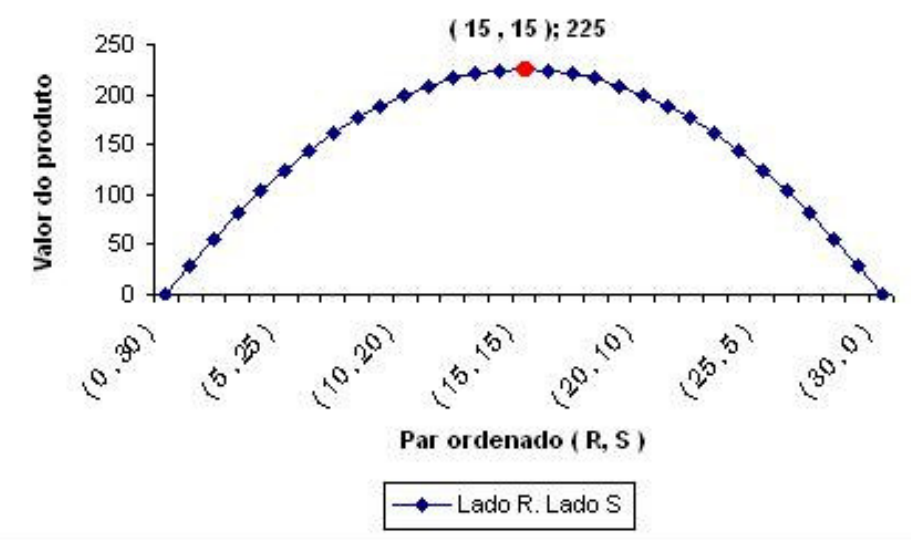

Figura 8: Apresentação esquemática da sistemática de apresentação de pares e de não pares de conjunto de fotos aos voluntários. Em (a) a descrição das várias configurações possíveis de disposição dos valores de $\mathrm{R}$ e $\mathrm{S}$ (vertical e horizontal) e as respectivas áreas de cada configuração. Em destaque, a configuração $15 \times 15$, que indica a área otimizada dentro dos limites máximos de R e S. Em (b) um exemplo de distribuição dos pares e nãopares de conjunto de fotos na área em questão. Os quadriculados em destaque (numerados de 01 a 30) correspondem à alocação dos conjuntos de pares efetivos; os quadriláteros em branco, à alocação dos conjuntos de não-pares; o Lado S, à seqüência dos voluntários e o Lado $\mathrm{R}$, à apresentação dos pares de conjunto de fotos para cada voluntário. Em (c) 0 gráfico que mostra a curva de otimização das configurações dos valores de $R$ e $S$ em relação à área do quadrilátero. Em destaque, o ponto máximo da curva indicado pelo seu par ordenado e valor de área $((15,15) ; 225)$.

Visando maximizar o uso dos de todos os pares possíveis de serem determinados, esta sistemática comentada anteriormente foi desenvolvida duas vezes. Ou seja, cada voluntário observou 30 pares de conjunto de fotografias experimentais o invés de 15 (sendo que 4/30 foram pares de conjuntos efetivos e 26/30, não-pares de conjuntos efetivos). Além disso, os 
voluntários avaliaram pares originados de diversas combinações de catálogos, não apenas de uma só.

\subsubsection{Observação do catálogo de fotografias dos cães fotografados nas ruas}

Além das fotografias obtidas no CCZ, os conjuntos de fotos obtidos a campo também foram apresentados aos voluntários. No estudo a campo, os três dias de amostragem resultaram em 150 encontros, sendo que 137 foram fotografados. Nos 13 restantes, o animal não foi fotografado por razões como, por exemplo, fuga ou entrada em residência. As fotografias obtidas geraram um total de 600 de conjuntos de fotos (sendo 504 referentes ao $A, 57$ ao $B, 37$ ao $C$ e 2 ao D). Esses registros foram obtidos em 6 períodos (três manhãs e três tardes). Apesar de alguns animais não terem sido fotografados, para todos os cálculos realizados nesse trabalho foi considerado apenas os animais fotografados.

Neste caso, pares de conjunto de fotos que corresponderam a um mesmo encontro (ou seja, são conjuntos de um mesmo animal) foram utilizados, sob a finalidade de se avaliar a $P_{(\text {parlpar efetivo })}$. O fundamento desta idéia foi considerá-los como padrão ouro de campo.

Optou-se pela avaliação de quatro pares, pois devido ao fato de a maioria dos conjuntos obtidos serem de categoria $A$, a disparidade que poderia ocorrer ao se apresentar muitos pares de combinação A x A poderia ser muito grande se comparada com a proporção de combinações de outros 
catálogos apresentada entre as fotografias obtidas no CCZ. Assim, ao se observar a quantidade estimada de combinações de catálogos que cada voluntário observaria (considerando aqueles provenientes dos cães do CCZ), haveria uma desproporção de combinações de catálogo A x A em relação aos demais.

\subsubsection{Disponibilização do questionário e convite aos voluntários para participar do experimento}

Determinada a metodologia e a sistemática de avaliação da probabilidade de identificação dos pares de conjuntos de fotografias, 103 voluntários participaram do experimento, observando e indicando se os pares de conjuntos de fotos (seja os do CCZ ou do campo) apresentados correspondiam ou não ao mesmo animal. Não houve limite de tempo para os voluntários concluírem o teste.

Tendo em vista a possibilidade de se obter um número maior de voluntários e pela maior comodidade e conforto, o experimento foi disponibilizado pela Internet. Assim, os voluntários puderam participar do experimento "on-line", no qual, ao acessarem a página onde o experimento se encontrou hospedado (http://logicamix.com/), tiveram que informar o login e a senha (ambos enviados previamente para o e-mail do voluntário) para ter acesso à avaliação. Uma vez os voluntários logados ao sistema e iniciado o experimento, o próprio programa executaria aleatoriamente a seqüência e a combinação dos conjuntos de pares e quais pares corretos e incorretos 
seriam apresentadas (com relação às fotografias obtidas no CCZ) (Figura 9 10). A única constante foi o fato de terem sido apresentados 04 pares efetivos e 26 não-pares, com relação às fotografias obtidas experimentalmente, além dos 4 pares de conjuntos de fotos de um mesmo encontro obtidos nas ruas de Ibiúna. Os voluntários foram convidados pelos meios de comunicação disponíveis: e-mail, telefonemas, websites de relacionamento pessoal e comunicação pessoal e interpessoal. 


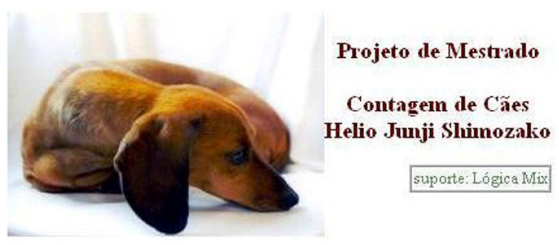

Fotos de Cães

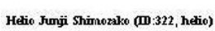

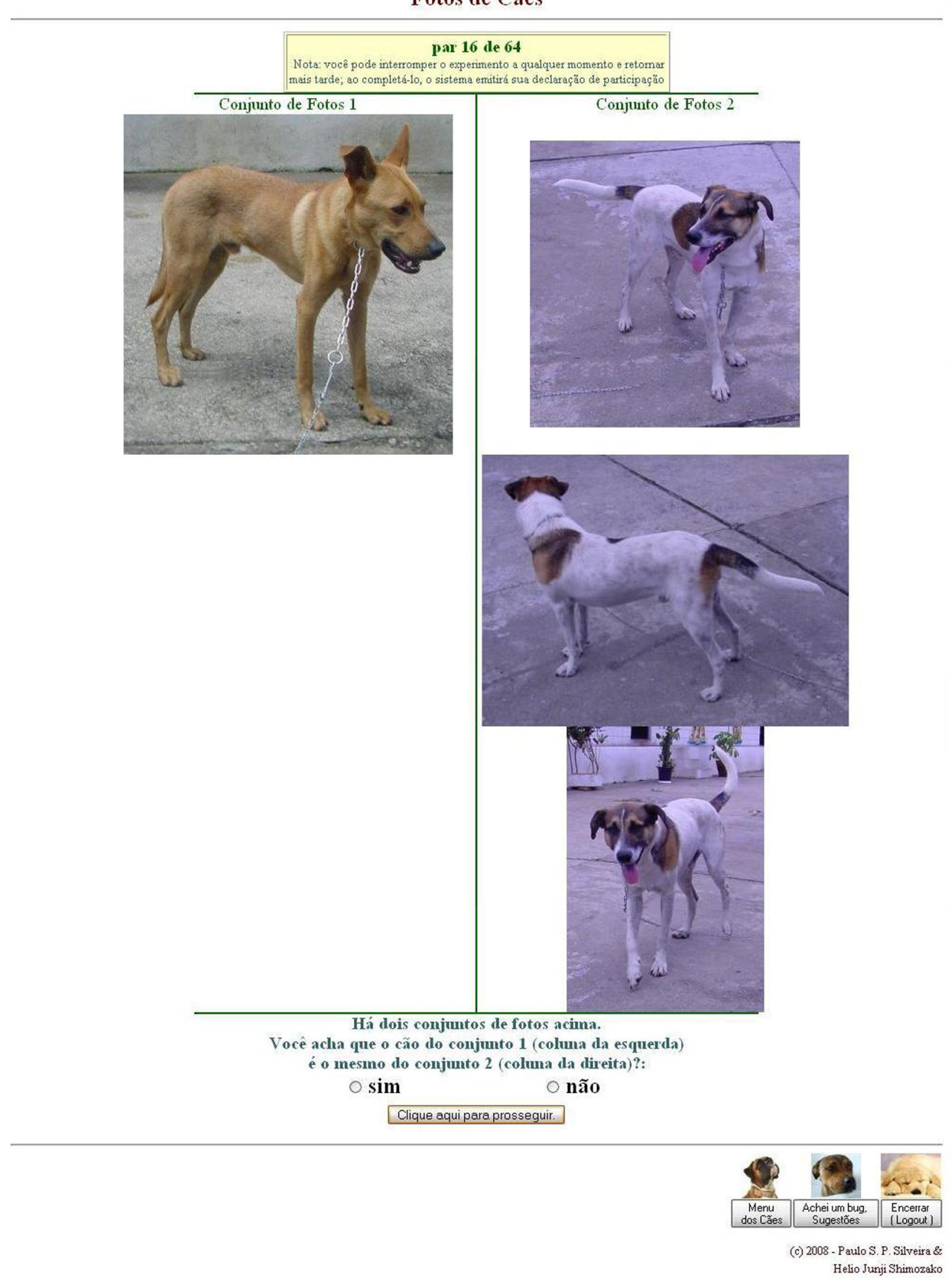

Figura 9: "Layout" do questionário "on line" utilizado neste trabalho. Nesse exemplo, foram apresentados dois conjuntos de fotos de cães internados no CCZ. 

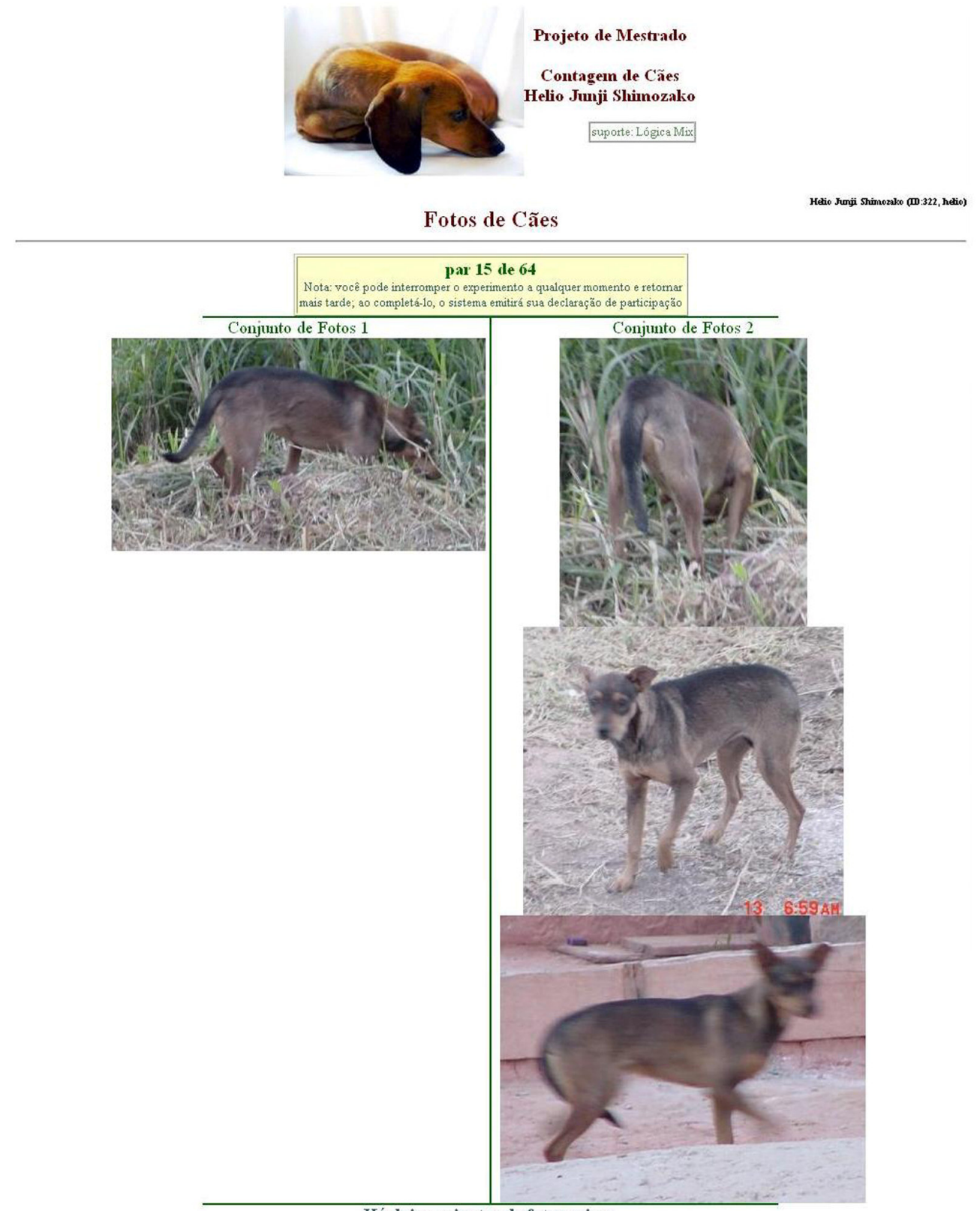

Há dois conjuntos de fotos acima.

Você acha que o cáo do conjunto 1 (coluna da esquerda)

é o mesmo do conjunto 2 (coluna da direita)?;

$O$ sim

กล̃o

Clique aqui para prosseguir.

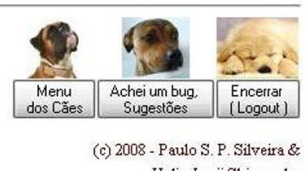

Figura 10: "Layout" do questionário "on line" utilizado neste trabalho. Nesse exemplo, foram apresentados dois conjuntos de fotos (de um mesmo encontro) obtidos no trabalho de campo. 


\subsubsection{Erros grosseiros e filtragem de voluntários}

Por definição, erros grosseiros são "enganos" que podem ocorrer na medição ou nos cálculos (Vuolo, 1996). Tecnicamente, resultados que contém erros dessa natureza não são passíveis de correção com nenhum tipo de tratamento estatístico. Segundo Vuolo (1996), quando existir qualquer suspeita de erro grosseiro, a medição do dado deve ser repetida ou, ainda, este deve ser excluído do banco de dados.

Sob o intuito de diminuir a influência dos erros desse porte, os resultados obtidos dos 103 voluntários foram submetidos a uma triagem, no qual foram comparados os seus resultados individualmente com o gabarito dos pares obtidos do CCZ e o dos 4 pares obtidos das ruas.

Foi adotado como critério (ponto de corte) o porcentual de acerto igual ou acima de $94,0 \%$ entre a soma dos 30 pares de conjuntos de fotos do CCZ e os 4 pares formados a partir de conjunto de fotos de um mesmo encontro. Este valor de $94 \%$ teve como hipótese a tolerância de $6 \%$ de erro dentro do pares de conjunto de fotos observados. Além disso, este ponto de corte otimiza a exclusão dos voluntários, ou seja, menos resultados são excluídos para se obter resultados igualmente satisfatórios. Assim, os voluntários que tiveram um resultado de acerto acima desse percentual dentre esses 34 pares, tiveram suas respostas consideradas na análise final.

Desta triagem, 12 dos 103 voluntários tiveram o percentual de acerto abaixo dos 94,0\% e tiveram seus resultados excluídos das análises. 


\subsection{Análise e interpretação dos dados obtidos a partir dos resultados do experimento on line}

\subsubsection{Observação das fotografias de cães do CCZ}

Os resultados obtidos da avaliação dos voluntários sobre as fotos obtidas no CCZ foram avaliados no geral, sendo que cada avaliação sobre um determinado par de conjuntos foi considerada um elemento amostral. Resultados de pares repetidos foram considerados individualmente (ou seja, repetições foram consideradas).

Tendo os resultados das avaliações de pares, pode-se construir o seguinte diagrama (Thrusfield, 2004) (Quadro 4):

Quadro 4: Diagrama gerado a partir dos resultados da avaliação dos voluntários para a observação de conjunto de pares e de não pares de conjunto de fotos do CCZ.

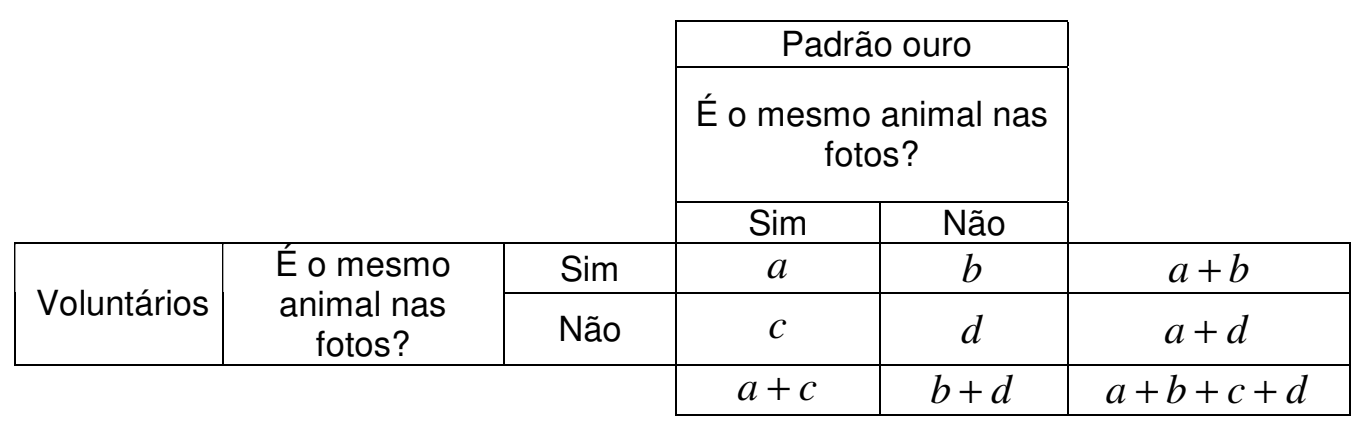


Pelos valores obtidos do quadro acima, foi possível obter a concordância observada (CO), $P_{(\text {parlpar efetivo })}, P_{(\text {não parlnão par efetivo })}, P_{(\text {parlpar para o voluntário })}$ e $P_{(\text {não parlnão par para o voluntário })}$ :

- Concordância observada: $C O=\frac{a+d}{a+b+c+d}$

- $P_{(\text {parlpar efetivo })}=\frac{a}{a+c}$

$-P_{(\text {não parlnão par efetivo })}=\frac{d}{b+d}$

- $P_{(\text {parlpar para o voluntário })}=\frac{a}{a+b}$

- $P_{(\text {não parinão par para o voluntário })}=\frac{d}{c+d}$

A concordância observada, entretanto, não considera a concordância causada pelo efeito da aleatoriedade (Thrusfield, 2004). Uma comparação mais rigorosa, chamada de teste Kappa, leva em conta a ocorrência da concordância casual.

Para a determinação da concordância esperada (CE) (ou seja, a concordância casual) e do índice Kappa, foi gerado o quadro de resultados esperados a partir dos valores marginais do quadro dos resultados observados (Quadro 5): 
Quadro 5: Diagrama de resultados esperados gerado a partir dos resultados marginais da avaliação dos voluntários para a observação de conjunto de pares e de não pares de conjunto de fotos do CCZ.

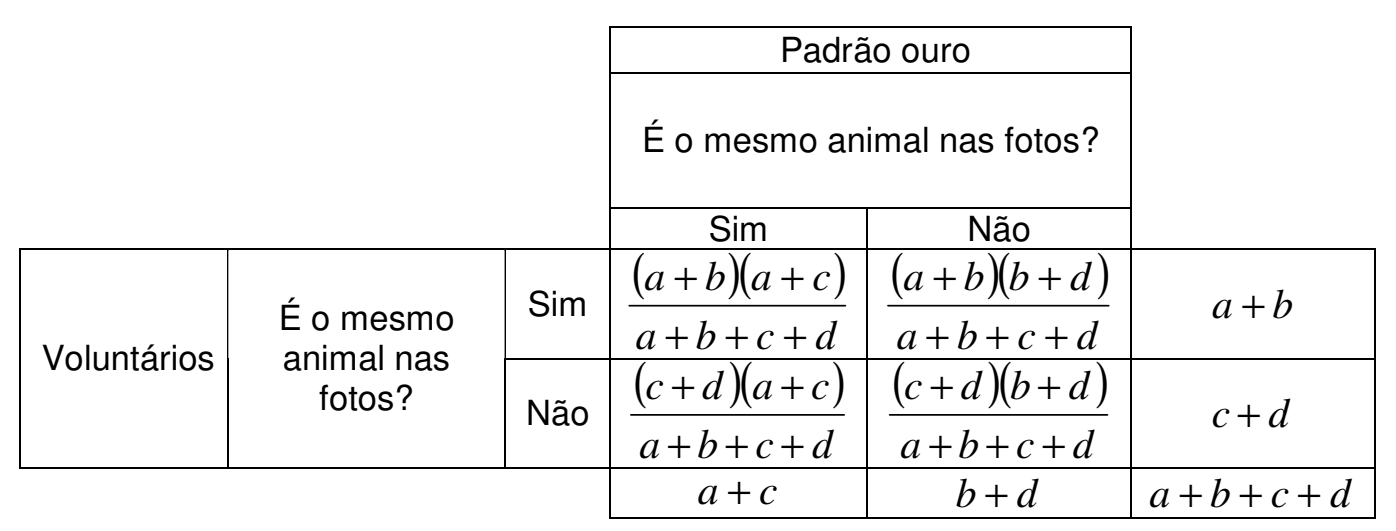

A concordância esperada foi então calculada:

- Concordância esperada:

$$
C E=\frac{\left[\frac{(a+b)(a+c)}{(a+b+c+d)}\right]+\left[\frac{(b+d)(c+d)}{(a+b+c+d)}\right]}{(a+b+c+d)}
$$

Para a obtenção do índice Kappa, calculou-se (Thrusfield, 2004):

I) A diferença: $C O-C E$;

II) O máximo possível de concordância além da casualidade: $1-C E$

III) O índice Kappa, que representa o excesso de concordância acima da casualidade, dividida pelo potencial de excesso: Kappa $=\frac{(C O-C E)}{(1-C E)}$. Ou seja, 
obteve-se a probabilidade de os resultados terem ocorrido devido às evidências.

O recurso requerido para esta análise foi o software Microsoft@ Office Excell 2003.

\subsubsection{Avaliação da probabilidade de identificação utilizando fotografias obtidas nas ruas}

A partir das fotografias obtidas de cada encontro durante os seis períodos de amostragem, foram avaliadas as probabilidades de identificação desses cães de forma semelhante ao que foi determinado para as fotografias dos cães do CCZ. Ou seja, dado que em alguns encontros foram obtidas mais que uma foto, cada um desses encontros representou o padrão ouro do trabalho de campo (isto é, quando um par de conjuntos de fotos originadas de um mesmo encontro foram colocadas sob avaliação pelos voluntários).

Sob esse propósito, dos 34 pares de conjuntos apresentados aos voluntários, 4 deles foram relacionados respectivamente a 4 encontros escolhidos aleatoriamente (desde que apresentasse pelo menos dois conjunto de fotos disponíveis). A partir dos resultados obtidos dessas observações, pode-se determinar $P_{(\text {parlpar efetivo })}$ considerando as fotos obtidas a campo.

Os recursos requeridos para esta análise foi o software Microsoft ${ }^{\circledR}$ Office Excell 2003. 


\subsection{Estimativa da população do bairro de Santa Lúcia seguindo o método clássico: estimador de Pettersen, estimador de Chapman e Método de Beck}

Para a estimativa da população canina, todos os valores obtidos em forma decimal foram convertidos para números naturais (arredondamento para cima).

Por hipótese, foi assumido que não há diferenças significativas entre 0 grau de observação do pesquisador em relação aos voluntários.

\subsubsection{Considerando cada período como amostras independentes: ótica do pesquisador}

Considerando os seis períodos amostrados como independentes, as 15 combinações de períodos determinados dois a dois tiveram seus encontros comparados entre si e o número de pares (ou seja, aqueles que demonstraram animais presentes nos dois períodos confrontados, sob a ótica do pesquisador) foi determinado para cada combinação.

Dada as quantidades de pares assinalados pelo pesquisador, o total de pares de encontros possíveis de serem determinados em função dos dois períodos analisados, além de da $P_{(\text {parlpar para o voluntario) }}$ e $P_{\text {(não parlnão par para o voluntário) }}$ obtidos a partir dos resultados das observações dos cães do CCZ, e tendo por hipótese que não há diferenças significativas (em termos de modelo) 
entre os cães do CCZ e os do bairro de Santa Lúcia, os pares estipulados pelo pesquisador podem ser ajustados (Quadro 6).

Quadro 6: Diagrama representando a relação entre a estimativa de pares e de não pares assinalados pelo pesquisador e seus valores corrigidos.

\begin{tabular}{|c|c|c|c|c|c|}
\hline & \multirow{2}{*}{\multicolumn{2}{|c|}{$\begin{array}{c}\text { Padrão ouro } \\
\text { (em relação às ruas) } \\
\text { É o mesmo animal nas fotos? }\end{array}$}} & \\
\hline & & & & & \\
\hline & & & Sim & Não & \\
\hline \multirow{2}{*}{ Pesquisador } & \multirow{2}{*}{$\begin{array}{c}\text { É o mesmo } \\
\text { animal nas } \\
\text { fotos? }\end{array}$} & Sim & $a$ & $b$ & $a+b(=P)$ \\
\hline & & Não & $c$ & $d$ & $a+d(=N P)$ \\
\hline & & & $a+c\left(=P_{\text {ajustado }}\right)$ & $b+d$ & $a+b+c+d(=U)$ \\
\hline
\end{tabular}

Dado que:

- $\mathrm{P}=$ Pares marcados pelo pesquisador;

- $\quad \mathrm{NP}=$ Não-pares marcados pelo pesquisador;

- $U=$ Total de pares de encontros possíveis de serem determinados em função dos dois períodos analisados (este valor é obtido pela multiplicação entre o total de encontros obtidos por cada uma das duas amostras analisadas);

foi possível estipular o ajuste dos pares assinalados pelo pesquisador da seguinte forma (baseado no Quadro 6 acima):

$$
a+c=P_{\text {corrigido }}
$$


Partindo da hipótese de similaridade no grau de observação do pesquisador em relação aos voluntários, tomando o Quadro 6 como referência, pela definição dada neste trabalho, obteve-se que:

$$
\begin{gathered}
c=N P-d \\
\frac{d}{N P}=P_{(\text {não parlnão par para o voluntário })} \Rightarrow d=N P . P_{(\text {não parlnão par para o voluntário })} \\
\frac{a}{P}=P_{(\text {par| par para o voluntário })} \Rightarrow a=P . P_{(\text {par| par para o voluntário })}
\end{gathered}
$$

Tomando como base as igualdades obtidas acima (equações 12 e 13), pelo Quadro 6 obteve-se:

$$
\begin{aligned}
c=N P-d & \Rightarrow c=N P-N P \cdot P_{(\text {não parrnão par para o voluntário })} \Rightarrow \\
c & =N P .\left\lfloor 1-P_{(\text {não parlnão par para o voluntário })}\right\rfloor
\end{aligned}
$$

Contudo, sabendo-se que $N P=U-P$, substituindo em (15):

$c=N P \cdot\left[1-P_{(\text {não parinão par para o voluntário })}\right\rfloor \Rightarrow c=(U-P) \cdot\left[1-P_{(\text {não parnão par para o voluntário })}\right\rfloor$

Por fim, substituindo os valores de a e c obtidos de (14) e (16) em (11):

$$
P_{\text {corrigido }}=P . P_{(\text {parl par para o voluntário })}+(U-P) \cdot\left[1-P_{(\text {não parlnão par para o voluntário })}\right\rfloor
$$


Tendo os valores de $P_{\text {ajustado }}$ para cada uma das combinações, além dos valores de encontros dos seis períodos, foi possível estimar o $\mathrm{N}$ da população de cães de Santa Lúcia considerando cada uma das 15 combinações, obtendo-se assim 15 estimativas possíveis e seus respectivos valores de variância e de desvio padrão. As estimativas, neste caso, foram determinadas pelos estimadores de Pettersen e de Chapman. Para esta estimativa, foram adotadas as premissas comentadas anteriormente (item 3.6 da revisão de literatura) (White et al., 1982; WHO; WSPA, 1990; Amstrup et al., 2005).

A população canina também foi estimada considerando o método de Beck (WHO; WSPA, 1990). Neste caso, as seis amostras foram consideradas simultaneamente. A partir da observação das fotografias de cada encontro obtidas em cada período, foi construído um histórico de encontro, onde o número de linhas corresponde ao número efetivo de animais diferentes observados nos três dias de amostragem e o número de colunas, o respectivo dia visitado. A representação do encontro ou nãoencontro com um determinado animal nos dias visitados foi caracterizada por 0 (zero) e 1 (um), sendo o 0 a indicação de não-encontro e 1, de encontro (White et al., 1982; Amstrup et al., 2005) (Tabela 3): 
Tabela 3: Exemplo de configuração de histórico de buscas para 3 momentos de amostragem. No exemplo, foram identificados 8 animais diferentes durante esse período. 1 representa o encontro com o animal no respectivo momento e 0 , o não-encontro.

\begin{tabular}{cccc}
\hline Animal & 1a. Amostra & 2a. Amostra & 3a. Amostra \\
\hline 01 & 1 & 1 & 1 \\
02 & 1 & 1 & 1 \\
03 & 1 & 1 & 0 \\
04 & 1 & 0 & 0 \\
05 & 0 & 1 & 1 \\
06 & 0 & 1 & 1 \\
07 & 0 & 1 & 0 \\
08 & 0 & 0 & 1 \\
\hline
\end{tabular}

A partir do histórico de encontro foi possível determinar os parâmetros necessários para a aplicação da fórmula do método de Beck para a estimação da população canina no bairro. Pelo histórico de encontro, podese determinar quantos animais novos e "repetidos" foram encontrados em cada amostragem. Tomando por hipótese os pressupostos descritos anteriormente para este trabalho, ao passo que amostras são levantadas nessa população, haveria um momento em que as animais encontrados seriam todos repetidos. Para representar este modelo por taxa de captura foram necessários parâmetros cumulativos a cada amostra e puderam ser obtidos pela observação do histórico de encontro. Este modelo foi elaborado considerando a situação com e sem o ajuste do número de animais que estiveram presentes em amostras anteriores.

Neste modelo, foi apresentada a reta ajustada para o comportamento dos pontos obtidos e o respectivo valor de $\mathrm{R}^{2}$.

A fim de se analisar diferenças estatísticas entre o tamanho da população no período da manhã e o da tarde, foram tomadas como base as seis estimativas relacionadas às três combinações envolvendo somente o 
período das manhãs e às três das tardes, tanto com relação aos estimadores de Pettersen quanto o de Chapman, (tanto nas situações com e sem ajuste do valor do número de pares de encontros coincidentes entre as amostras). Assim, tomando 4 amostras de $n=3$, foi aplicado o teste para variâncias iguais (teste $F$ ) e a prova $U$ de Mann Whithney (Massad et al., 2004). As comparações foram feitas duas a duas, considerando os $\mathrm{N}$ obtidos para as manhãs e tardes para os estimadores de Petersen e de Chapman. Foi utilizado o software MINITAB® Release 14.1 para a realização destes testes.

\subsubsection{Considerando cada dia como amostras independentes: ótica do pesquisador}

O primeiro passo do processo de identificação foi agrupar todos os encontros correspondentes aos mesmos animais (sob a ótica do pesquisador) amostrados em um mesmo dia (unificação dos encontros do período da manhã e da tarde). Essa etapa foi possível por meio da observação das fotografias obtidas em cada encontro e por meio das respectivas informações adquiridas a partir dos formulários utilizados.

Considerando a comparação dessas amostras duas a duas, teríamos 3 estimativas de $\mathrm{N}$ baseadas em amostragens por dia. Para cada combinação foi tomado o mesmo procedimento que o executado para a amostragem por período (tanto para o cálculo da estimativa da população de cães quanto para a correção do número de pares de encontros assinalados). 
Novamente, as estimativas foram baseadas nos estimadores de Pettersen e de Chapman (White et al., 1982; Amstrup et al., 2005).

A população canina também foi estimada considerando o método de Beck (WHO; WSPA, 1990), assim como na análise para os seis períodos descrita anteriormente. Neste caso, as três amostras foram consideradas simultaneamente. A partir da observação das fotografias de cada encontro obtidas em cada dia, foi construído o respectivo histórico de encontro desta configuração.

A partir do histórico de buscas foi possível determinar os parâmetros necessários para a aplicação da fórmula do método de Beck para a estimação da população canina no bairro. Assim, como descrito para a análise das amostras por período, foi descrito o modelo por taxa de captura para esta situação. Neste modelo, foi apresentada a reta ajustada para o comportamento dos pontos obtidos e o respectivo valor de $\mathrm{R}^{2}$. Além disso, foram consideradas as situações com e sem o ajuste do número de animais que estiveram presentes em duas amostras concomitantemente. 


\section{RESULTADOS}

\subsection{Resultados do experimento "on line"}

Foram convidadas a participar do experimento 262 pessoas, sendo que 103 responderam ao questionário.

A fim de amenizar o efeito causado por erros grosseiros, foi necessário antes de qualquer análise filtrar os resultados, eliminando aqueles cujos voluntários apresentaram uma quantidade de erros em relação ao padrão ouro igual ou acima do ponto de corte estipulado (maior ou igual à $94,0 \%$ de acerto). Seguindo esse critério, 12 voluntários tiveram seus resultados descontados do banco de dados geral.

Por opção de critério, os voluntários que responderam parcialmente ao questionário (4 pessoas) também foram excluídos.

\subsubsection{Observação das fotografias de cães do CCZ}

Considerando antes da eliminação de alguns voluntários, no total, foram observados 3104 pares de conjunto de fotografias de cães do CCZ. Destes, 486 foram considerados como o mesmo cão pelos voluntários, enquanto que 2618 foram considerados cães diferentes. Pelo padrão ouro, sabe-se que dos 3104 pares apresentados, 415 foram efetivamente 0 mesmo animal e 2689, efetivamente animais diferentes. 
Após a exclusão, no total, foram considerados 2730 pares de conjunto de fotografias de cães do CCZ. Destes, 378 foram considerados como 0 mesmo cão pelos voluntários, enquanto que 2352 foram considerados cães diferentes. Pelo padrão ouro, sabe-se que dos 2730 pares apresentados, 364 foram efetivamente o mesmo animal e 2366, efetivamente animais diferentes.

Fazendo um comparativo do antes e após a exclusão, os valores das probabilidades $\quad P_{(\text {parl par efetivo })}, \quad P_{(\text {não parlnão par efetivo })}, \quad P_{(\text {par| par parao voluntário })} \quad \mathrm{e}$ $P_{(\text {não parinão par para ovoluntário })}$ foram estimadas, além do cálculo do índice de concordância Kappa ${ }_{c c z}$ para a situação geral. A Tabela 4, 5 e 6 apresenta resumidamente estes resultados.

Tabela 4: Diagrama dos resultados gerais da avaliação dos pares de conjunto de fotos dos cães do CCZ pelos voluntários. Diagramas de resultados observados e esperados representando os resultados antes da exclusão de 12 voluntários.

Observados

\begin{tabular}{ccccc}
\cline { 3 - 4 } & & \multicolumn{2}{c}{ Padrão ouro } & \\
\cline { 3 - 5 } & & Pares & $\begin{array}{c}\text { Não- } \\
\text { Pares }\end{array}$ & Totais \\
\hline \multirow{2}{*}{ Voluntário } & Pares & 407 & 79 & 486 \\
& Não- & 8 & 2610 & 2618 \\
& Pares & 2689 & 3104 \\
\hline & Totais & 415 & 2689 \\
\hline
\end{tabular}

Esperados

\begin{tabular}{|c|c|c|c|c|}
\hline \multirow[t]{2}{*}{ (5) } & & \multicolumn{3}{|c|}{ Padrão ouro } \\
\hline & & Pares & $\begin{array}{l}\text { Não- } \\
\text { Pares }\end{array}$ & Totais \\
\hline \multirow{3}{*}{ Voluntário } & Pares & 65,0 & 421,0 & 486 \\
\hline & $\begin{array}{l}\text { Não- } \\
\text { Pares }\end{array}$ & 350,0 & 2268,0 & 2618 \\
\hline & Totais & 415 & 2689 & 3104 \\
\hline
\end{tabular}


Tabela 5: Diagrama dos resultados gerais da avaliação dos pares de conjunto de fotos dos cães do CCZ pelos voluntários. Diagramas de resultados observados e esperados representando os resultados após a exclusão de 12 voluntários.

Observados

\begin{tabular}{ccccc}
\cline { 3 - 4 } & & \multicolumn{2}{c}{ Padrão ouro } \\
\cline { 3 - 5 } & & Pares & $\begin{array}{c}\text { Não- } \\
\text { Pares }\end{array}$ & Totais \\
\hline \multirow{2}{*}{ Voluntário } & Pares & 359 & 19 & 378 \\
& Não- & 5 & 2347 & 2352 \\
\hline & Pares & & & \\
\hline & Totais & 364 & 2366 & 2730 \\
\hline
\end{tabular}

Esperados

\begin{tabular}{ccccc}
\cline { 3 - 4 } & & \multicolumn{2}{c}{ Padrão ouro } & \\
\cline { 3 - 4 } & & Pares & $\begin{array}{c}\text { Não- } \\
\text { Pares }\end{array}$ & Totais \\
\hline \multirow{2}{*}{ Voluntário } & Pares & 50,4 & 327,6 & 378 \\
& $\begin{array}{c}\text { Não- } \\
\text { Pares }\end{array}$ & 313,6 & 2038,4 & 2352 \\
\hline & Totais & 364 & 2366 & 2730 \\
\hline
\end{tabular}

Tabela 6: Diagrama dos resultados gerais da avaliação dos pares de conjunto de fotos dos cães do CCZ pelos voluntários. Valores dos parâmetros calculados a partir das duas situações - antes e após exclusão de 12 voluntários (Tabelas 4 e 5).

\begin{tabular}{ccc}
\cline { 2 - 3 } & Antes & Após \\
\hline$P_{(\text {parlpar efetivo })}$ & 0,981 & 0,986 \\
$P_{(\text {não par|não par efetivo })}$ & 0,971 & 0,992 \\
$P_{(\text {par|par para o voluntário })}$ & 0,837 & 0,950 \\
$P_{(\text {não par|não par para o voluntário })}$ & 0,997 & 0,998 \\
CO & 0,972 & 0,991 \\
CE & 0,752 & 0,765 \\
Kappa ${ }_{c c z}$ & 0,887 & 0,963 \\
\hline
\end{tabular}

\subsubsection{Observação das fotografias de cães obtidas nas ruas}

680 fotografias foram obtidas durante os três dias de amostragem no bairro de Santa Lúcia, que constituíram 600 conjuntos de fotos (somando todos os de padrão A, B, C ou D), durante os 137 encontros fotografados nos 3 dias de buscas. Em média, cada encontro gerou 4,4 conjuntos de fotos. 
A fim de avaliar o uso de fotografias obtidas de um mesmo encontro como padrão ouro de campo, pares de conjuntos de fotografias de um mesmo encontro também foram submetidos à observação dos voluntários.

O resultado obtido antes da exclusão dos 12 voluntários considerou que 217 dos 228 pares de conjunto de fotos apresentados aos voluntários foram considerados pares efetivos. Assim, a $P_{(\text {parlpar efetivo })}$ neste caso foi calculado em 0,952.

Considerando apenas o cálculo após a exclusão dos 12 voluntários, foram apresentados 207 pares de conjunto de fotos correspondentes a um mesmo encontro, sendo que 198 foram considerados pares efetivos pelos voluntários. Logo, o valor de $P_{(\text {parlpar efetivo })}$ para as fotografias de campo, no geral, foi de 0,957 . Pouca alteração de resultado ocorreu em relação ao resultado antes da exclusão de voluntários. Este resultado foi próximo àquele obtido para o conjunto de fotos do CCZ (considerando a situação após a exclusão dos 12 voluntários, ou seja, $\left.P_{(\text {parlpar efetivo })}{ }_{C C Z}=0,986\right)$.

\subsection{Estimação da população canina livre nas ruas do bairro de Santa Lúcia}

\subsubsection{Considerando cada período como amostras individuais: ótica do pesquisador}

Considerando apenas a ótica do pesquisador, foram determinadas as estimativas populacionais considerando os seis períodos pareados dois a 
dois. Para fins de praticidade, em alguns momentos, os períodos foram identificados pela codificação representada no Quadro 7.

Quadro 7: Codificação e identificação dos períodos amostrados.

\begin{tabular}{|c|c|c|c|}
\hline & 30/5/2006 & 6/6/2006 & 13/6/2006 \\
\hline Manhã & 1 & 3 & 5 \\
\hline Tarde & 2 & 4 & 6 \\
\hline
\end{tabular}

A Tabela 7 representa o histórico de encontro considerando os seis períodos amostrados. 
Tabela 7: Número de cães que apresentaram determinado histórico de encontro durante os seis períodos de amostragem. $O$ número 1 no histórico representa que 0 animal foi encontrado e fotografado no período, enquanto que o número 0 significa que o animal não foi encontrado.

\begin{tabular}{|c|c|c|c|c|c|c|}
\hline \multirow[b]{2}{*}{$\begin{array}{l}\text { Número de indivíduos que } \\
\text { receberam o respectivo } \\
\text { histórico }\end{array}$} & \multicolumn{2}{|c|}{$30 / 5 / 2006$} & \multicolumn{2}{|c|}{$6 / 6 / 2006$} & \multicolumn{2}{|c|}{$13 / 6 / 2006$} \\
\hline & Manhã & Tarde & Manhã & Tarde & Manhã & Tarde \\
\hline 1 & 1 & 1 & 1 & 1 & 0 & 1 \\
\hline 1 & 1 & 1 & 0 & 1 & 1 & 1 \\
\hline 1 & 1 & 1 & 0 & 1 & 0 & 1 \\
\hline 1 & 1 & 1 & 0 & 0 & 0 & 0 \\
\hline 1 & 1 & 1 & 0 & 0 & 0 & 1 \\
\hline 1 & 1 & 0 & 1 & 0 & 0 & 1 \\
\hline 1 & 1 & 0 & 1 & 1 & 0 & 0 \\
\hline 1 & 1 & 0 & 1 & 0 & 1 & 1 \\
\hline 1 & 1 & 0 & 1 & 0 & 1 & 0 \\
\hline 1 & 1 & 0 & 1 & 1 & 1 & 0 \\
\hline 1 & 1 & 0 & 0 & 0 & 1 & 1 \\
\hline 1 & 1 & 0 & 0 & 1 & 0 & 1 \\
\hline 1 & 1 & 0 & 0 & 0 & 0 & 1 \\
\hline 7 & 1 & 0 & 0 & 0 & 0 & 0 \\
\hline 1 & 0 & 1 & 1 & 1 & 0 & 1 \\
\hline 1 & 0 & 1 & 1 & 1 & 0 & 0 \\
\hline 1 & 0 & 1 & 1 & 0 & 0 & 0 \\
\hline 1 & 0 & 1 & 1 & 1 & 1 & 1 \\
\hline 1 & 0 & 1 & 1 & 1 & 1 & 0 \\
\hline 1 & 0 & 1 & 0 & 1 & 0 & 0 \\
\hline 1 & 0 & 1 & 0 & 0 & 1 & 0 \\
\hline 1 & 0 & 1 & 0 & 0 & 0 & 1 \\
\hline 2 & 0 & 1 & 0 & 1 & 1 & 1 \\
\hline 2 & 0 & 1 & 0 & 1 & 1 & 0 \\
\hline 9 & 0 & 1 & 0 & 0 & 0 & 0 \\
\hline 1 & 0 & 0 & 1 & 1 & 0 & 1 \\
\hline 1 & 0 & 0 & 1 & 1 & 1 & 1 \\
\hline 1 & 0 & 0 & 1 & 0 & 1 & 1 \\
\hline 1 & 0 & 0 & 1 & 0 & 1 & 0 \\
\hline 1 & 0 & 0 & 1 & 0 & 0 & 1 \\
\hline 6 & 0 & 0 & 1 & 0 & 0 & 0 \\
\hline 3 & 0 & 0 & 0 & 1 & 0 & 0 \\
\hline 4 & 0 & 0 & 0 & 0 & 1 & 1 \\
\hline 3 & 0 & 0 & 0 & 0 & 1 & 0 \\
\hline 5 & 0 & 0 & 0 & 0 & 0 & 1 \\
\hline
\end{tabular}

Para cada número de pares encontrado pelo pesquisador em cada combinação de período foi feito o respectivo ajuste utilizando a equação (17) 
com base nas $P_{(\text {parlpar para o voluntário })}$ e $P_{(\text {não parlnão par para ovoluntário })}$. A partir desses valores de pares ajustado, as populações foram estimadas com base nos estimadores de Pettersen e de Chapman e tiveram seus respectivos valores de variância calculados. A Tabela 8 apresenta os resultados das populações estimadas diante de cada combinação de períodos.

Tabela 8: Estimativa da população para cada uma das 15 combinações de períodos, considerando a ótica do pesquisador. Np representa a estimativa obtida pelo estimador de Pettersen e Nc, pelo estimador de Chapman. $p=$ número animais coincidentes nos dois encontros confrontados, $S^{2}=$ variância, $S=$ desvio padrão, $S m=$ desvio padrão da média.

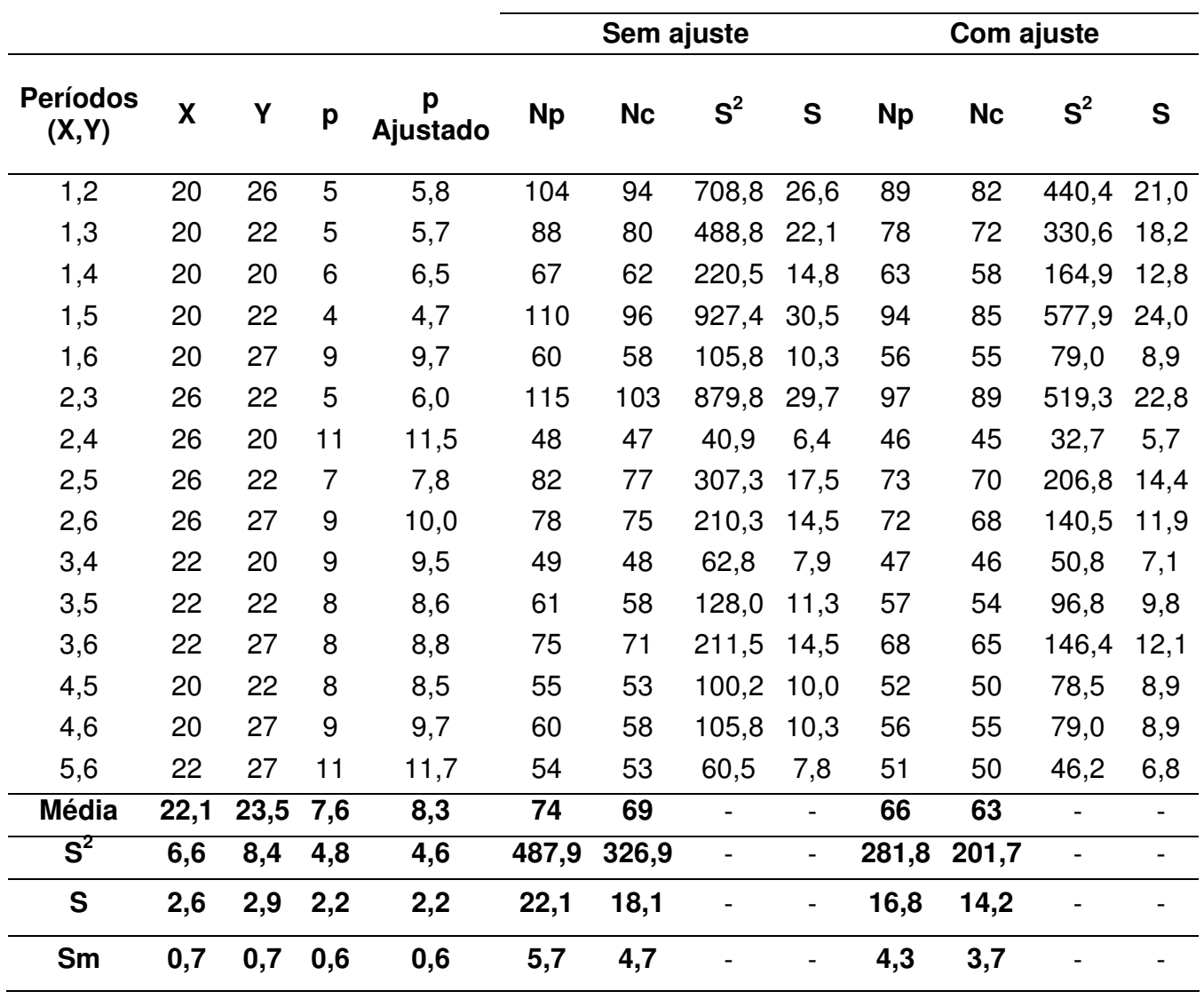

Considerando as seis amostras simultaneamente, o método de Beck foi utilizado para a estimação da população nessa configuração (Tabela 9). Os valores de $\mathrm{m}$ e $\mathrm{n}$ fora corrigidos utilizando o mesmo princípio aplicado 
para a correção do número de pares nos estimadores de Petersen e Chapman.

Tabela 9: Estimativa da população de cães livres nas vias públicas com base no estimador descrito pelo Método de Beck (WHO; WSPA, 1990). Assim como nas estimações anteriores, foi realizado o reajusto de $\mathrm{m}$ e $\mathrm{n}$ em função do pareamento dos encontros. Em (a) estimação sem ajuste e (b) com ajuste.

(a)

\begin{tabular}{cccccccc}
\cline { 2 - 8 } & \multicolumn{1}{c}{ Sem ajuste } \\
\hline Período & $\mathbf{M}$ & $\mathbf{m}$ & $\sum \mathbf{m}$ & $\mathbf{n}$ & $\mathbf{M n}$ & $\left.\sum \mathbf{M n}\right)$ & $\mathbf{N}$ \\
\hline $\mathbf{3 0 / 5 / 2 0 0 6}$ (Manhã) & 20 & 0 & 0 & 0 & 0 & 0 & - \\
$\mathbf{3 0 / 5 / 2 0 0 6}$ (Tarde) & 26 & 5 & 5 & 20 & 520 & 520 & 104,0 \\
$\mathbf{6 / 6 / 2 0 0 6}$ (Manhã) & 22 & 11 & 16 & 41 & 902 & 1422 & 88,9 \\
$\mathbf{6 / 6 / 2 0 0 6}$ (Tarde) & 20 & 17 & 33 & 52 & 1040 & 2462 & 74,6 \\
$\mathbf{1 3 / 6 / 2 0 0 6}$ (Manhã)) & 22 & 15 & 48 & 55 & 1210 & 3672 & 76,5 \\
$\mathbf{1 3 / 6 / 2 0 0 6}$ (Tarde) & 27 & 22 & 70 & 62 & 1674 & 5346 & $\mathbf{7 7}$ \\
\hline
\end{tabular}

(b)

\begin{tabular}{cccccccc}
\cline { 3 - 8 } & \multicolumn{6}{c}{ Com ajuste } \\
\hline Período & $\mathbf{M}$ & $\mathbf{m}$ & $\sum \mathbf{m}$ & $\mathbf{n}$ & $\mathbf{M n}$ & $\left.\sum \mathbf{M n}\right)$ & $\mathbf{N}$ \\
\hline $\mathbf{3 0 / 5 / 2 0 0 6}$ (Manhã) & 20 & 0,0 & 5,8 & 0,0 & 0,0 & 0,0 & - \\
$\mathbf{3 0 / 5 / 2 0 0 6}$ (Tarde) & 26 & 5,8 & 5,8 & 20,0 & 520,0 & 520,0 & 89,0 \\
$\mathbf{6 / 6 / 2 0 0 6}$ (Manhã) & 22 & 12,3 & 18,2 & 40,2 & 883,4 & 1403,4 & 77,2 \\
$\mathbf{6 / 6 / 2 0 0 6}$ (Tarde) & 20 & 18,3 & 36,5 & 49,0 & 980,0 & 2383,4 & 65,3 \\
$\mathbf{1 3 / 6 / 2 0 0 6}$ (Manhã) & 22 & 16,8 & 53,3 & 50,7 & 1115,0 & 3498,4 & 65,6 \\
$\mathbf{1 3 / 6 / 2 0 0 6}$ (Tarde) & 27 & 24,4 & 77,7 & 55,9 & 1509,1 & 5007,5 & $\mathbf{6 5}$ \\
\hline
\end{tabular}

Considerando o número de animais novos removidos por período e a soma do número de animais previamente removidos, a população total foi estimada pela taxa de captura, construindo um modelo linear (WHO; WSPA 1990). A Figura 11 e a Tabela 10 representam o significado deste modelo. As retas obtidas para este modelo, com e sem ajuste foram $y=-0,3567 x+$ $22,8540\left(R^{2}=0,8823\right)$ e $y=-0,2983 x+22,6009\left(R^{2}=0,8505\right)$, respectivamente. 


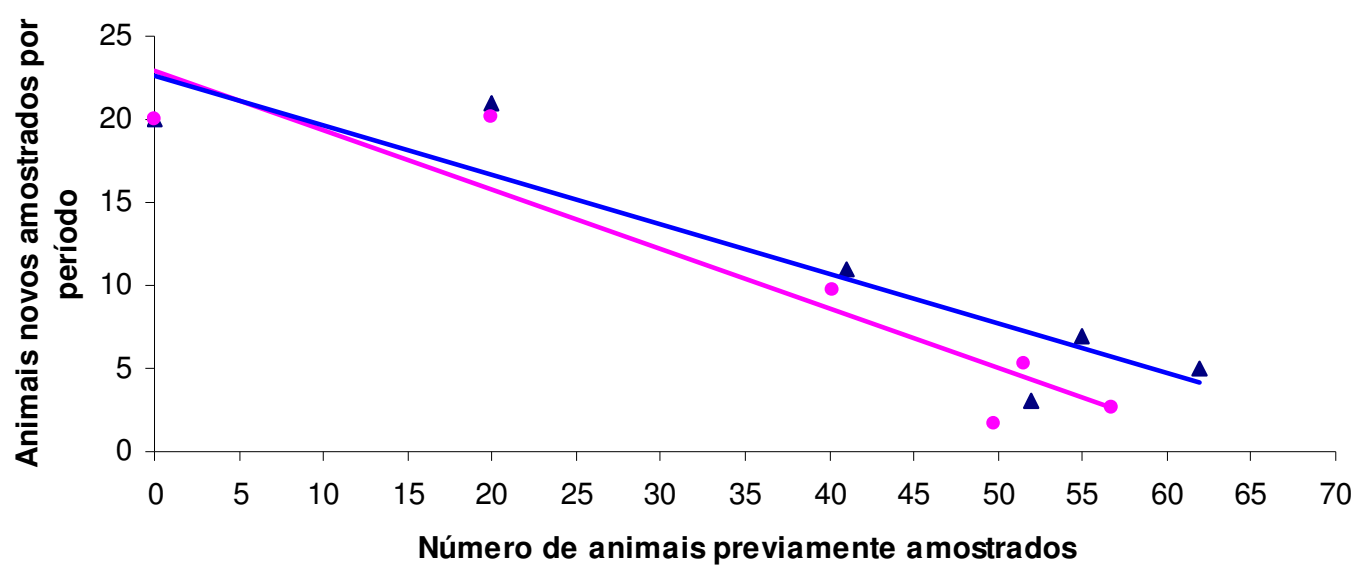

^ Sem ajuste - Com ajuste _L Linear (Com ajuste) _ Linear (Sem ajuste)

Figura 11: Representação do número de animais novos e os previamente capturados (com e sem ajuste) por período, além da referida linha de tendência para os seis pontos (períodos amostrados). Para os pontos sem ajuste, a equação da reta é representada por $y=-$ $0,2983 x+22,6009\left(R^{2}=0,8505\right)$ e para os com ajuste, $y=-0,3567 x+22,8540\left(R^{2}=\right.$ $0,8823)$. Substituindo a equação das retas teóricas por $y=0$, obtém-se o valor na abscissa aproximado de 75,8 (sem correção) e de 64,1 (com correção), que corresponde ao número total teórico de animais nesta população quando não houver mais animais novos a serem amostrados.

Tabela 10: Número de animais novos e previamente amostrados por período amostrado. 0 Dia $\mathrm{n}$ representa a estimativa da população caso todos os animais fossem removidos. Em (a) estimação sem ajuste e (b) com ajuste.

\begin{tabular}{cccccccc} 
(a) & \multicolumn{3}{c}{$\mathbf{3 0 / 5 / 2 0 0 6}$} & \multicolumn{2}{c}{$\mathbf{6 / 6 / 2 0 0 6}$} & \multicolumn{1}{c}{$\mathbf{1 3 / 6 / 2 0 0 6}$} & Período \\
& Manhã & Tarde & Manhã & Tarde & Manhã & Tarde & $\mathrm{n}$ \\
\hline $\begin{array}{c}\text { Previamente } \\
\text { amostrados }\end{array}$ & 0 & 20 & 41 & 52 & 55 & 62 & 76 \\
\hline $\begin{array}{c}\text { Animais } \\
\text { novos }\end{array}$ & 20 & 21 & 11 & 3 & 7 & 5 & 0 \\
amostrados & & & & & & & \\
\hline
\end{tabular}

\begin{tabular}{|c|c|c|c|c|c|c|c|}
\hline \multirow[t]{2}{*}{ (b) } & \multicolumn{2}{|c|}{$30 / 5 / 2006$} & \multicolumn{2}{|c|}{$6 / 6 / 2006$} & \multicolumn{2}{|c|}{$13 / 6 / 2006$} & \multirow{2}{*}{$\begin{array}{c}\text { Período } \\
\text { n }\end{array}$} \\
\hline & Manhã & Tarde & Manhã & Tarde & Manhã & Tarde & \\
\hline $\begin{array}{l}\text { Previamente } \\
\text { removidos }\end{array}$ & 0 & 20 & 40,2 & 49,8 & 51,5 & 56,7 & 65 \\
\hline $\begin{array}{c}\text { Animais } \\
\text { novos } \\
\text { removidos }\end{array}$ & 20 & 20,2 & 9,7 & 1,7 & 5,2 & 2,6 & 0 \\
\hline
\end{tabular}


Para a análise das diferenças entre o tamanho da população no período da manhã e o da tarde, foram tomadas como base as seis estimativas relacionadas às três combinações de manhãs e de tarde, tanto com relação aos estimadores de Pettersen quanto o de Chapman (com e sem ajustes do valor do número de animais coincidentes nas duas amostras). Utilizando o teste para variâncias iguais (teste $F$ ) e a prova $U$ de Mann Whithney (Massad et al., 2004), os resultados dos valores descritivos do teste encontram-se na Tabela 11:

Tabela 11: Valores de p para o teste para variâncias iguais (teste F) e a Prova U de Mann Whithney.

\begin{tabular}{cccc}
\cline { 3 - 4 } & & $\begin{array}{c}\text { Teste F } \\
\text { (Valor do } \\
\text { nível } \\
\text { descritivo) }\end{array}$ & $\begin{array}{c}\text { Prova U de } \\
\text { Mann Whithney } \\
\text { (Valor do nível } \\
\text { descritivo) }\end{array}$ \\
\hline \multirow{2}{*}{ Sem ajuste } & Petersen (Manhã x Tarde) & 0,558 & 0,190 \\
& Chapman (Manhã x Tarde) & 0,720 & 0,275 \\
\cline { 1 - 2 } Com ajuste & Petersen (Manhã x Tarde) & 0,629 & 0,190 \\
& Chapman (Manhã x Tarde) & 0,770 & 0,382 \\
\hline
\end{tabular}

Os valores do nível descritivo para o teste $\mathrm{F}$ não acusaram diferenças significativas nas variâncias das amostras de $\mathrm{N}$ do período da manhã e o da tarde. Além disso, pela a Prova U de Mann Whithney não houve diferenças significativas entre os valores de $\mathrm{N}$ obtidos entre as amostragens da manhã e as da tarde. 


\subsubsection{Considerando os dias como amostras individuais: ótica do pesquisador}

Para proceder à estimação em função das amostragens por dia, as amostras dos períodos correspondentes ao dia foram unificadas. Ou seja, por meio da observação das fotografias dos encontros obtidos em dois períodos de um mesmo dia, aqueles que corresponderam ao mesmo animal para o pesquisador foram considerados como um único encontro. A Tabela 12 apresenta o número de encontros efetivos por dia (animais distintos).

Tabela 12: Número de animais distintos encontrados por dia após a unificação dos dois períodos de amostragem realizadas em cada dia. Os períodos foram referidos conforme a codificação descrita no Quadro 7.

\begin{tabular}{ccccc}
\hline $\begin{array}{c}\text { Períodos } \\
(\mathbf{X}, \mathbf{Y})\end{array}$ & $\mathbf{X}$ & $\mathbf{Y}$ & $\mathbf{p}$ & Número de animais distintos encontrados por dia \\
\hline 1,2 & 20 & 26 & 5 & 41 \\
3,4 & 22 & 20 & 9 & 33 \\
5,6 & 22 & 27 & 11 & 38 \\
\hline
\end{tabular}

Entre os três dias de amostragem, foram observados 68 cães fotografados, sendo 41 considerados machos e 26, fêmeas. Em alguns casos, o sexo foi determinado pelo pareamento e dos encontros e respectivo registro anterior. Por exemplo, se em um primeiro momento o sexo de um certo cão não foi determinado, caso este fosse reencontrado e tivesse o sexo definido, logo, o animal seria caracterizado pela informação obtida pelo reencontro.

Durante os três dias de visitas (sob intervalos de sete dias entre si), obteve-se o seguinte histórico de encontro (Tabela 13): 
Tabela 13: Número de cães que apresentaram determinado histórico de encontro durante os três dias de amostragem. O número 1 no histórico representa que 0 animal foi encontrado e fotografado no dia, enquanto que o número 0 significa que 0 animal não foi encontrado.

\begin{tabular}{cccc}
\cline { 2 - 4 } & \multicolumn{3}{c}{ Histórico } \\
\hline $\begin{array}{c}\text { Número de indivíduos que receberam o } \\
\text { respectivo histórico }\end{array}$ & $\mathbf{3 0 / 0 5 / 2 0 0 6}$ & $\mathbf{0 6 / 0 6 / 2 0 0 6}$ & $\mathbf{1 3 / 0 6 / 2 0 0 6}$ \\
\hline 15 & 1 & 1 & 1 \\
4 & 1 & 1 & 0 \\
5 & 1 & 0 & 1 \\
5 & 0 & 1 & 1 \\
17 & 1 & 0 & 0 \\
9 & 0 & 1 & 0 \\
12 & 0 & 0 & 1 \\
\hline
\end{tabular}

A partir da Tabela 13, tendo informação de quantos animais estiveram presentes em dois dias escolhidos dois a dois entre os três, foi estimada a população de cães nas ruas com base nessas amostras utilizando os estimadores de Pettersen e de Chapman (Tabela 14). Ainda, considerando as três amostras simultaneamente, o método de Beck foi utilizado para a estimação da população nessa configuração (Tabela 15).

Tabela 14: Estimativa da população de cães livres nas vias públicas com base no estimador de Pettersen (Nc) e de Chapman (Nc) (White et al., 1982; Amstrup et al., 2005). Ao invés de se criar um outro código para representar os dias, preferiu-se utilizar a representação do código do par ordenado dos períodos para representar as amostras dos dias. $p=$ número animais coincidentes nos dois encontros confrontados, $S^{2}=$ variância, $S=$ desvio padrão, $\mathrm{Sm}=$ desvio padrão da média.

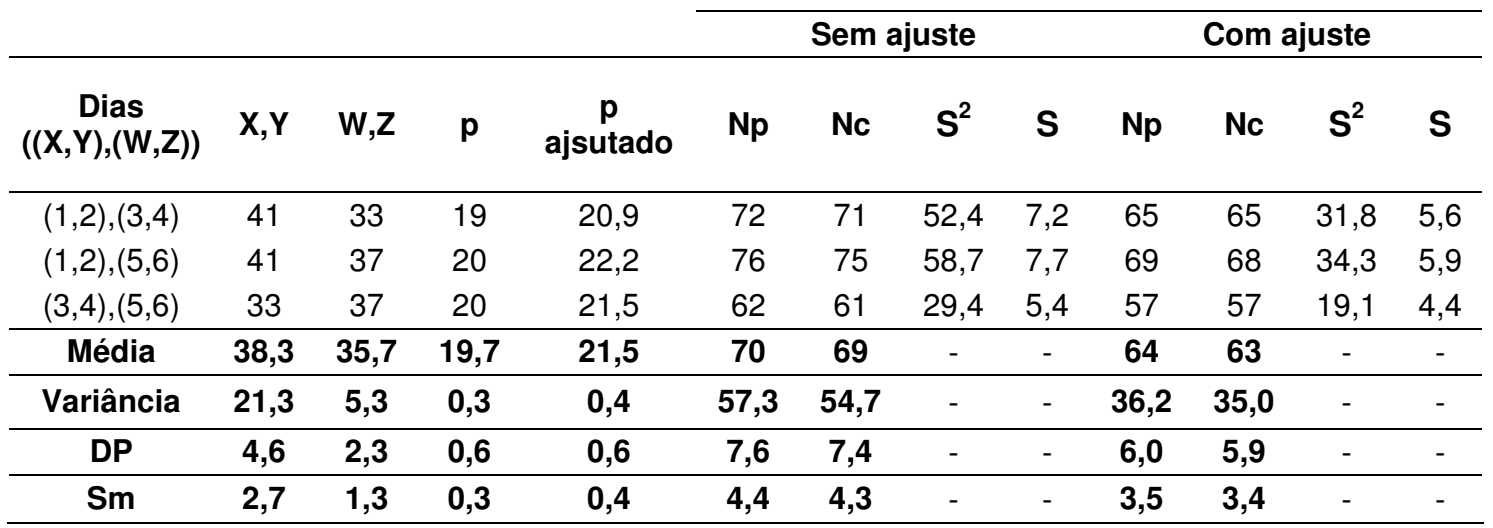


Tabela 15: Estimativa da população de cães livres nas vias públicas com base no estimador descrito pelo Método de Beck (WHO; WSPA, 1990). Assim como nas estimações anteriores, foi realizado o reajusto de $\mathrm{m}$ e $\mathrm{n}$ em função do pareamento dos encontros. Em (a) estimação sem ajuste e (b) com ajuste.

(a)

\begin{tabular}{cccccccc}
\cline { 3 - 8 } & \multicolumn{6}{c}{ Sem ajuste } \\
\hline Dia & $\mathbf{M}$ & $\mathbf{m}$ & $\sum \mathbf{m}$ & $\mathbf{n}$ & $\mathbf{M n}$ & $\sum(\mathbf{M n})$ & $\mathbf{N}$ \\
\hline $\mathbf{3 0 / 0 5 / 2 0 0 6}$ & 41 & 0 & 0 & 0 & 0 & 0 & - \\
$\mathbf{0 6 / 0 6 / 2 0 0 6}$ & 33 & 19 & 19 & 41 & 1353 & 1353 & 71,2 \\
$\mathbf{0 3 / 0 6 / 2 0 0 6}$ & 37 & 25 & 44 & 55 & 2035 & 3388 & $\mathbf{7 7}$ \\
\hline
\end{tabular}

(b)

\begin{tabular}{cccccccc}
\cline { 3 - 8 } & \multicolumn{7}{c}{ Com ajuste } \\
\hline Dia & $\mathbf{M}$ & $\mathbf{m}$ & $\sum \mathbf{m}$ & $\mathbf{n}$ & $\mathbf{M n}$ & $\sum(\mathbf{M n})$ & $\mathbf{N}$ \\
\hline $\mathbf{3 0 / 0 5 / 2 0 0 6}$ & 41 & 0,0 & 0,0 & 0,0 & 0,0 & 0,0 & \\
$\mathbf{0 6 / 0 6 / 2 0 0 6}$ & 33 & 20,9 & 20,9 & 41,0 & 1353,0 & 1353,0 & 64,8 \\
$\mathbf{0 3 / 0 6 / 2 0 0 6}$ & 37 & 28,0 & 48,9 & 53,1 & 1965,4 & 3318,4 & $\mathbf{6 8}$ \\
\hline
\end{tabular}

Ainda, tomando como referência o número de animais novos removidos por dia e a soma do número de animais previamente removidos, a população total foi estimada pela taxa de captura, construindo um modelo linear (WHO; WSPA 1990). A Figura 12 e a Tabela 16 representam o significado deste modelo. As retas obtidas para este modelo, com e sem ajuste foram $y=-0,6286 x+40,423\left(R^{2}=0,9831\right)$ e $y=-0,5569 x+40,155$ $\left(R^{2}=0,9659\right)$, respectivamente. 


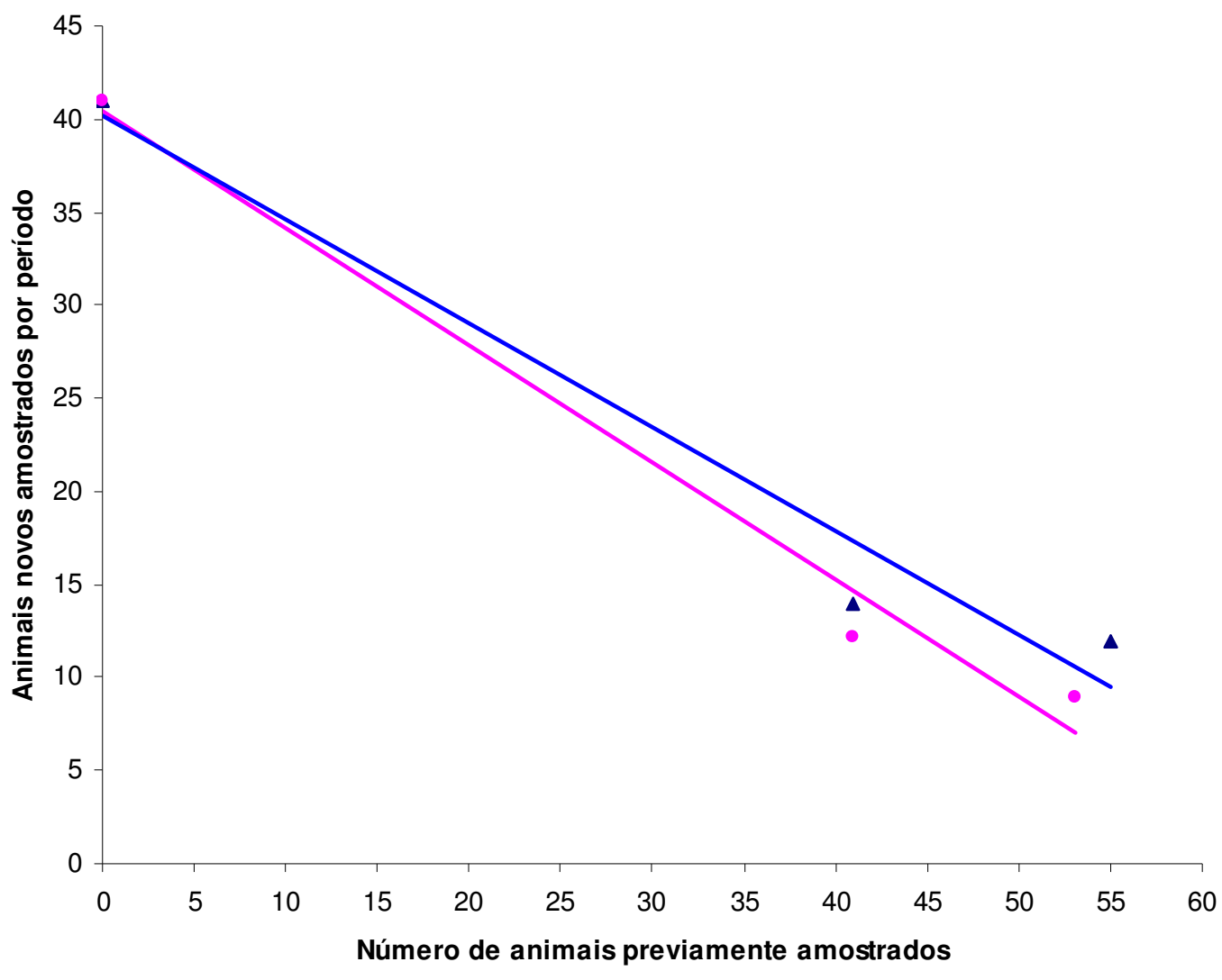

\ Sem ajuste - Com ajuste —Linear (Com ajuste) — Linear (Sem ajuste)

Figura 12: Representação do número de animais novos e os previamente capturados (com e sem ajuste) por dia, além da referida linha de tendência para os três pontos (dias amostrados). Para os pontos sem ajuste, a equação da reta é representada por y $=$ $0,5569 x+40,155\left(R^{2}=0,9659\right)$ e para os com ajuste, $y=-0,6286 x+40,423\left(R^{2}=0,9831\right)$. Substituindo a equação das retas teóricas por $\mathrm{y}=0$, obtém-se 0 valor na abscissa aproximado de 72,1 (sem correção) e de 64,3 (com correção), que corresponde ao número total teórico de animais nesta população quando não houver mais animais novos a serem amostrados.

Tabela 16: Número de animais novos e previamente amostrados por dia amostrado. O Dia $n$ representa a estimativa da população caso todos os animais fossem removidos. Em (a) estimação sem correção e (b) com correção.

(a)

\begin{tabular}{ccccc} 
& $\mathbf{3 0 / 5 / 2 0 0 6}$ & $\mathbf{6 / 6 / 2 0 0 6}$ & $\mathbf{1 3 / 6 / 2 0 0 6}$ & Dia $\mathbf{~}$ \\
\hline Previamente amostrados & 0 & 41 & 55 & $\mathbf{7 3}$ \\
Animais novos amostrados & 41 & 14 & 12 & 0 \\
\hline
\end{tabular}

(b)

\begin{tabular}{ccccc} 
& $\mathbf{3 0 / 5 / 2 0 0 6}$ & $\mathbf{6 / 6 / 2 0 0 6}$ & $\mathbf{1 3 / 6 / 2 0 0 6}$ & Dia $\mathbf{~}$ \\
\hline Previamente amostrados & 0 & 41 & 53,1 & $\mathbf{6 5}$ \\
Animais novos amostrados & 41 & 12,1 & 9,0 & 0 \\
\hline
\end{tabular}




\section{DISCUSSÃO}

Certamente podem surgir outros meios para se avaliar e estudar a probabilidade de identificação de animais por meio da fotografia, conforme a criatividade e os interesses de cada pesquisador. Além do mais, o aprimoramento da técnica depende do foco analisado. A título de exemplo, Carbone et al. (2001) e Srberk-Araújo; Chiarello (2005) avaliaram o posicionamento de armadilhas fotográficas para animais silvestres a fim de aperfeiçoar amostragem dos animais em função da alocação das câmeras. Este trabalho apresenta apenas uma sugestão de método para avaliação e aprimoramento da técnica.

\subsection{Observação das fotografias de cães do CCZ}

A $P_{(\text {parlpar efetivo })}$ e $P_{(\text {não parlnão par efetivo })}$ definem as probabilidades de um par ou não-par efetivo ser corretamente identificados pelo voluntário, respectivamente. Já $P_{(\text {parlpar para o voluntário })}$ e $P_{(\text {não parlnão par para o voluntário })}$ se referem às probabilidades de um par ou não par apontado pelo voluntário ser efetivamente um par ou não-par, respectivamente.

No geral, considerando a situação pré-exclusão de alguns voluntários, os valores de $P_{(\text {parl par efetivo })}$ e $P_{(\text {não parlnão par efetivo })}$ foram muito próximos $(98,1 \%$ e $97,1 \%$, respectivamente), sendo $0 P_{(\text {parlpar efetivo })}$ levemente superior a $P_{(n \tilde{a} o \text { parlnão par efetivo })}$. Por outro lado, a $P_{(\text {não parlnão par para o voluntário })}(99,7 \%)$ resultou em 
um valor maior que a $P_{(\text {parlpar paraovoluntário })}(83,7 \%)$, ou seja, as pessoas tenderam a ser mais convictas em diferenciar os cães (dizer que não são o mesmo animal) ao invés de identificá-los (dizer que são o mesmo animal).

Ao se considerar os resultados dessas mesmas probabilidades após a exclusão dos 12 voluntários, obteve-se como resultados $P_{\text {(par|par }}$ efetivo) $=98,6 \%, P_{\text {(não par|não par efetivo) }}=99,2 \%, P_{\text {(par|par para o voluntário) }}=95,0 \%, P_{\text {(não }}$ par|não par para o voluntário) $=99,8 \%$. Esses quatro valores de probabilidade se tornaram muito próximos após a exclusão. Com relação especificamente ao

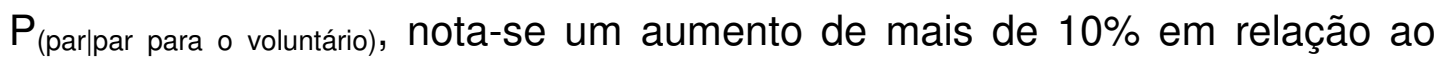
resultado pré-exclusão. Provavelmente, o processo de exclusão de voluntários eliminou aqueles que foram mais indisciplinados com relação à proposta do questionário, ou que seriam mais desatentos às características dos cães ou ao método do experimento em si (ou seja, como havia em sua maioria não-pares efetivos, os voluntários poderiam ter se condicionado a optar "automaticamente" pela resposta "não" antes de analisarem calmamente os pares de conjunto de fotos apresentados). Porém, considerando os resultados após a exclusão, quando pares e não pares efetivos são apresentados aos voluntários, esses tendem a serem identificados como tais sob uma incerteza pequena.

As causas da caracterização destes resultados não são simples e provavelmente não são únicas. Contudo, além do fato de os cães geralmente serem animais distinguíveis entre si (Hafez, 1982; WHO; WSPA, 1990; Beck, 2002), pode ter havido alguma influência da seleção de cães para a adoção (pois pode ter sido selecionado aqueles com características 
físicas individuais menos evidentes, de tal modo que apenas os voluntários incluídos pelo ponto de corte de $94 \%$ de acerto foram capazes de visualizar os detalhes que diferenciam ou identificam esses cães), ou ainda, pode ter ocorrido o fato de características peculiares de cada cão (por exemplo, genitália, padrão de manchas, coloração, pelagem e porte físico) terem sido mais bem notadas por alguns voluntários em relação a outros.

Além disso, no caso dos resultados pós-exclusão, o fato de a $P_{(\text {parlpar para ovoluntário })}$ ser o menor das probabilidades pode ser justificado também por terem sido avaliados um número maior de não-pares efetivos em relação aos pares efetivos (2366 e 364 respectivamente). Embora proporcionalmente, os erros entre $P_{(\text {parl par efetivo) }}$ e $P_{(\text {não parlnão par efetivo) }}$ sejam próximos, quantitativamente há uma diferença considerável (19 não pares efetivos avaliados foram assinalados como pares e 5 pares efetivos avaliados foram assinalados não pares). O valor de 19 indica um erro proporcionalmente maior dentro do total de pares assinalados pelos voluntários (378) se comparado com o valor de 5 entre os não pares assinalados pelos voluntários (2352). Conseqüentemente, o valor de $P_{(\text {parlpar para o voluntário })}$ foi menor que $P_{(\text {não parlnão par para o voluntario })}$.

Em termos de estudos de foto-identificação de animais, foram poucos os estudos que apresentaram um foco similar ao apresentado aqui. $O$ trabalho de Sallum (2005), em certo momento, cita que a sensibilidade da técnica fotográfica foi em torno de $60 \%$. Não foram detalhados qual o significado de sensibilidade nesse contexto, nem o método utilizado, porém, supondo que seja a probabilidade de identificar corretamente os animais, os 
resultados obtidos aqui a partir das fotografias do CCZ apresentaram valores mais altos em relação àquele. O mais provável é que as diferenças de resultados estejam concentradas sobre o método utilizado.

Não foram estudadas as probabilidades nem as concordâncias separadamente por catálogo, pois consideramos que na prática não é possível "escolher" catálogos para fotografar os animais. Sendo assim, devido a aleatoriedade no padrão das fotografias obtidas em campo, o mesmo princípio foi realizado para a avaliação dos pares de conjunto de fotografias, no qual o pareamento foi realizado confrontando diferentes catálogos entre si. Contudo, devido a diferença de qualidade entre os catálogos, é intuitivo que haja diferença ao se considerar probabilidades parciais sobre um tipo específico de combinação de catálogos.

Considerando os resultados gerais, em termos práticos, as quatro probabilidades são interessantes e têm potencial prático, já que o método clássico implica que alguma pessoa efetue a procura por animais que estiveram presentes concomitantemente nas duas amostragens por meio da observação das fotografias (WHO; WSPA, 1990) e, além disso, essa quantidade de animais é passível de ajuste utilizando estes parâmetros de probabilidade.

Em termos de concordância, isto é, índice Kappa $c c z$, no contexto geral (considerando os resultados pós-exclusão de alguns voluntários), o valor foi de $96,3 \%$, que pode ser considerado relativamente alto. Novamente, assim como já comentado, este resultado pode ter sido influenciado pelo efeito da amostragem dos cães usados como modelo ou pelo efeito do perfil do 
voluntário (ainda que este possa ser pequeno, considerando a exclusão daqueles cujos resultados foram discrepantes). Além disso, os voluntários podem ter sido influenciados pelo "cenário da foto", ou seja, ao invés de se orientarem unicamente pela imagem do cão, podem ter se direcionado por alguma característica do cenário (objetos ou pessoas) que inevitavelmente estiveram presentes concomitantemente em dois conjuntos de fotos de um mesmo cão. Todavia, houve uma tentativa de se amenizar este efeito ao se reduzir a área da foto àquela em que o cão está fotografado. Esse procedimento também auxiliou na construção do questionário on line por diminuir o tamanho da fotografia (o que permitiu maior velocidade da página do site em ser carregada para a visualização do voluntário, em termos de memória).

Entretanto, deve ser observado neste ponto que a avaliação da técnica e a obtenção dos parâmetros foram determinadas desconsiderando a probabilidade do efeito da variável tempo e da probabilidade de o animal apresentar alterações das marcas identificadoras, já que a primeira etapa deste estudo foi realizada obtendo-se catálogos fotográficos a partir de um único momento. Ou seja, todas as fotografias foram obtidas de cada cão foram obtidas em um só dia, já que haveria a probabilidade de se perder o animal por ele estar disponível para adoção.

Além disso, em nenhum momento durante este estudo, no que diz respeito à participação dos voluntários, foram avaliadas o nível de atenção deles nem a associação de seus resultados com os seus perfis. Conforme comentado anteriormente, o nível de atenção e o perfil da pessoa podem ter 
influenciado no sentido de originar resultados envolvidos por erros grosseiros, devido a observações pouco atenciosas ou mesmo pela falta de disciplina ou seriedade.

Possivelmente, este fato poderia ser amenizado repetindo-se por algumas vezes alguns pares de conjunto de fotos já previamente avaliados pelos voluntários, a fim de avaliar o quanto atento este estaria. Tomando esta sugestão por base, o fato de esses pares de conjunto de fotos do CCZ serem em sua maioria não-pares efetivos poderia estar condicionando os voluntários a optarem "automaticamente" pela resposta "não é par" antes mesmo de captarem a mensagem transmitida pela imagem das fotografias. Porém, pelos resultados obtidos, este argumento provavelmente teve uma influência baixa sobre os resultados, visto que $P_{(\text {parlpar efetivo) }}$ e $P_{\text {(não parlnão par efetivo) }}$ foram muito próximos.

Pode-se considerar também que o tamanho da amostra de cães utilizados como modelo pode ter influenciado nos resultados, visto que a variabilidade dos pares efetivos é limitada pelos cães utilizados. Ou seja, caso o número de cães utilizados como modelos fosse maior, a variabilidade fenotípica submetida em avaliação seria maior e, assim, poderíamos ter resultados diferentes.

A heterogeneidade do perfil do voluntário poderia ter influenciado no sentido de não reconhecer a validade e a importância da pesquisa, seja em termos de benefício ou desenvolvimento humano, ou pela falta de experiência sobre o procedimento desejado (observar cães). A título de exemplo, alguns fatores envolvidos no perfil da pessoa que poderiam estar 
envolvidos nos resultados obtidos são: o nível cultural, de instrução, a profissão de cada um, a disponibilidade de tempo, além do gosto e a criação por cães. Este efeito poderia ser amenizado caso o perfil do voluntário fosse padronizado (por exemplo, apenas veterinários, de certa faixa etária, que trabalham em instituições de controle animal). Neste estudo, não foi considerada a possibilidade de se efetuar esta padronização de perfis, pois se acreditou que influência desse aspecto seria pequena devido ao fato de o cão ser uma espécie possível de distinção e de identificação, conforme alguns trabalhos relataram (Beran; Frith, 1988; Daniels; Bekoff, 1989; WHO; WSPA, 1990; Pal et al., 1998b; Reichmann et al., 2000b; Beck, 2002; Sallum, 2005). Contudo, notou-se que o perfil do observador determina algum nível de influência sobre o resultado dos pareamentos. Portanto, para amenizar este efeito sobre os resultados, estabeleceu-se um ponto de corte relativo à taxa de acertos sobre os pares apresentados e excluiu-se das análises aqueles cujos resultados foram menores que o ponto de corte adotado.

\subsection{Observação das fotografias de cães obtidas a campo}

De forma paralela à análise dos resultados das observações sobre as fotografias obtidas do CCZ (padrão ouro), pode-se realizar um estudo da avaliação da $P_{(\text {par|par efetivo })}$.

No caso das fotografias dos cães da rua, diferentemente das fotos do CCZ, estas não possuem um padrão ouro absoluto. Isto é, não foi estipulado 
um "gabarito" formal indicando quais encontros correspondem ao mesmo animal. Embora essa informação pudesse ter sido obtida de maneira relativamente simples (por exemplo, conversando com os moradores locais) (Beck, 2002), ela não foi procurada, já que houve o receio de os moradores influenciarem na naturalidade da liberdade dos animais às ruas, sob a suspeita da remoção desses animais pelo serviço de controle animal municipal.

Os cães fotografados no $\mathrm{CCZ}$ encontravam-se em situação experimental, isto é, foram manejados com o uso de uma corrente extensa e dentro de um ambiente relativamente fechado. É provável que nessa situação, o comportamento dos animais frente ao processo de obtenção das fotografias ou até mesmo a atividade de se fotografar os cães nesse ambiente não foram fielmente reproduzidas em relação à situação de campo. Dessa forma, as diferenças de resultados de concordância entre as duas situações pode ter sido causada devido aos critérios e/ou hipóteses metodológicas estipuladas.

Embora os cães do CCZ utilizados como modelo sejam originários da população livre nas ruas, por estarem no canil de adoção da instituição, foram submetidos a um processo de seleção. Neste processo de seleção, os cães com o melhor estado geral aparente e de menor agressividade (determinado por critérios dos veterinários locais) são oferecidos para adoção. Este processo seletivo poderia gerar uma diferenciação entre os animais utilizados como modelos e àqueles soltos nas ruas, já que os do canil de adoção poderiam representar a parcela com características 
peculiares da população de rua, e não uma caracterização geral. Logo, em termos comparativos entre as duas situações (CCZ e rua), este pode ser um dos fatores responsáveis por possíveis distorções de resultados. Este efeito poderia ser amenizado se, ao invés do uso de cães modelo como os do CCZ, fossem utilizados cães das ruas, seja em situação autorizada pelo proprietário do animal (neste caso, tirar-se-iam as fotografias em domicílio) ou utilizando conjuntos de fotos de um mesmo encontro fotografado. Esta segunda opção foi avaliada neste trabalho.

Utilizando as fotografias de um mesmo encontro como padrão ouro de campo, foi possível estimar a $P_{(\text {parl par efetivo })}$. No geral, o valor de $P_{(\text {parlpar efetivo })}$ foi de 95,7\% (resultado considerando pós-exclusão de alguns voluntários), que foi considerado próximo do valor obtido para o mesmo parâmetro para as fotos do $\operatorname{CCZ}\left(P_{(\text {parlpar efetivo })} \mathrm{CCZ}=98,6 \%\right)$. Pelos mesmos argumentos levantados para o fato de não terem sido realizadas análises por catálogo para as probabilidades de observação das fotografias do CCZ, para esta presente situação elas também podem ser consideradas.

Assumindo que o cenário não interfere na decisão dos voluntários entre optar por ser ou não ser o mesmo animal nas fotografias, pode-se afirmar que as diferenças entre as populações das ruas do Bairro de Santa Lúcia e a dos animais do setor de adoção do CCZ são pouco significantes. Porém, é possível que nesta avaliação tenha havido influência do efeito do cenário na tomada de decisão dos voluntários. Mesmo concentrando as áreas das fotos sobre o animal e assim, excluindo-se a área excedente a fim de amenizar o efeito deste aspecto, é possível que os voluntários tenham 
conseguido optar por ser o mesmo animal nas fotografias devido a coincidência de ambiente presente em ambos os conjunto de fotos. Este viés poderia ser diminuído caso fosse utilizado algum recurso fotográfico mais refinado (por exemplo, um processador de imagem para se isolar apenas a figura do cão do resto do cenário) ou obter as fotos procurando-se sempre cenários de fundo diferentes.

Em relação a este trabalho, ambas as sugestões seriam possíveis, porém trabalhosas. A primeira opção exigiria conhecimentos técnicos sobre o software utilizado, ou, dependendo do nível de exigência, talvez até mesmo a contratação de um serviço terceirizado. Já na segunda, seria necessário que o fotografo fosse mais ágil do que o cão a fim de que a movimentação desse (ou até mesmo a fuga) não o impeça de conseguir fotografias de qualidade alta e incluindo cenários de fundo diferentes.

Vale ressaltar que apesar de as probabilidades $P_{(\text {par par efetivo) }}$ terem sido próximas tanto para as análises do $C C Z$ quanto para as da rua, ambas se referem a resultados gerais. Porém, no caso do $P_{(\text {parlpar eftivo })} \mathrm{Ccz}$, os pares avaliados nesse apresentaram (intuitivamente) uma proporção diferente de combinação de catálogos apresentados aos voluntários, se comparada ao da rua. No caso da rua, a maioria dos catálogos obtidos foi de categoria A e, portanto, a probabilidade de ser apresentados pares de combinação AxA é maior que qualquer outra combinação.

Contudo, a cronologia metodológica deste experimento partiu em primeiro lugar para a obtenção das fotografias dos cães do CCZ e em seguida, da rua. Nesse momento, não havia noções de qual seria o padrão 
mais evidente na situação prática. Logo, partiu-se para a situação maximizada, que é aquela a qual se refere a uma proporção aproximadamente equivalente de pares de catálogos apresentados. Tendo por hipótese inicial que, na rua, a obtenção das fotografias segue um padrão aleatório, e como a escolha dos pares de catálogos apresentados aos voluntários também foi aleatório, pode se assumir que os dois parâmetros ( $P_{(\text {parlpar efetivo })}$, obtido pelos cães do CCZ e os da rua) seriam equivalentes.

Não foi estudada a concordância do índice Kappa entre os resultados dos voluntários e o do pesquisador, pois foi assumido que o grau de observação dos voluntários e do pesquisador são semelhantes.

\subsection{Utilização do método de captura-recaptura fotográfica no bairro de Santa Lúcia (Ibiúna / SP)}

Considerando que foram fotografados 137 dos 150 encontros, houve um aproveitamento de $91,33 \%$, o que pode ser considerado bastante satisfatório. Entre as causas da impossibilidade de não se ter o registro fotográfico desses encontros podem ser destacados os contratempos gerais que impediram o rápido registro e a obtenção da fotografia do animal. Estes números representam que os cães fugiram do local por três vezes e entraram em residência por dez vezes. Para Sallum (2005), embora a contagem realizada no bairro de Jardim Fortaleza (Guarulhos/SP) tenha sido bem concluída, alguns pontos negativos do método foram comentados, tais como o risco de os pesquisadores sofrerem algum agravo pelos animais, a 
influência da comunidade local no sentido de impedir a captura ou recaptura dos animais e demais problemas operacionais (custo do combustível, disponibilidade de veículo e motorista). Estes aspectos também foram notados durante a execução desta pesquisa.

Para este trabalho, não houve uma tentativa imediata para que os pontos negativos fossem amenizados. Entretanto, com base nas experiências adquiridas, sugestões para que outras amostragens tenham maiores sucessos podem ser descritas. Assim como Beck (2002) descreve em seu estudo, a divulgação da pesquisa na comunidade torna-se importante, não apenas para se obter maior naturalidade sobre a movimentação dos animais (já que isso diminuiria o receio das pessoas quanto aos animais livres), mas também para se obter informações importantes sobre a dinâmica dessa população e mesmo sobre as origens desses animais.

Aconselha-se que os animais não sejam fotografados diretamente de frente e que seja respeitada uma determinada distância segura entre o fotógrafo e o animal. Essa distância poderia ser a mesma do alcance máximo do zoom da câmera utilizada.

Comparando o uso do método de marcação por fotografias com o do uso de coleiras coloridas, como o desenvolvido por Matos et al. (2002), a primeira apresenta a desvantagem de não poder possibilitar a classificação da população em estratos. Uma possível maneira de se conseguir isso por meio do método fotográfico seria fotografar e documentar cada animal domiciliado. Em seguida, comparar as fotos dos animais em vias públicas 
com os domiciliados. Entretanto, deve-se tomar cuidado com a possibilidade de se perder marcas identificadoras com o passar do tempo (McConkey, 1999). Ainda neste estudo realizado por Matos et al. (2002), o autor relata em seu trabalho que, durante a etapa de entrevista aos proprietários, alguns citaram o animal como totalmente restritos quando na verdade não o eram. Isto poderia influenciar na execução de estudos populacionais de cães soltos nas ruas, visto que haveria uma alteração da situação natural em função do receio que as pessoas da comunidade teriam em ter seus animais apreendidos.

Em um relato de caso na cidade de Lalitpur (Nepal), incluído em uma revisão de literatura de Wanderler et al. (1993), a foto-identificação, associada à marcação pelo uso de colares, estimou a taxa de perda de colar pelos cães.

Conforme citado no parágrafo anterior, para Beck (2002) a participação da comunidade nos estudos de população canina livre nas ruas é importante para se obter informações relativas à dinâmica e origens desses animais. Porém, semelhante ao descrito por Matos et al. (2002), Beck (2002) também relata que houve suspeitas sobre o seu trabalho no bairro e que isso poderia influenciar sobre a naturalidade da população canina solta no local. Inclusive, este autor detalha que utilizava roupas limpas e comuns para não chamar a atenção de que fosse alguém que trabalhava em uma instituição de controle animal. Somente após ele ter se tornado uma pessoa conhecida na comunidade é que os moradores locais se sentiram a vontade para discutir sobre a situação dos cães com ele. 
Portanto, obter a confiança da comunidade durante os estudos de campo sobre a população canina é fator fundamental para o sucesso dos resultados.

O posicionamento do animal no momento da fotografia, o tipo de pelagem e a distância foram fatores limitantes para que os registros dos cães fossem considerados ideais. Por exemplo, devido à posição do animal no momento da obtenção da fotografia e à pelagem longa de alguns deles, em 12 dos 137 encontros fotografados não foi possível de se distinguir o sexo. Tal fato é exatamente uma das desvantagens da técnica de fotoidentificação, conforme mencionado por McConkey (1999) em seu estudo sobre os Leões Marinhos da Nova Zelândia.

Não houve preocupação em tentar incluir os animais não fotografados em pareamento com os animais fotografados, pois:

- Mesmo que no formulário utilizado a campo contivesse descrições sobre a fisionomia do animal, a ausência de fotografias poderia causar identificações ou individualizações inadequadas. Ou seja, a ausência de registro fotográfico traria apenas um registro superficial do animal encontrado se comparado com os registros considerados ideais neste trabalho (formulário e fotografia);

- No caso de um animal ter sido encontrado e não fotografado, ele seria teoricamente recontado, já que estaria contido na proporção de animais que não foram amostrados em nenhum período (White et al., 1982; Amstrup et al., 2005). 
No total, foram obtidos 600 conjuntos de fotos (considerando aqueles descritos neste trabalho, entre A, B, C ou D) a partir dos 137 encontros. Assim, em média, foram obtidos 4,4 conjuntos de fotos por encontro. Em termos quantitativos, isto é bastante satisfatório, visto que ao se utilizar as os conjuntos de fotos de maneira complementar uma a outra (isto é, a visualização adquirida por um conjunto complementa o outro), as chances de se cometer um equívoco se tornaram menores.

598 dos 600 catálogos fotográficos foram baseados nos catálogos $A$, B ou C da primeira etapa deste estudo. Apenas dois deles foram fotografados seguindo o catálogo D. O catálogo A foi o protocolo mais seguido provavelmente devido à agilidade dos cães e pela necessidade de se fazer registros fotográficos rapidamente. Algumas vezes, cães menos agitados possibilitaram que fossem fotografados de uma distância menor e, assim, foi possível obter fotos mais detalhadas, os quais seguiram os catálogos B ou C. Por outro lado, o catálogo D, que fora o mais meticuloso, foi o menos seguido, devido ao pouco tempo disponível em cada encontro para se obter as fotografias. Para se obter as fotos seguindo o catálogo D, seria necessário que o animal se mantivesse estático e que durante este período o pesquisador fosse hábil o suficiente para a aquisição das fotos. Além disso, pela experiência adquirida, este catálogo mostrou ser menos prático em atividades a campo.

As informações levantadas a partir do formulário utilizado serviram principalmente para auxiliar na tomada de decisão do pesquisador sobre a análise das fotos. Para este estudo, os dados obtidos por meio desta fonte 
não foram utilizados para caracterizar profundamente a população canina estudada, pois esta atividade não faz parte dos objetivos propostos deste trabalho. Entretanto, futuramente poderão ser aproveitadas para se obter mais informações sobre os cães livres deste bairro. Nesses formulários foram descritos os endereços e os pontos de referência dos locais onde os cães foram encontrados e, devido ao fato de esses animais apresentarem hábitos territoriais (Daniels; Bekoff, 1989), auxiliaram na diferenciação e identificação de animais semelhantes (Anexos A e B).

Diferentemente do que foi realizado por Barão-Acuña (2002) e Zeh et al. (1998) as fotos consideradas de qualidade baixa não foram descartadas para a contagem da população canina livre. No caso dos cães, por apresentarem considerável variabilidade fenotípica (Hafez, 1982; WHO; WSPA, 1990, Beck, 2002) e devido às características de coloração e aspectos de pelagem, o uso de fotos de qualidade inferior poderia oferecer descrições sobre algumas características dos animais tal que ainda fosse possível identificá-los ou individualizá-los.

Comparando os resultados dos parâmetros calculados para $\mathrm{N}$ considerando os períodos e os dias como amostras (Tabela 8 e 14), foi observado que no geral, os valores de $\mathrm{N}$ obtidos considerando os dias como amostras foram mais precisas que aquelas considerando os períodos. Assim, para se diminuir o efeito de alguma influencia do período sobre a presença ou ausência de determinado animal na rua, é interessante que a coleta seja realizada durante o maior período possível. Ao se estender o período de amostragem, diminui-se a chance de não se obter o registro de 
um indivíduo devido ao horário ou período do dia. Contudo, períodos muito logos correm o risco de se confundir os animais já previamente fotografados com algum encontrado no ato. Este tipo de confusão, se não for controlada, pode levar a equívocos durante o pareamento dos encontros entre dois períodos (formação de trincas ou além, por exemplo) e também superestimar o tamanho da população calculada.

Assim conforme já comentado, o uso de um formulário específico para este levantamento de dados a campo pode auxiliar no controle dos registros dos animais fotografados, assim como no pareamento dos encontros, visto que informações não necessariamente contidas nas fotografias podem ser anotadas e utilizadas como recurso complementar (como por exemplo, endereço, visualização da genitália, de manchas ou de cicatrizes fora do momento da fotografia).

\subsection{Estimativas populacionais para a população canina diante de diversas configurações}

Um resumo dos recursos utilizados para a estimativa da população de cães do Bairro de Santa Lúcia é apresentado na Tabela 17, assim como seus valores reajustados pela $P_{(\text {parl par para o voluntário })}$ e $P_{(\text {não parlnão par para o voluntário })}$ e os respectivos limites de intervalos de confiança 95\%. 
Tabela 17: Tamanho da população de cães soltos no bairro de Santa Lucia segundo os estimadores utilizados e o respectivo intervalo de confiança $95 \%$.

\begin{tabular}{|c|c|c|c|c|c|c|c|}
\hline & & & & & \multirow{2}{*}{\multicolumn{3}{|c|}{ Com ajuste }} \\
\hline & & \multicolumn{3}{|c|}{ Sem ajuste } & & & \\
\hline & & $\mathbf{N}$ & $\begin{array}{c}\text { Limite } \\
\text { inferior } \\
\text { I.C 95\% }\end{array}$ & $\begin{array}{l}\text { Limite } \\
\text { superior } \\
\text { I.C 95\% }\end{array}$ & $\mathbf{N}$ & $\begin{array}{l}\text { Limite } \\
\text { inferior } \\
\text { I.C 95\% }\end{array}$ & $\begin{array}{l}\text { Limite } \\
\text { superior } \\
\text { I.C } 95 \%\end{array}$ \\
\hline \multirow{4}{*}{$\begin{array}{c}\text { Seis } \\
\text { amostras } \\
\text { (Perídos) }\end{array}$} & Método de Beck & 77 & - & - & 65 & - & - \\
\hline & $\begin{array}{l}\text { Modelo linear por } \\
\text { taxa de captura }\end{array}$ & 76 & - & - & 65 & - & - \\
\hline & $\begin{array}{l}\text { Estimador de } \\
\text { Pettersen }\end{array}$ & 74 & 63 & 85 & 66 & 58 & 75 \\
\hline & $\begin{array}{l}\text { Estimador de } \\
\text { Chapman }\end{array}$ & 69 & 60 & 78 & 64 & 56 & 70 \\
\hline \multirow{4}{*}{$\begin{array}{c}\text { Três } \\
\text { amostras } \\
\text { (Dias) }\end{array}$} & Método de Beck & 77 & - & - & 68 & - & - \\
\hline & $\begin{array}{l}\text { Modelo linear por } \\
\text { taxa de captura }\end{array}$ & 73 & - & - & 68 & - & - \\
\hline & $\begin{array}{l}\text { Estimador de } \\
\text { Pettersen }\end{array}$ & 70 & 61 & 78 & 64 & 57 & 71 \\
\hline & $\begin{array}{l}\text { Estimador de } \\
\text { Chapman }\end{array}$ & 69 & 61 & 77 & 63 & 57 & 70 \\
\hline
\end{tabular}

* A referência da fórmula apresentada pelo Método de Beck e do modelo de remoção por taxa de captura (WHO; WSPA, 1990) não descreve a respectiva fórmula de variância. Portanto, não é possível determinar o seu intervalo de confiança $95 \%$.

${ }^{\text {a }}$ Valores obtidos considerando as 15 estimativas calculadas.

${ }^{\mathrm{b}}$ Valores obtidos considerando as 3 estimativas calculadas.

Primeiramente, foi assumido, pela proximidade dos resultados de $P_{(\text {parlpar efetivo) }}$ dos cães do CCZ de 0,981 e de $P_{(\text {parlpar efetivo })}$ dos cães da rua de 0,957, que não há diferenças significativas entre os cães utilizados como modelos $(\mathrm{CCZ})$ e aqueles fotografados nas ruas, no que se refere às suas características físicas (isto é, seus fenótipos podem ser considerados de níveis de variabilidade semelhante). Tal fato nos permitiu utilizar os parâmetros de $P_{(\text {parl par para o voluntário) }}$ e de $P_{(\text {não parrnão par para o voluntatrio) }}$ para os cálculo de reajuste dos números de pares obtidos a cada par de período ou de dias estudado. Entretanto, foram utilizados 30 cães como modelos para o padrão ouro (CCZ), enquanto que no levantamento de dados nas ruas foram 
encontrados pelo pesquisador 67 animais ao longo dos 3 dias de estudo. Embora tenha-se assumido que os 30 cães estudados nas fotografias obtidas no CCZ sejam similares aos 67 encontrados nas ruas, o fato de se ter estudado a variabilidade de 30 cães pode, intuitivamente, sugerir algum tipo de inconsistência de resultados. Isto é, por serem amostras de tamanhos diferentes, não necessáriamente haveria o mesmo grau de variabilidade fenotípica entre esses animais e, sendo isso um fato verdadeiro, deve se tomar cautela ao se extrapolar os parâmetros utilizados do grupo de cães do CCZ para os da rua.

As estimativas tomadas como base a ótica do pesquisador geraram valores de $\mathrm{N}$ estimados e de intervalos de confiança relativamente próximos, tanto no caso das amostras relativas aos períodos quanto aos dias. Contudo, comparando os resultados obtidos pelas Tabelas 8 e 14, em que estão registradas os valores de $\mathrm{N}$ estimados por combinação de amostra (entre períodos e dias, respectivamente) e seus respectivos valores de desvio-padrão por $\mathrm{N}$ calculado, nota-se que os parâmetros calculados na Tabela 8 (relativa aos períodos) apresentaram uma variabilidade maior que a Tabela 14 (relativa aos dias).

Entretanto, considerando que as médias $\mathrm{N}$ gerais (entre todas as estimativas obtidas), considerando a situação sem e com ajuste ao número de animais encontrados em duas amostras confrontadas, tem se que 0 $\bar{N}_{\text {sem corręa } \tilde{a} o}=73$ animais (I.C. $95 \%$ de 71 e 76 animais) e $\bar{N}_{\text {com correça } \tilde{o}}=65$ animais (I.C. 95\% de 64 e 67 animais). Considerando que os intervalos de confiança a 95\% das duas médias não apresentam intervalos em comum, 
pressupõe-se que elas não sejam estatisticamente iguais. Portanto, para o método de captura-recaptura, o ajuste do número de animais coincidentes nas duas amostras estudadas pode proporcionar resultados estatisticamente diferentes da situação sem o ajuste.

Ainda, vale ressaltar que foram encontrados, pelos históricos de encontros (Tabelas 7 e 13), 67 animais distintos. Porém, a média das diversas estimativas de $\mathrm{N}$ ajustado apresentados na Tabela 18 foi 65 animais (ou seja, 2 a menos que o visualmente encontrados na prática). Essa diferença de valores, relativamente ortodoxa, é um efeito matemático sobre os valores de pares de encontros comuns em todas as estimativas feitas. Em termos gerais, a equação de ajuste (17) corrigiu o número de pares comuns em todas as combinações de amostras analisadas para um número acima daquele originalmente encontrado pelo pesquisador. Teoricamente, esse ajuste significa que os voluntários "esqueceram" ou deixaram de anotar "alguma quantidade" de par efetivo. Então, tomando as equações (1) e (2) como referência, o aumento no número de pares de encontros coincidentes na amostra ( $n_{11}$, nas equações (1) e (2), e denominado de $\mathrm{p}$ em algumas tabelas apresentadas) diminui o $\mathrm{N}$ estimado. Portanto, matematicamente, é por essa linha de raciocínio que se explica o porquê de o número médio de $\mathrm{N}$ estimado ter sido menor que o número efetivo de animais visualizados.

Embora o número de encontros fotografados por período tenha sido relativamente próximos entre as seis amostras $(\bar{x}=22,8$ encontros), pelo número de pares de encontros assinalados pelo pesquisador para cada 
combinação dois a dois entre os períodos, foi observada uma relativa variabilidade desse valor ( $S_{\text {pares }}= \pm 2,2$ pares). Tal variabilidade poderia estar associada com a dependência dos animais acessarem as ruas no período do dia amostrado e de serem encontrados durante a amostragem.

A prova U de Mann Whithney foi aplicada visando esclarecer se há alguma diferença significativa entre os resultados de $\mathrm{N}$ considerando apenas a combinação de períodos da parte da manhã e aqueles apenas da tarde. Observando a Tabela 11, em todos os casos, tanto com relação aos estimadores de Pettersen quanto o de Chapman, não houve diferença significativa (isto é, nível descritivo $<0,05$ ). Contudo, isto pode estar relacionado ao horário das amostras (08:30h às 10:30h e 12:00h às 14:00h). Caso houvesse um intervalo maior entre as amostras, ou caso a segunda amostragem fosse realizada em um horário mais próximo ao final do dia (por exemplo, 19:00h) (Beck, 2002), talvez pudesse ser observado algum indício de diferença na presence da população livre nas ruas com maior evidência.

Beck (2002) relata em seu estudo que durante o verão, os cães tiveram um pico de atividades (isto é, vistos em maior número) entre 05:00h às 08:00h e 19:00h às 22:00h, o que pode ser interpretado como uma forma de se protegerem do calor. Contudo, nos dias de temperatura mais amena, os cães puderam ser vistos durante todo o dia. Ainda, há trabalhos que relatam que o acesso dos cães às ruas poderia estar condicionado aos costumes dos proprietários. Como há pessoas que permanecem a maior parte do dia fora de casa, elas permitem que os cães saiam para 
complementar alguma necessidade antes e depois de elas saírem para as suas rotinas diárias (Beran; Frith, 1988; Lima Júnior, 1999; Beck, 2002).

Pelos resultados apresentados da Tabela 8 e considerando que 0 número de indivíduos presentes simultaneamente em um par de períodos não foi constante, presume-se que cada indivíduo permanece nas ruas do bairro por períodos variados. Ou seja, houve alguns cães que foram mais presentes durante o período da manhã e outros durante à tarde, além de alguns serem mais e outros menos presentes nas ruas no contexto geral. Possivelmente, se tivessem sido realizadas amostras em mais de um dia da semana (já que as amostragens neste trabalho foram realizadas um dia por semana), poderia ser encontrada alguma influência sobre o dia amostrado. Entretanto, não se pode descartar que, como o processo de amostragem envolveu a movimentação do pesquisador (não foi estabelecida uma posição fixa no bairro), logo, a chance de se encontrar o animal pode estar sujeita a influência do desencontro entre o pesquisador e o cão nas ruas.

Ao se comparar com os resultados da Tabela 14, referente às amostras por dia, observa-se que a variabilidade do número de encontros coincidentes por combinação de dias foi menor $\left(S_{\text {pares }}= \pm 0,6\right.$ pares). Nesse caso, como o período de amostragem foi mais amplo, teve por conseqüência a diminuição da influência do período sobre a presença ou não dos cães nas ruas. Assim, a chance de o número de cães presentes a cada dois dias concomitantemente seja constante foi maior, permitindo uma estimativa mais precisa. Entretanto, neste trabalho especificamente, o uso de dias como amostras contém a incerteza do pareamento dos encontros entre dois 
períodos (unificação de duas amostras obtidas em um mesmo dia). Por não ter existido um padrão ouro ou um "gabarito" para as fotografias obtidas nas ruas, de modo que esse pareamento descrito dentro de um mesmo dia está sujeito a incertezas.

Embora seja matematicamente possível estabelecer uma correção entre o número de cães coincidentes entre dois períodos de um mesmo dia, assim como estabelecido para as análises de estimativa de $\mathrm{N}$ considerando amostras obtidas por período, essa correção não permite estabelecer quais encontros devem ser unificados ou não. Em outras palavras, a correção apenas corrige a quantidade, mas não a qualidade. Portanto, ao se unificar os períodos, na primeira fase os encontros foram unificados sob a probabilidade de incerteza do pesquisador. Após a comparação entre os dias, os valores obtidos puderam ser reajustados. Não houve uma maneira de se obter um ajuste sobre qual o par de encontros entre as amostras comparadas que estariam corretas ou erradas.

Conforme as estimativas descritas por Soto (2003) para o município de Ibiúna, a relação cães domiciliados:habitantes é de 1:3,77 em média e $13,45 \%$ dos proprietários permitem que os animais fiquem soltos nas ruas. Além disso, tomando as informações do IBGE (2007) e da Prefeitura do Município de Ibiúna como base, a população canina domiciliada estimada para este bairro reside em torno de 225 animais.

Considerando a estimativa de 225 cães domiciliados no bairro e a de 63,3 a 67,8 animais contados nas ruas, estima-se que a relação entre cães soltos e domiciliados encontra-se entre $28,1 \%$ e $30,1 \%$. Porém, esta 
proporção não considera se esses animais livres pertençam ou não a algum proprietário ou, mesmo que tenham proprietário, possam residir em outra localidade (ou seja, em outro bairro). Além disso, há o risco de haver distorções de resultado, uma vez que se está considerando o uso de um parâmetro obtido por meio de um outro generalizado (ou seja, o uso da relação entre humanos e animais para se calcular a população canina estimada local) para se obter um resultado específico (proporção entre cães soltos e domiciliados para o bairro de Santa Lúcia). Isto é, não está sendo considerada a propagação dos erros em virtude do uso e da extrapolação de uma estimativa cujos limites de incerteza não estão sendo levados em consideração (Vuolo, 1996).

No entanto, durante a fase de levantamento de dados no bairro, notou-se que os animais mostravam estar habituados e socialmente adaptados com o meio em que se encontravam e mesmo com as pessoas da comunidade local. Em outras palavras, há fortes indícios de que os animais contados nas ruas estão contidos entre os cães de família ou de comunidade (WHO; WSPA, 1990). Esta característica notada sobre a população de cães soltos nesse bairro foi similar ao descrito por Beck (2002) em seu estudo no município de Baltimore, nos Estados Unidos. Este autor relata que muitos cães soltos são animais domiciliados que têm acesso às ruas por uma parte do dia e, provavelmente, são alimentados por seus proprietários ou por restos encontrados nas ruas.

Além disso, Beck (2002) relata que os cães tendem a serem tolerados pelos seres humanos no ambiente urbano, sendo por muitas vezes 
considerados parte da cidade. Se esse fato não fosse freqüente, provavelmente a atividade de procura por abrigo dos cães seria semelhante ao de ratos, que são conhecidos como animais repugnantes pela maioria das pessoas e por isso tendem a procurar por abrigos escondidos, como esgotos. No caso dos cães soltos observados em Santa Lúcia, é provável que esses sejam naturalmente tolerados pelos residentes e, ainda, conforme comentado anteriormente, sejam animais domiciliados pertencente a alguns moradores do bairro que permitem que tenham acesso às ruas por um período do dia.

Matos et al. apresentaram um estudo no município de Serra Azul (SP), onde se estimou que $40,8 \%$ da população era irrestrita e tinha acesso às ruas (Matos et al., 2002). Magnabosco (2006) relata em seu trabalho realizado no município de São Paulo que 2,42\% das residências amostradas cuidam de cães comunitários, sendo que desses, 70,07\% possuem pelo menos um cão em sua residência.

Sallum (2005) estimou para o bairro de Jardim Fortaleza (Guarulhos/SP) a população de cães livres nas vias públicas de 794 e de 104, para o primeiro e o segundo ano de seu estudo, respectivamente. Cita também que foi estimada uma proporção de falsos negativos ${ }^{17}$ de aproximadamente $40 \%$, fazendo com que esses números alcancem os valores de 1323 e de 145 animais. Este autor, para o primeiro ano do seu estudo, descreveu que a proporção de $35 \%$ de cães domiciliados encontrase nas vias públicas diariamente, enquanto que para o segundo ano, 5,1\%.

\footnotetext{
${ }^{17}$ Não foi definido com detalhes o significado de falso negativo no trabalho desenvolvido por Sallum (2005). Contudo, pelo contexto, é possível de se presumir que o termo se refere à probabilidade de se deixar de estipular um par de fotografias quando efetivamente o são.
} 
Esses resultados foram obtidos a partir de combinações de outros parâmetros demográficos de outros trabalhos. Contudo, quando essa proporção foi determinada com parâmetros obtidos por agentes do PSF do município sobre o bairro, resultados diferentes foram encontrados: $57 \%$ e 7,9\%, respectivamente. Este ocorrido apresenta a importância de estudos localizados para a obtenção de resultados mais precisos, uma vez que as características demográficas são heterogêneas quando comparadas uma localidade à outra, sendo que nem sempre é viável e possível considerar parâmetros generalizados para toda uma região ou população (Nunes et al., 1997; Dias, 2001; Dias et al., 2004).

Não foi possível obter informações sobre as relações médias entre número de animais por domicílio nem o de habitantes por domicílio, o que impossibilitou uma estimativa mais refinada da população canina domiciliada. Por meio deste cálculo, poderia ser estimada a parcela da população de cães domiciliados que tem acesso às ruas do bairro. Neste caso, seria possível de se presumir quanto cães, dentro daqueles estimados neste trabalho, pertenceriam ao próprio bairro e quantos seriam cães errantes.

Embora as informações obtidas por meio do formulário (utilizado durante o estudo de campo) não foram usadas para caracterizar a população em estudo, a proporção de machos e de fêmeas encontrado entre os animais amostrados é uma informação que merece atenção. Observou-se que dos 67 animais distintos encontrados nas ruas, 41 (61,20\%) foram caracterizados como machos e 26 (38,80\%) como fêmeas. Considerando os 
pressupostos para a aplicação do método (a de que os cães capturados se misturam homogeneamente ao restante da população não capturada), podese considerar que essa proporção se estende a toda população de cães soltos (White et al., 1982; Amstrup et al., 2005).

Wanderler et al. (1993) descreveu um caso de investigação populacional canino na Tunísia, onde foi relatado que os machos saiam mais das residências e estes cobriam uma área maior que as fêmeas, sendo uma média de $500 \mathrm{~m}$ entre a casa de referência e o local onde o cão foi encontrado. Ainda, nas áreas urbanas da Tunísia, a presença de cães domiciliados livres nas vias públicas urbanas foi muito maior que nas áreas rurais, o que poderia ser atribuído à densidade e à cultura da região, que permitiu que os animais completassem suas necessidades nas ruas. Este tipo de conduta permitiu que houvesse o contato entre os cães nãodomiciliados e os domiciliados, sendo de especial importância parra disseminação de zoonoses.

Em uma estimativa de tamanho populacional para cães domiciliados para o município de São Paulo, Paranhos (2002) também caracterizou esta população pela predominância de animais machos e por cerca de 17,32\% desta população ter livre acesso às ruas (dados obtidos a partir de entrevistas com os habitantes). Para este mesmo município, Magnabosco (2006) estimou que 52,8\% de cães machos em seu estudo.

Dias (2001) em seu trabalho realizado em Guarulhos (SP) também foi estimado o predomínio de machos, sendo a razão entre os gêneros para a 
população canina domiciliada calculada em torno de 1,70 machos para cada fêmea.

Os cães encontrados foram semelhantes àqueles dos outros estudos aqui citados e isto fortalece a idéia de que esses animais fotografados seriam irrestritos ou parcialmente restritos, similar ao que ocorre em outros lugares do Brasil e do mundo (Beck,1975; Larrieu et al., 1990; Larrieu et al., 1992; Wanderler et al., 1993; Paranhos, 2002; Neculqueo Cáceres, 2004; Lima Júnior, 1999), pois o estudo de Soto (2003) mostrou que os cães domiciliados foram na maioria machos $(70,1 \%)$ e adultos (82,87\%), assim como os animais visualizados no presente estudo. Além disso, apesar de a maioria dos encontros não mostrarem flagrante de cães saindo ou entrando de alguma residência, em 66 dos 150 deles foram vistos cães saindo ou entrando nelas, o que representa uma parcela considerável. As Figuras 13 e 14 apresentam alguns flagrantes de animais presentes nas ruas do bairro entrando em residências. 


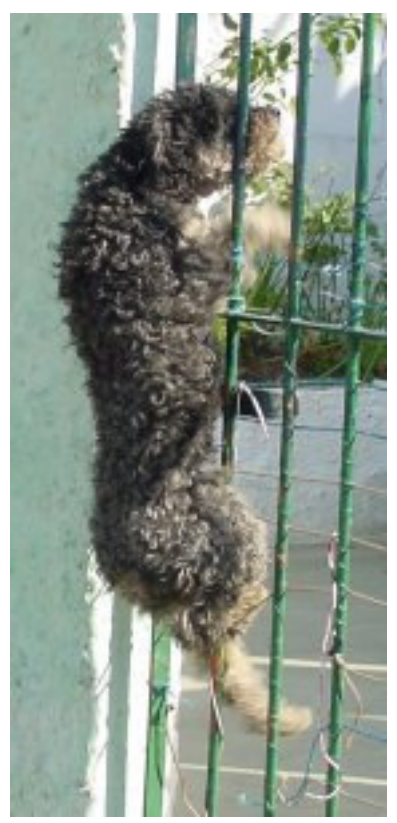

Figura 13: Flagrante de cão solto nas ruas entrando em residências durante o levantamento de dados no bairro de Santa Lúcia. Este cão conseguiu escalar o portão da residência para ter acesso às ruas.

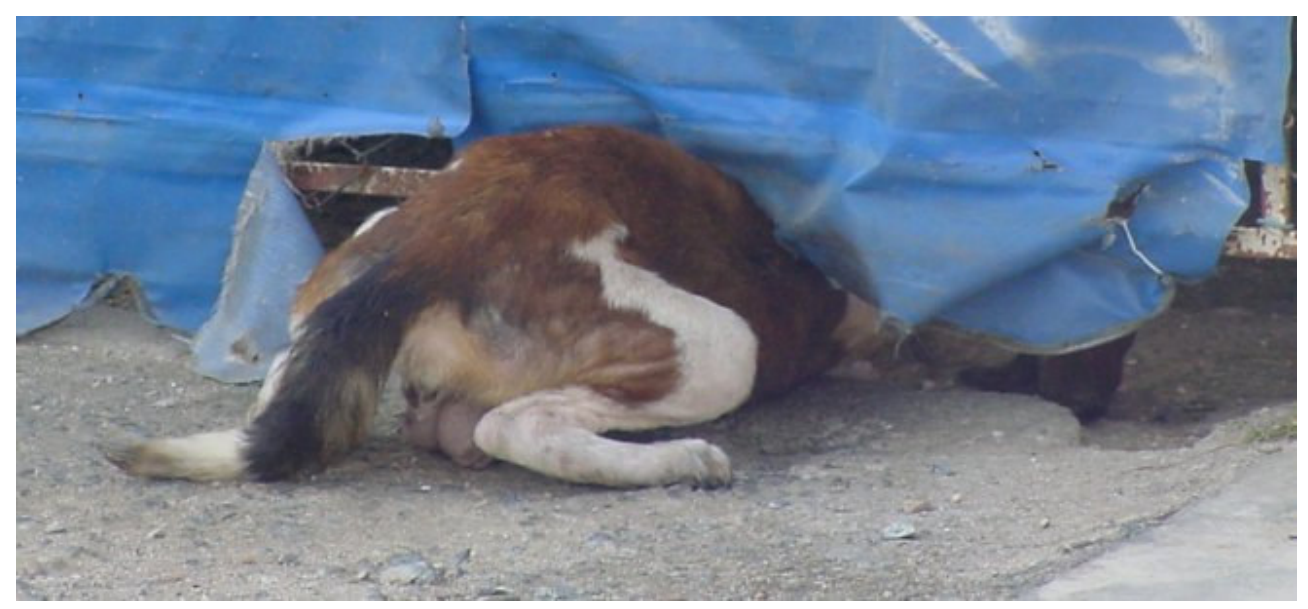

Figura 15: Flagrante de cão solto nas ruas entrando em residências durante o levantamento de dados no bairro de Santa Lúcia. Este cão teve acesso às ruas por meio de um vão entre o chão e o portão da residência.

Wandeler et al. (1993) cita um relato de caso na Tunísia entre 1986 a 1987, em que de 14 ninhadas observadas de cadelas sem proprietário na área rural apenas 2 filhotes efetivamente sobreviveram. Este fato reforça a idéia de que a população canina livre em vias públicas, em determinados 
casos, é alimentada pelo abandono e pela negligência dos proprietários aos cuidados de cães adultos, permitindo-os que tenham acesso facilitado às ruas (Feldman, 1974; Neculqueo Cáceres, 2004). No caso deste relato de caso, o sucesso da reprodução das cadelas sem dono não foi suficiente para compensar as perdas deste segmento da população. Ainda, considerando então que neste caso há um alto turnover de indivíduos (pois tanto a natalidade quanto a mortalidade são altas, mas a população de animais soltos é provavelmente mantida pela falta de consciência sobre posse responsável), as campanhas de vacinação contra raiva se tornam prejudicadas, pois, por mais que se vacinasse a população canina em massa, grande parte do seguimento de animais domiciliados se perderia.

$\mathrm{Na}$ sociedade humana, os cães são mantidos em uma população numerosa. Isto pode ser explicado devido aos processos psicológicos e de socialização. As práticas culturais influenciam o nível de restrição dos cães e o acesso aos meios de sobrevivência (Wanderler et al., 1993) e os aspectos culturais, econômicos e sociais da população humana são aqueles que vão determinar o comportamento demográfico da população canina nas áreas urbanas, independente do esforço que institucionalmente pode-se gerar (Larrieu et al., 1990). A educação sanitária e a participação consciente da população parecem ser mecanismos idôneos para diminuir a população animal, os acidentes por mordedura e a transmissão de zoonoses de importância para a saúde (Larrieu et al., 1992; Magnabosco, 2006).

Considerando que o cão é uma espécie com grande diversidade de idade de maturidade, porte, comportamento e longevidade (Hafez, 1982) e a 
possibilidade de ocorrer alterações de marcas identificadoras durante 0 estudo (McConckey, 1999), poderia ser interessante de se desenvolver estudos em que se observe o cão livre em vias públicas por um período de tempo maior que o executado no presente estudo e também para se estimar e avaliar a probabilidade de se alteração das marcas identificadoras nos cães, além de outros parâmetros populacionais, tais como probabilidade de sobrevivência, probabilidade de captura e de recaptura (White et al., 1982, Amstrup et al., 2005). Ainda, um estudo considerando-se um período de tempo maior poderia fornecer outras informações aqui pouco exploradas, como aquelas relacionadas às características vitais do animal, além de se avaliar o efeito da variável tempo sobre os registros fotográficos (ou seja, considerando alterações na fisionomia do animal ao longo do tempo).

Em linhas gerais, somando as características biológicas da espécie em estudo e pelos resultados discutidos, o método de captura-recaptura fotográfica apresentou ser exeqüível e prática (WHO; WSPA, 1990; Sallum, 2005) e os resultados obtidos foram bastante interessantes, visto que oferece uma estimativa do número de animais livres em uma determinada região e que, caso existam outros parâmetros de referência originários de trabalhos anteriores, podem auxiliar na tomada e direcionamento de decisões para as atividades de controle. 


\subsection{Sobre o método de avaliação e otimização apresentado neste trabalho}

Com relação à participação dos voluntários, o fato de o experimento ter sido oferecido pela Internet ofereceu-lhes maior comodidade e flexibilidade (em termos de disponibilidade de tempo), pois permitiu que os voluntários respondessem o questionário quando lhes fosse conveniente, o que pode ser considerado um ponto positivo do método. Contudo, podem-se apontar alguns aspectos que influenciaram na a caracterização dos resultados obtidos: (1) a ausência de meio para monitoramento dos voluntários, (2) a falta de critério de seleção de perfil dos voluntários, (3) o método em si (ou seja, caso fosse um método diferente do apresentado neste trabalho, outros resultados poderiam ter sido encontrados) e (4) os animais utilizados como modelos.

Devido ao fato de o experimento ter sido executado "on line" e por não ter havido oferecimento de acessoria imediata aos voluntários, assim como não ter sido possível monitorar a realização do teste, muitos tipos de eventos enviesadores podem acontecer, prejudicando a fidedignidade dos resultados. A título de exemplo, a falta de seriedade, ambigüidade na interpretação da pesquisa, enganos de resposta e indisposição momentânea podem ser alguns exemplos de causas explicadoras dos resultados. Para este tipo de levantamento de dados, torna-se bastante difícil de avaliar a qualidade dos resultados em função da atenção e seriedade dos voluntários. 
Sabe-se que o perfil dos voluntários deste experimento foi dos mais variados possíveis. É provável que exista algum tipo de associação entre os resultados e algum tipo específico de característica do voluntário, embora esta investigação não tenha sido feita neste trabalho. Entretanto, essa tendência de associação também poderia representar tanto qual o tipo de perfil é ou não é adequado para este tipo de estudo. Além disso, no caso da combinação de catálogos, é possível de se obter informação do quanto poderia ser o erro cometido devido à baixa qualidade da fotográfica obtida.

Conforme comentado no início dessa discussão, pode haver vários meios para se estudar os mesmos objetivos descritos neste trabalho por meio de outros métodos, conforme a criatividade do pesquisador. Aqui foi apresentado um método. Portanto, não se pode descartar a possibilidade de variações de resultados quando métodos diferentes são utilizados, já que procedimentos experimentais diferentes podem carrear ordem de incertezas diferentes dos presentes neste trabalho. Além disso, os resultados originados dos catálogos do CCZ podem ter sido outro caso outra amostra de animais tivesse sido utilizado ou se o tamanho da amostra fosse diferente de 30 indivíduos. Ou seja, se não for assumido que o grupo de animais utilizados como modelos seja representativo da população de cães de rua, a alternativa seria a de fotografar os cães (isto é, obter pelo menos duas fotografias) na rua e avaliar o pareamento considerando o próprio encontro como padrão ouro. Entretanto, nesse caso pode haver a interferência do cenário sobre a avaliação entre pares de conjunto de fotos e, também, pode haver dificuldades de se avaliar os não-pares, uma vez que ter-se-ia que 
confrontar fotografias de encontros diferentes, mas sob a incerteza de ser ou não ser o mesmo animal nesses dois encontros.

O método de avaliação e otimização apresentado neste trabalho possibilita que seja aplicável nos estudos populacionais de outras espécies animal. Além disso, tomando-se várias fotografias desses animais estudados em um único encontro é possível de se estimar uma $\mathrm{P}$ (par|par efetivo) utilizando a avaliação da combinação desses catálogos diferentes de um mesmo encontro como padrão ouro.

Tendo como referência as quatro probabilidades $\left(P_{(\text {par|par efetivo) }}, P_{\text {(não }}\right.$

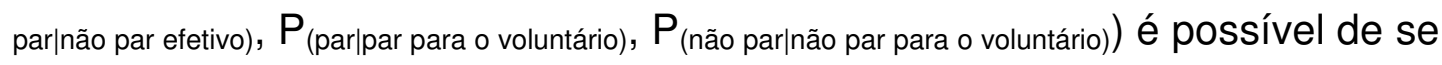
presumir o valor corrigido de encontros de animais que poderiam ter surgido em duas amostras simultaneamente e se obter um resultado mais preciso. 


\section{CONCLUSÃO}

1. No geral, as probabilidades calculadas para a técnica de fotoidentificação foram de $P$ (par|par efetivo)= 98,6\%, $P$ (não par|não par efetivo $)=99,2 \%, P($ par $\mid$ par para o voluntário $)=95,0 \%, P($ não par|não par para o voluntário)=99,8\%;

2. A população canina livre nas ruas do bairro de Santa Lúcia foi estimada (matematicamente) em torno de 65 animais (I.C. 95\% 64 a 67 animais);

3. O grau de concordância entre os voluntários e o padrão ouroccz foi estimado em Kappa $=0,963$;

4. Tendo-se em conta os parâmetros calculados que caracterizam as probabilidades de identificação e de distinção dos cães para o método de captura-recaptura fotográfica, pelos resultados obtidos e pelo uso desses parâmetros no ajuste dos valores de $\mathrm{N}$ estimado, foi possível obter resultados mais precisos que aqueles que não consideraram o ajuste dos valores do número de animais presentes concomitantemente em duas amostras.

5. Faz se necessário e de extrema importância que, se a técnica for aplicada em outras localidades, a comunidade local seja orientada e informada sobre os propósitos do estudo e sua finalidade, assim como todos os detalhes da metodologia, mesmo que isso leve a aquisição de dados enviesados. 


\section{ANEXOS}

Anexo A: Formulário utilizado para registro de dados adicionais para cada animal encontrado na segunda etapa.

$\begin{aligned} \text { Ficha no: } & \text { Data: } \_/ \frac{1}{\text { Animal Fotografado? ( ) S }} \text { Protocolo de eleição adotado: } \\ \text { ( ) N } & \text { Fugiu do local ( ) } \\ & \text { Entrou em residência ( ) } \\ & \text { Proprietário / munícipe não permitiu ( ) } \\ & \text { Outra situação: }\end{aligned}$

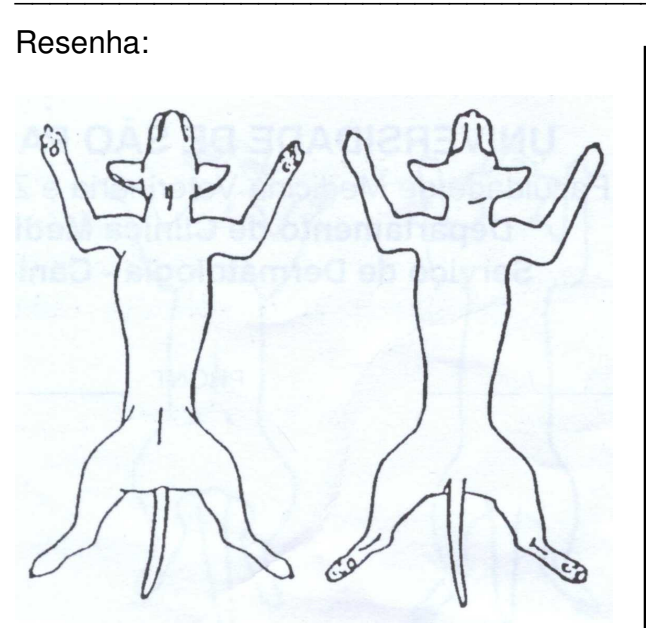
Sexo: ( ) M ( ) F
Idade aparente: ( ) Filhote
( ) Adulto

Porte: ( ) Peq. ( ) Méd. ( ) Gde.

Pelagem: ( ) Curta ( ) Méd. ( ) Longa

Cor (es) / Código (s):

Estado geral aparente: ( ) Sadio ( ) Doente

Acompanhado por outros cães? ( ) S ( ) N

Acompanhado por suposto proprietário? ( ) S ( ) N

Animal conhecido na localidade? ( )S ( )N ( )N.V.

Animal tem proprietário? ( )S ( )N ( )N.V.

Animal visto ( )saindo de e/ou ( )entrando em alguma propriedade?

( ) $\mathrm{N}$

( ) S Qual o local da propriedade?

$\begin{array}{lll}\text { () Pedro Bifano } & \text { () Benedito Domingos Vieira } & \text { () Sorocamirim } \\ \text { () Romeu G. Vieira } & \text { () Godinho Nascimento } & \text { () Murundú } \\ \text { () Flávio R. Grangeiro } & \text { () Jurupara } & \text { () Lageadinho } \\ \text { () Décio da Silva } & \text { () Mário Pires } & \text { () Rio de Una } \\ \text { Número: } & & \text { () Sorocabuçu }\end{array}$

Atitude no momento do encontro: 
Anexo B: Formulário utilizado para registro de dados adicionais para cada animal encontrado na segunda etapa (continuação).

Local de encontro:
() Pedro Bifano
() Benedito Domingos Vieira
() Sorocamirim
() Romeu G. Vieira
() Godinho Nascimento
() Murundú
() Flávio R. Grangeiro
() Jurupara
() Décio da Silva
() Mário Pires
() Lageadinho
() Rio de Una
() Sorocabuçu

Número:

Ponto de referência:

Outras características/observações: 


\section{REFERÊNCIAS}

Acha PN; Szyfres B. Zoonosis y enfermidades transmisibles comunes al hombre y a los animales. Volumen I. Bacterioses y micosis. 3a ed. Washington: Organización Panamericana de la Salud; 2001.

Amstrup SC, McDonald TL, Manly BFJ. Handbook of capture-recapture analysis. New Jersey: Princeton University Press; 2005.

Bahr SE; Morais HA. Pessoas imunocomprometidas e animais de estimação. Clínica Veterinária. 2001; 6, 30: 17-22.

Barão-Acuña L. Estimativa do tamanho da população do boto-tucuximarinho, Sotalia fluviatilis (Cetácea, Delphinidae) na região do estuário de Cananéia, São Paulo, por meio de catálogo de foto-identificação para a espécie [dissertação]. São Paulo: Instituto de biociências, Universidade de São Paulo; 2002.

Beck AM. The Public Health Implications of Urban Dogs. Am $J$ of Public Health. 1975; 65, 12: 1315-8.

Beck AM. The ecology of stray dogs - A study of free-ranging urban animals. West Lafayette, Indiana: Purde University Press; 2002.

Beran GW, Frith M. Domestic Animal Rabies Control: An Overview. Rev Infetc Dis. 1988; 10, 4: 672-7.

Brasil. Constituição, 1988. Constituição da República Federativa do Brasil: Capítulo II - Da Seguridade Social, Secção II - Da Saúde. [citado 08 janeiro 2007]. Disponível em: http://www.senado.gov.br/sf/legislacao/const/

Brasil. Senado Federal. Lei oㅡ 8080 de 19 de fevereiro de 1990. Dispõe sobre as condições para promoção, proteção e recuperação da saúde, a organização e o funcionamento dos serviços correspondentes e dá outras providências [citado em 12 fev 2007]. Disponível em:

http://www6.senado.gov.br/sicon/ExecutaPesquisaLegislacao.action

Brasil. Senado Federal. Lei no 9605 de 12 de fevereiro de 1998: artigo 32. Dispõe sobre as sanções penais e administrativas derivadas de condutas e atividades lesivas ao meio ambiente, e dá outras providências [citado 08 janeiro 2007]. Disponível em:

http://www6.senado.gov.br/sicon/ExecutaPesquisaLegislacao.action

Brasil. Senado federal. Lei $\mathrm{n}^{0} 10.406$ de 10 de janeiro de 2002. Institui o Código Civil [citado 08 janeiro 2007]. Disponível em: http://www6.senado.gov.br/sicon/ExecutaPesquisaLegislacao.action 
Campos CB. Impacto de cães (Canis familiaris) e gatos (Felis catus) errantes sobre a fauna silvestre em ambiente peri-urbano [dissertação]. Piracicaba: Escola Superior de Agricultura Luiz de Queiroz, Universidade de São Paulo; 2004.

Carbone C, Christie S, Conforti K, Coulson T, Franklin N, Ginsberg JR, Griffiths M, Holden J, Kawanishi K, Kinnaird M, Laidlaw R, Lynam A, Macdonald DW, Martyr D, McDougal C, Nath L, O'Brien T, Seidensticker J, Smith DJL, Sunquist M, Tilson R, Wan Shahruddin WN. The use of photographic rates to estimate densities of tigers and other cryptic mammals. Animal Conservation. 2001; 4: 75-9.

Cadwell BL, Smith PJ, Baughman AL. Methods for capture-recapture analysis when cases lack personal identifiers. Stat Med. 2005; 24: 2041-51.

Childs JE, Robinson LE, Sadek R, Madden A, Miranda ME, Miranda NL. Density estimates of rural dog populations and an assessment of marking methos during a rabies vaccination campaign in the Philippines. Prev Vet Med, 1998; 33: 207-18.

Ciampo LA Del, Ricco RG, Almeida CAN, Bonilha LRCM, Santos TCC. Acidentes de mordeduras de cães na infância. Rev Saude Publica. 2000; 34, 4: $411-2$.

Coeli CM, Veras RP, Coutinho E da SF. Metodologia de captura-recaptura: uma opção para a vigilância das doenças não transmissíveis na população idosa. Cad Saude Publica. 2000; 16, 4: 1071-82.

Côrtes VA, Paim GV, Alencar Filho RAA. Infestação por ancilostomídeos e toxocarídeos em cães e gatos apreendidos em vias públicas, São Paulo (Brasil). Rev Saude Publica. 1988; 22, 4: 341-3.

Daniels TJ. Conspecific scavenging by a young domestic dog. J Mammal. 1987; 68, 2: 416-8.

Daniels TJ, Bekoff M. Spatial and temporal resource use by feral and abandoned dogs. Ethology. 1989; 81: 300-12.

Davis SJM, Valla FR. Evidence for domestication of the dog 12,000 years ago in the Natufian of Israel. Nature. 1978; 276, 7: 608-10.

Dias RA. Emprego de sistemas de informação geográfica (SIG) no controle da raiva canina [dissertação]. São Paulo: Faculdade de Medicina Veterinária e Zootecnia, Universidade de São Paulo; 2001.

Dias RA, Garcia RC, Silva DFS, Amaku M, Neto JSFN, Ferreira F. Estimativa de populações canina e felina domiciliadas em zonas urbanas do Estado de São Paulo. Rev. Saude Publica. 2004; 38, 4: 565-70. 
Dicionário Aurélio Eletrônico - Século XXI [CD-ROM]. Versão 3.0. São Paulo: Editora Nova Fronteira; 1999.

Ewbank R. Animal welfare - Is an epidemiological approach possible? In: Thrusfield MV. Society for Veterinary Epidemiology and Preventive Medicine. Edinburgh: 1986. p. 92-6.

Feldmann BM. The Problem of Urban Dogs. Science. 1974; 185, 4155: 903.

Flores-Ibarra M, Estrella-Valenzuela G. Canine ecology and socioeconomic factors associated with dogs unvaccinated against rabies in a Mexican city across the US-Mexico border. Prev Vet Med, 2004; 62: 79 -87.

Forratini OP. Epidemiologia ecologia e sociedade. São Paulo: Artes Médicas: Editora da Universidade de São Paulo; 1992.

Guidorizzi, LH. Um curso de cálculo. Volume 1. $5^{\mathrm{a}}$ ed. Rio de Janeiro: LTC Editora; 2001.

Gioberchio G. A Special Relationship. Perspectives in Health - The magazine of the Pan American Health Organization. 2005; 10, 1: 24 - 9. [citado em 08 fev 2007]. Disponível em:

http://www.paho.org/English/DD/PIN/Number21_article05.htm

Goodall J. The Chimpanzees of Gombe. Patterns of Behavior. Cambridge, Massachusetts, London: The Belknap Press of Havard University Press; 1986.

Gomes LH, Almeida MF, Paranhos NT, Garcia RC, Nunes VFP, Benatti M, Cardoso, SMS. Avaliação de riscos à saúde e intervenção local associadas ao convívio com cães e gatos, Jardim Paraná, Brasilândia, São Paulo, 2003. Revista da Vigilância em Saúde Ambiental, 2004; 27-35.

Grimaldi M. A espera dos que não voltam... Animais. 2004; ano VII, no. 49: 14-5.

Hafez ESE. Reprodução animal. 4a ed. São Paulo: Manole; 1982.

IBGE - Instituto Brasileiro de Geografia e Estatística. IBGE Cidades@. [citado em 05 fev 2007]. Disponível em: http://www.ibge.gov.br/cidadesat/default.php

Ibiúna (São Paulo). Câmara Municipal. Lei no 998 de 16 de novembro de 2004. Dispõe sobre política de controle populacional de cães e gatos e dá outras providências [citado 08 janeiro 2007]. Disponível em: http://www.camaraibiuna.sp.gov.br/2004/lei_n_998.htm

Ibiúna (São Paulo). Câmara Municipal. Lei no 1.049 de 13 de maio de 2005. Disciplina a criação, propriedade, posse, guarda, uso e transporte de cães e 
gatos no Município de Ibiúna [citado 08 janeiro 2007]. Disponível em: http://www.camaraibiuna.sp.gov.br/2005/lei_n_1049.htm

Karanth KU. Estimating Tiger Panthera tigris populations from camera-trap data using capture-recapture models. Biological conservation. 1995; 71: 3338.

Kitala P, McDermott J, Kyule M, Gathuma J, Perry B, Wanderler A. Dog ecology and demography information to support the planning of rabies control in Machakos District, Kenya. Acta Trop, 2001; 78: 217 - 30.

Larrieu E, Alvarez T, Cavagion L. Aporte ao estudio de la dinamica de las poblaciones caninas. Vet. Arg. 1990; VII (64): 242-7.

Larrieu E, Alvarez T, Cavagion L, Herrasti. Dinamica de la poplacion canina de General Pico, Argentina en periodo 1986/1990. Vet. Arg. 1992; XI (88): 536-42.

Lima Júnior AD. Dinâmica populacional canina e persistência da raiva na cidade de Recife (PE), nordeste do Brasil, 1987 - 1997 [tese]. São Paulo: Faculdade de Saúde Pública, Universidade de São Paulo; 1999.

Lincoln FC. Calculating waterfowl abundance on the basis of banding returns. USDA Circular. 1930; 118: 1-4.

Luan R, Zeng G, Zhang D, Luo L, Yuan P, Liang B, Li Y. A study on methods of estimating the population size of men who have sex with men in Southwest China. Eur J Epidemiol. 2005; 20: 581-5.

McConkey SD. Photographic identification of the New Zeland sea lion: a new technique. New Zeland Journal of Marine and Freshwater Research.1999; 33:63-6.

Maciel BM, Argôlo Filho RC, Freitas ES, Kruschewsky FF, Santos BF, Rocha GD, Wetler RMC, Martins LAF. Ocorrência de sorotipos exóticos de Salmonella encontrados em case assintomáticos nos distritos do município de Ilhéus / BA - Brasil. Brazilian Journal of Veterinary Research and Animal Science. 2004; 41: 247-53.

Macpherson CNL. Human behaviour and the epidemiology of parasitic zoonoses. Int J Parasitol, 2005; 35: 1319-31.

Maffei L, Noss AJ, Cuéllar E, Rumiz DI. Ocelot (Felis pardalis) population densities, activity, and ranging bechaviour in the dry forests of eastern Bolivia: data from camera trapping. Journal of Tropical Ecology. 2005; 21: 349-53.

Magnabosco C. População domiciliada de cães e gatos em São Paulo: perfil obtido através de um inquérito domiciliar multicêntrico [dissertação]. São Paulo: Faculdade de Saúde Pública, Universidade de São Paulo; 2006. 
Massad E, Menezes RX, Silveira PSP, Ortega NRS. Métodos quantitativos em medicina. Barueri, São Paulo: Manole; 2004.

Matos MR, Alves MCGP, Reichmann MLAB, Dominguez MHS. Técnica Pasteur São Paulo para dimensionamento de população canina. Cad Saude Publica. 2002; 18 (5): 1423-8.

Matter HC, Wanderler AI, Neuenschwander BE, Harischandra LPA, Meslin FX. Study of the dog population and the rabies control activities in the Mirigama area of Sri Lanka. Acta Trop, 2000; 75: 95-108.

Meditsch RGM. O medico veterinário na construção da saúde pública: um estudo sobre o papel do profissional da clínica de pequenos animais em Florianópolis, Santa Catarina. Revista Conselho Federal de Medicina Veterinária. 2006; 12, 38: 45-58.

Miller CR, Joyce P, Waits LP. A new method for estimating the size of small populations from genetic mark-recapture data. Mol Ecol. 2005; 14: 19912005.

Neculqueo Cáceres LP. Estudo do programa de esterilizações canina e feline no Município de São Paulo, período 2001 a 2003 [dissertação]. São Paulo: Faculdade de Medicina Veterinária e Zootecnia, Universidade de São Paulo; 2004.

Nieto AG, Blanco GM, Villajos JRO. Zoonosis emergentes ligadas a animales de compañía en la comunidad de Madrid: diseño de um método para establecer prioridades em salud pública. Rev Esp Salud Publica. 2004; 78: 389-98.

Nunes CM, Martines DAM, Fikaris S, Queiroz LH. Avaliação da população canina da zona urbana do Município de Araçatuba, São Paulo, SP, Brasil. Rev Saude Publica. 1997; 31 (3): 308-9.

Pal SK, Ghosh B, Roy S. Agonistic behaviour of free-ranging dogs (Canis familiaris) in relation to season, sex and age. Applied Animal Behaviour Science. 1998a; 59: 331-48.

Pal SK, Ghosh B, Roy S. Dispersal behaviour of gree-ranging dogs (Canis familiaris) in relation to age, sex, season and dispersal distance. Applied Animal Behaviour Science. 1998b; 61: 123-32.

Palatnik-de-Sousa CB, Santos WR, França-Silva JC, Costa RTC, Reis AB, Palatnik M, Mayrink W, Genaro O. Impact of canine controlo $\mathrm{n}$ the epidemiology of canine and human visceral leishmaniasis in Brazil. Am J Trop Med Hyg. 2001; 65, 5: 510-7.

Paranhos NT. Estudo das populações canina e felina em domicilio, município de São Paulo, 2001 [dissertação]. São Paulo: Faculdade de Saúde Pública, Universidade de São Paulo; 2002. 
Patrick GR; O'Rourke KM. Dog and cat bytes: epidemiologic analyses suggest different Prevention Strategies. Public Health Rep. 1998; 113: 252-7.

Reichmann MLAB, Pinto HBF, Nunes VFP. Vacinação contra a raiva de cães e gatos. Manual Técnico do Instituto Pasteur. Número 3. São Paulo: Instituto Pasteur; 1999.

Reichmann MLAB, Sandoval MRC, Formaggia DME, Presotto D, Nunes VFP, Santos LSS, Glasser CM, Costa MAF. Orientação para projetos de Centro de Controle de Zoonoses. Manual técnico do Instituto Pasteur. Número 2. 2 ${ }^{\underline{a}}$ ed. São Paulo: Intituto Pasteur; 2000a.

Reichmann MLAB, Figueiredo ACC, Pinto HBF, Nunes VFP. Controle de populações de animais de estimação. Manual Técnico do Instituto Pasteur. Número 6. São Paulo: Instituto Pasteur; 2000b.

Saber GAF. The estimation of animal abundance and related parameters. $2^{\mathrm{a}}$ ed. London: Charles Griffin; 1982.

Sallum PC, Almeida MF, Massad E. Rabies seroprevalence of street dogs from São Paulo City, Brasil. Prev Vet Med, 2000; 44: 131-39.

Sallum PC. Avaliação do impacto de métodos de controle de populações animais errantes no município de Guarulhos - SP [Tese]. São Paulo: Faculdade de Saúde Pública, Universidade de São Paulo; 2005.

São Paulo (Município). Centro de Controle de Zoonoses. Lei 13.131 de 18 de maio de 2001. Disciplina a criação, propriedade, posse, guarda, uso e transporte de cães e gatos no Município de São Paulo [citado 08 janeiro 2007].

Disponível

em: http://portal.prefeitura.sp.gov.br/secretarias/saude/vigilancia_saude/ccz/0007 /portal/secretarias/saude/legislacao/0015

São Paulo (Estado). Leis etc. Lei no 11.977 de 25 de agosto de 2005. Institui - Código de Proteção aos Animais do Estado e dá outras providências [citado 08 janeiro 2007]. Disponível em: http://www.legislacao.sp.gov.br/legislacao/index.htm

São Paulo (Município). Centro de Controle de Zoonoses. Programa "Para Viver de Bem com os Bichos". São Paulo; 2006 [citado 08 janeiro 2007]. Disponível em: http://portal.prefeitura.sp.gov.br/secretarias/saude/vigilancia_saude/ccz/0006

Savani ESMM, Galati EAB, Camargo MCGO, D'Auria SRN, Damaceno JT, Balduino SA. Inquérito sorológico sobre leishimaniose tegumentar americana em cães errantes no Estado de São Paulo, Brasil. Rev Saude Publica. 1999; 33 (6): 629-31. 
Savani ESMM, Schimonsky B von, Camargo MCGO, D'auria SRN. Vigilância de leixhimaniose visceral americana em cães de área não endêmica, São Paulo. Rev Saude Publica. 2003; 37 (2): 260-2.

Shimozako HJ, Amaku M, Ferreira F, Dias RA, Montenegro Netto HM, Paranhos NT, Dias RB. Uso de sistemas de informação geográfica como ferramentas de auxílio na análise de casos de aapreensão de animais no município de São Paulo. Rev Ciênc Ext. 2006; 2, 2: 36-50.

Silver SC, Ostro LET, Marsh LK, Maffei L, Noss AJ, Kelly MJ, Wallace RB, Gómez H, Ayala G. The use of câmera traps for estimating jaguar Panthera onça abundance and density using capture/recapture analysis. Oryx. 2004; 38, 2: 148-54.

Slater MR.The role of veterinary epidemiology in the study of free-roaming dogs and cats. Prev Vet Med, 2001; 48: 273-86.

Soto FRM. Dinâmica populacional canina no Município de Ibiúna-SP: estudo retrospectivo de 1998 a 2002 referente a animais recolhidos, eutanasiados e adotados [dissertação]. São Paulo: Faculdade de Medicina Veterinária e Zootecnia, Universidade de São Paulo; 2003.

Southwood TRE. Ecological methods with particular reference to the study of insect populations. 2a ed. London: Chapman and Hall; 1978.

Srberk-Araujo AC, Chiarello AG. Is câmera-trapping na efficient method for surveying mammals in Neotropical forests? A case study in south-eastern Brazil. Journal of Tropical Ecology. 2005; 21: 121-5.

Thrusfield M. Epidemiologia veterinária. 2ª ed. São Paulo: ROCA; 2004.

Trolle M, Noss AJ, Lima ES. Dalponte JC. Camera trap studies of maned wolf density in the Cerrado and Pantanal of Brazil. Biodivers Conserv. 2007; 16: 1197-204.

UNESCO. Proclamação, 1978. Declaração Universal dos Direitos dos Animais, de 27 de janeiro de 1978 [citado 08 janeiro 2007]. Disponível em: http://www.forumnacional.com.br/declaracao_universal_dos_direitos_dos_an imais.pdf .

Vasconcellos MC; Barros JSL, Oliveira CS. Parasitas gastrointestinais em cães institucionalizados no Rio de Janeiro, RJ. Rev Saude Publica. 2006; 40(2): 321-3.

Vuolo, JH. Fundamentos da teoria dos erros. $2^{\underline{a}}$ ed. São Paulo: Editora Edgard Blücher LTDA; 1996.

Wanderler Al, Budde A, Kappeler A. Dog Ecology and dog rabies control. Reviews of Infectious Diseases. 1998; 10 (4): 684-8. 
Wandeler AI, Matter HC, Kappeler A, Budde A. The ecology of dogs and canine rabies: a selective review. Rev Sci Tech. 1993; 12 (1): 51-71.

White GC, Anderson DR, Burtham KP, Otis DL. Capture-recapture and removal methods for sampling closed populations. Los Alamos: Los Alamos National Laboratory; 1982.

Wong $\mathrm{CL}$, Ni I-H. Population dynamics of the feral macaques in the Kowloon Hills of Hong Kong. Am J Primatol. 2000; 50: 53-66.

World Health Organization. Basic Documents. $35^{\text {th }}$ ed. Geneva: World Health Organization; 1983.

World Health Organization, World Society for the Protection of Animals. Guidelines for dog population management. Genebra: World Health Organization; 1990.

World Health Organization. Veterinary Public Health (VPH). [citado em $08 \mathrm{fev}$ 2007]. Disponível em: http://www.who.int/zoonoses/vph/en/

Yue-Fang C; McMahon JE; Hennon DL; LaPorte RE; Coben JH. Dog Bite Incidence in the City of Pittsburgh: A Capture-Recapture Approach. Am J of Public Health. 1997; 87, 10: $1703-5$.

Zeh J, Poole D, Miller G, Koski W, Baraff, Rugh D. Survival of Bowhead Whales, Balaena mysticetus, estimated from 1981 - 1998. Photoidentfication data. Biometrics. 58:832-40. 


\section{Apêndice}

Apêndice A: Certificado de aceitação desta pesquisa pela Comissão de Ética para Análises de Projetos de Pesquisa (CAPPesq).

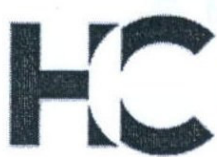

HOSPITAL DAS GLIHCAS

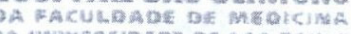

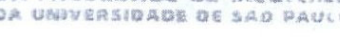

\section{APROVACEÃO}

RECEBIDO SP-10,03,06

Ass. Vanerses

A Comissão de Ética para Análise de Projetos de Pesquisa -

CAPPesq da Diretoria Clínica do Hospital das Clínicas e da Facul dade de Medicina da Universidade de São Paulo, em sessão de 08.02.06, APROVOU o Protocolo de Pesquisa $n^{\circ}$ 666/05, intitulado: "Otimização da técnica de captura-recaptura fotográfica para estimação da população canina livre em vias públicas." apresentado pela ÁREA DE FISIOPATOLOGIA EXPERIMENTAL.

Cabe ao pesquisador elaborar e apresentar à CAPPesq, os relatórios parciais e final sobre a pesquisa (Resolução do Conselho Nacional de Saúde $n^{\circ} 196$, de 10.10.1996, inciso IX. 2, letra "c").

Pesquisador(a) Responsável: Prof. Dr. Eduardo Massad Pesquisador (a) Executante: Dr. Hélio Junji Shimozako CAPPesq, 08 dé fevereiro de 2006.

Encaminhe-se à CPG-FMUSP para as devidas providéncias. S.P., $09,03,06$

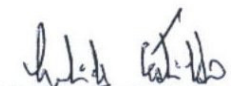

PROF. DR. EUCLIDES AYRES DE CASTILHO Presidente da Comissão de Ética para Análise de Projetos de Pesquisa

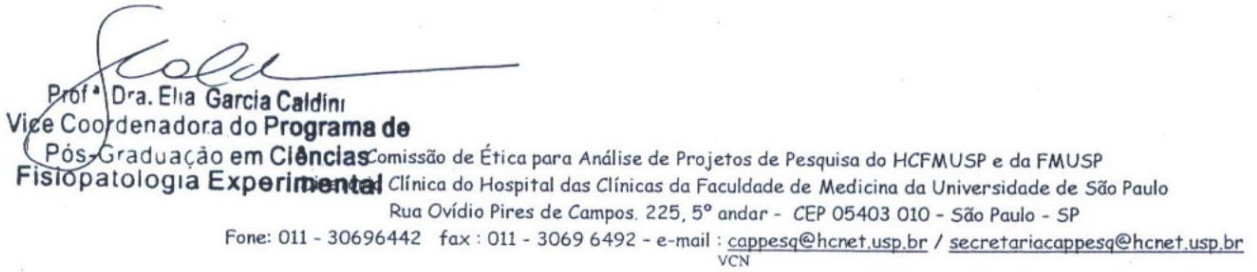


Apêndice B: Declaração de supervisão à pesquisa pelo Centro de Controle de Zoonoses do Município de São Paulo (SP).

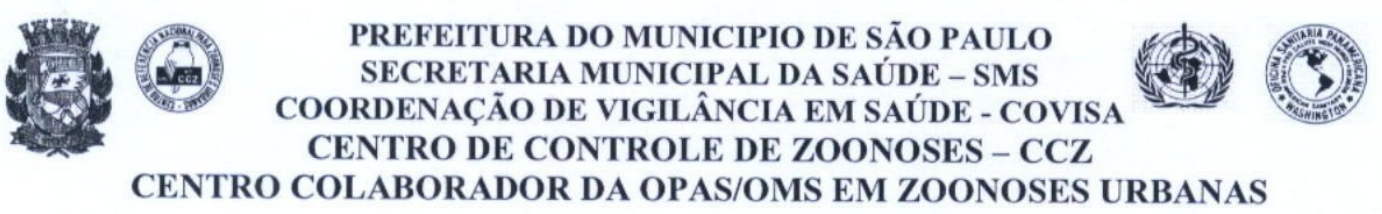

São Paulo, 12 de maio de 2005

\section{Ofício n. 178/CCZ.G/2005}

Senhor(a) Responsável,

Declaro, para os devidos fins, que o Centro de Controle de Zoonoses (CCZ) disponibilizará os dados obtidos no desenvolvimento do projeto de pesquisa visando calibrar o método de captura fotográfico de cães, objetivando a estimativa de populações caninas presentes em ruas e logradouros públicos, do aluno Helio Junji Shimozako, orientado pelo Prof. Dr. Eduardo Massad, docente do Departamento de Informática Médica desta Faculdade de Medicina da Universidade de São Paulo.

O CCZ poderá estar disponibilizando os seguintes recursos da unidade, necessários para o desenvolvimento do projeto acima citado:

- Cães pertencentes ao Setor de Adoção e, se necessário, cães dos canis coletivos, desde que sob supervisão de médico veterinário da unidade;

- Agente de Apoio (operacional), para manejo dos cães;

- Área para realização de fotos dos cães;

- Materiais necessários para o manejo dos cães, tais como cambão, coleira e guia;

- Maquina fotográfica digital

Atenciosamente,

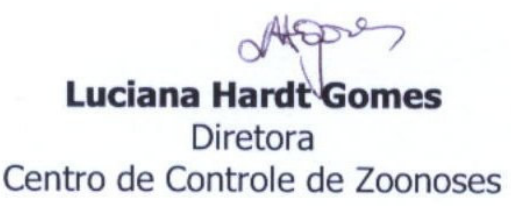


Apêndice C: Declaração de supervisão à pesquisa pelo Centro de Vigilância Sanitária e Controle de Zoonoses do Município de Ibiúna (SP).

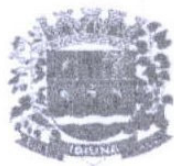

\author{
Prefeitura da Estância Turística de Ibiúna \\ Secretaria Municipal da Saúde \\ Centro de Vigilância Sanitária e Controle de Zoonoses \\ "Tereza Rodrigues de Camargo"
}

Ibiúna, 26 de janeiro de 2006.

\title{
Declaração
}

Senhor(a) Responsável,

Declaro, para os devidos fins, que o CEVISA (Centro de Vigilância Sanitária e Controle de Zoonoses "Tereza Rodrigues de Camargo") disponibilizará os dados obtidos no desenvolvimento do projeto de pesquisa titulado por Otimização da técnica de captura-recaptura fotográfica para estimação da população canina livre em vias públicas, que visa calibrar o método de captura fotográfica de cães e que objetiva a estimativa de populações caninas presentes em ruas e lugadouros públicos, do aluno Hélio Junji Shimozako, orientado pelo Prof. Dr. Eduardo Massad, docente da Disciplina de Informática Médica (DiM) desta Facuidade de Medicina da Universidade de São Paulo.

O CEVISA poderá estar disponibilizando os seguintes recursos da unidade, necessários para o desenvolvimento do projeto acima citado:

- uma viatura;

- um motorista;

- um agente de apoio

- uma câmera digital;

- um cambão para contenção dos animais (visando possíveis situações de risco).

Atenciosamente,

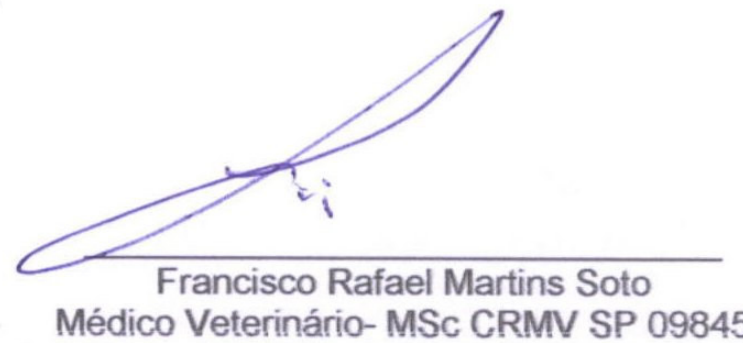

Médico Veterinário- MSc CRMV SP 09845

Diretor da Divisäo de Vigilância Sanitária e Zoonoses Municipal lbiúna - SP 